Prepared in cooperation with Colorado Springs City Engineering

Characterization of Stormflows and Wastewater Treatment-Plant Effluent Discharges on Water Quality, Suspended Sediment, and Stream Morphology for Fountain and Monument Creek Watersheds, Colorado, 1981-2006

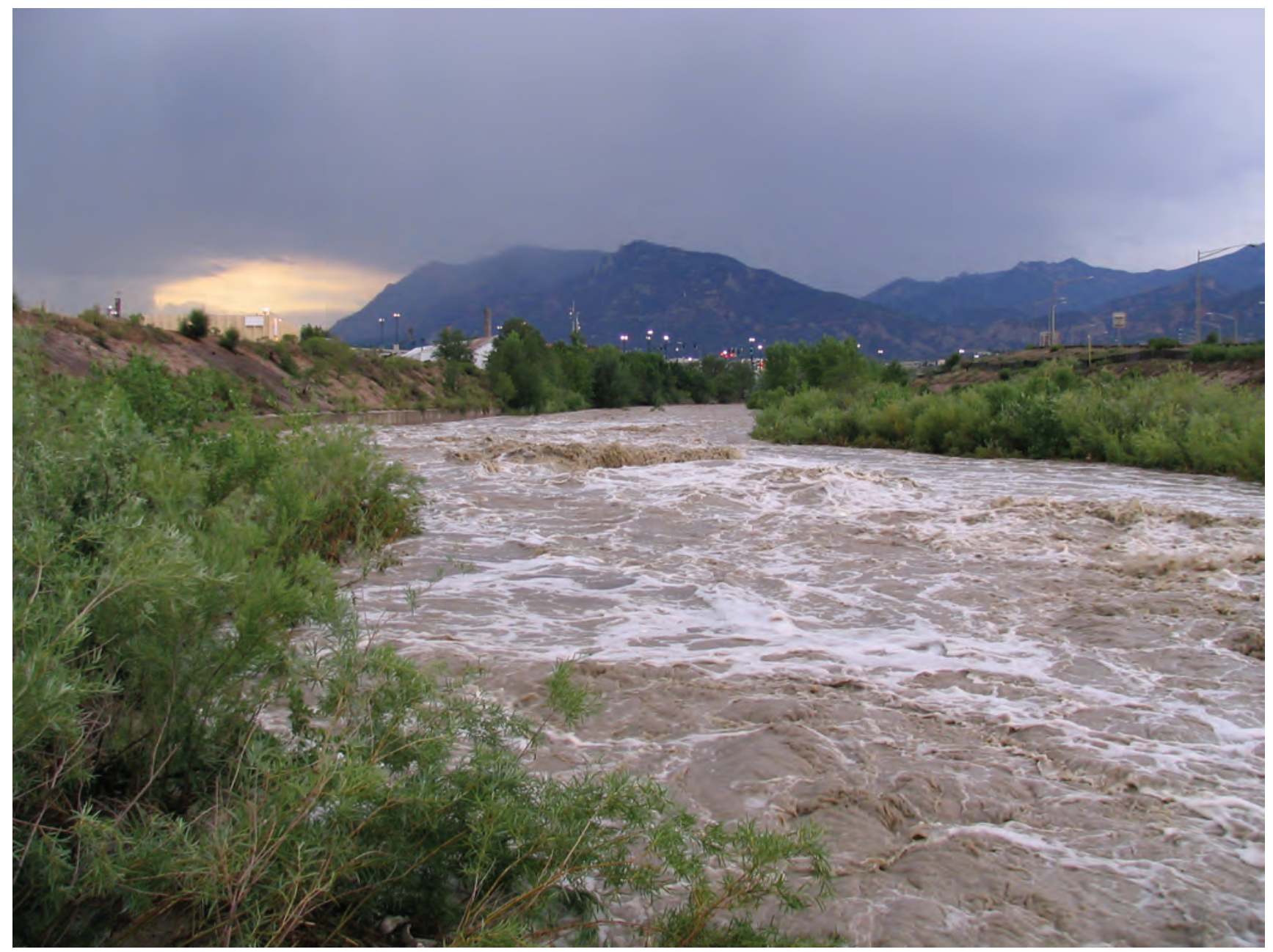

Scientific Investigations Report 2007-5104 
Cover photograph: Monument Creek, Colorado, by Robert W. Stogner, Sr. 


\section{Characterization of Stormflows and Wastewater Treatment-Plant Effluent Discharges on Water Quality, Suspended Sediment, and Stream Morphology for Fountain and Monument Creek Watersheds, Colorado, 1981-2006}

By David P. Mau, Robert W. Stogner, Sr., and Patrick Edelmann

Prepared in cooperation with Colorado Springs City Engineering

Scientific Investigations Report 2007-5104 


\section{U.S. Department of the Interior DIRK KEMPTHORNE, Secretary}

\section{U.S. Geological Survey \\ Mark D. Myers, Director}

\section{U.S. Geological Survey, Reston, Virginia: 2007}

For product and ordering information:

World Wide Web: http://www.usgs.gov/pubprod

Telephone: 1-888-ASK-USGS

For more information on the USGS--the Federal source for science about the Earth, its natural and living resources, natural hazards, and the environment:

World Wide Web: http://www.usgs.gov

Telephone: 1-888-ASK-USGS

Any use of trade, product, or firm names is for descriptive purposes only and does not imply endorsement by the U.S. Government.

Although this report is in the public domain, permission must be secured from the individual copyright owners to reproduce any copyrighted materials contained within this report.

Suggested citation:

Mau, D.P., Stogner, R.W., Sr., and Edelmann, Patrick, 2007, Characterization of stormflows and wastewater treatmentplant effluent discharges on water quality, suspended sediment, and stream morphology for Fountain and Monument Creek watersheds, Colorado, 1981-2006: U.S. Geological Survey Scientific Investigations Report 2007-5104, 76 p. 


\section{Contents}

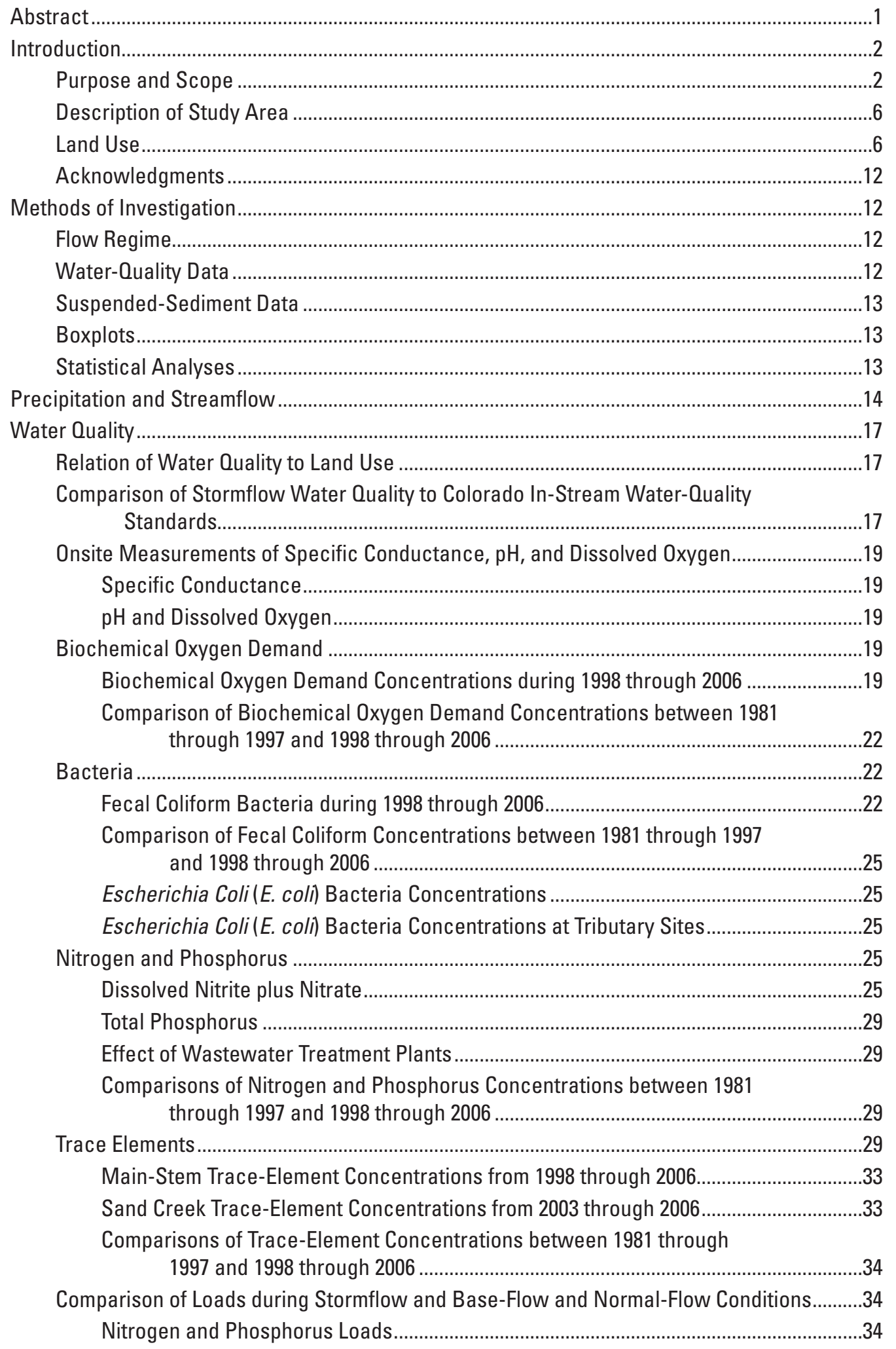


Main-Stem Nitrogen and Phosphorus Loads.............................................................34

Tributary Nitrogen and Phosphorus Loads............................................................34

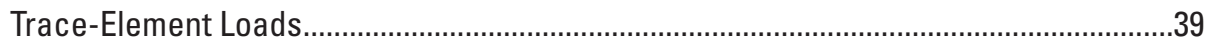

Trace-Element Loads in Upper Fountain Creek ......................................................39

Trace-Element Loads in Monument Creek Upstream from Confluence ...................39

Trace-Element Loads in Fountain Creek Downstream from Confluence.................39

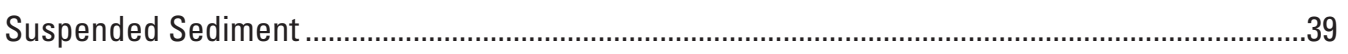

Spatial Variations in Suspended-Sediment Concentrations ..................................................42

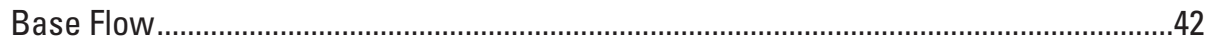

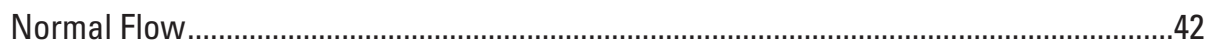

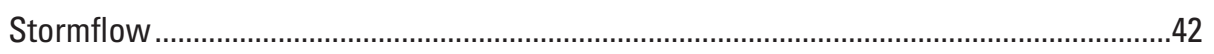

Spatial Variations in Suspended-Sediment Discharges ........................................................4

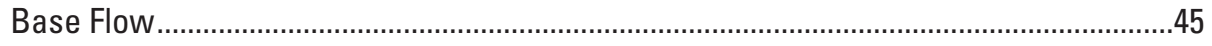

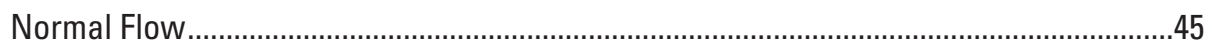

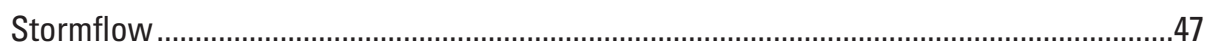

Cumulative Suspended-Sediment Discharge ………...............................................4

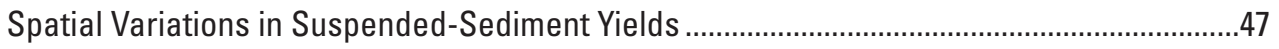

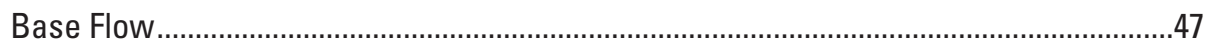

Normal Flow and Stormflow ......................................................................................52

Variations in Instantaneous Streamflow, Suspended-Sediment Concentration,

Suspended-Sediment Discharge, and Suspended-Sediment Yield at

Selected Tributaries in the Fountain and Monument Creek Watersheds.....................52

Suspended-Sediment Concentrations at Selected Tributaries in the Fountain and Monument Creek Watersheds during Normal Flow and Stormflow............52

Suspended-Sediment Discharges at Selected Tributaries in the Fountain and Monument Creek Watersheds during Normal Flow and Stormflow....................53

Suspended-Sediment Yields at Selected Tributaries in the Fountain and Monument Creek Watersheds during Normal Flow and Stormflow....................53

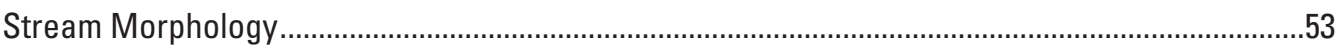

Sediment-Transport Capacity .......................................................................................57

Descriptive Assessment of Changes in Channel Morphology …………………....................57

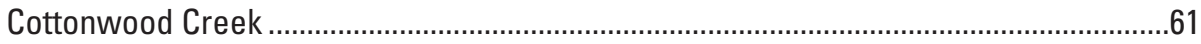

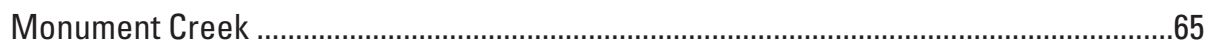

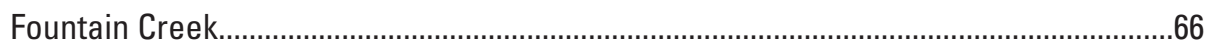

Sand Creek

Summary.

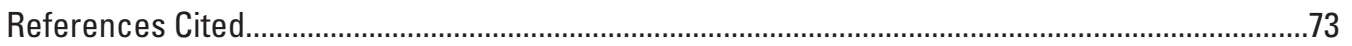




\section{Figures}

1. Map showing location of study area and sampling sites for the Fountain and Monument Creek watersheds

2. Graphs showing annual precipitation at the Colorado Springs Weather Service Office, (A) 1949 through 2006, and (B) 1981 through 2006

3-20. Boxplots showing:

3. Variations in sampled streamflow at $(A)$ main-stem sites, and $(B)$ tributary sites for base flow, normal flow, and stormflow in Fountain and Monument Creek watersheds, 1998 through 2006, and (C) comparison of sampled streamflow at selected main-stem sites between 1981 through 1997 and 1998 through 2006.

4. Variations in specific conductance at $(A)$ main-stem sites and $(B)$ tributary sites for base flow, normal flow, and stormflow in Fountain and Monument Creek watersheds, 1998 through 2006

5. Variations in $(A) \mathrm{pH},(B)$ dissolved oxygen concentrations, and $(C)$ percent saturation of dissolved oxygen at main-stem sites and Sand Creek for base flow, normal flow, and stormflow in Fountain and Monument Creek watersheds, 1998 through 2006

6. Variations in 5-day biochemical oxygen demand $\left(\mathrm{BOD}_{5}\right)$ for base flow, normal flow, and stormflow at $(A)$ main-stem sites in Fountain and Monument Creek watersheds, 1998 through 2006, $(B)$ a comparison of BOD $_{5}$ concentrations between 1981 through 1997 and 1998 through 2006, and $(C)$ temporal variations in 5-day biochemical oxygen demand $\left(\mathrm{BOD}_{5}\right)$ at site 07105530

7. Variations in fecal coliform for base flow, normal flow, and stormflow at $(A)$ main-stem sites, $(B)$ tributary sites in Fountain and Monument Creek watersheds, 1998 through 2006, and $(C)$ comparison of variations in fecal coliform between 1981 through 1997 and 1998 through 2006 ..

8. Variations in Escherichia coli (E. coli) for base flow, normal flow, and stormflow at $(A)$ main-stem sites, and $(B)$ tributary sites in Fountain and Monument Creek watersheds, 1998 through 2006

9. Variations in nitrogen and phosphorus concentrations at main-stem sites for base flow, normal flow, and stormflow in the Fountain and Monument Creek watersheds, 1998 through 2006.

10. Variations in nitrogen and phosphorus concentrations at tributary sites for base flow, normal flow, and stormflow in the Fountain and Monument Creek watersheds, 1998 through 2006

11. Variations in nitrite plus nitrate, ammonia, and phosphorus concentrations at selected sites between 1981 through 1997 and 1998 through 2006 for base flow, normal flow, and stormflow in the Fountain and Monument Creek watersheds

12. Variations in arsenic, boron, copper, lead, and manganese at main-stem sites for base flow, normal flow, and stormflow in the Fountain and Monument Creek watersheds, 1998 through 2006

13. Variations in nickel, selenium and zinc at main-stem sites for base flow, normal flow, and stormflow in the Fountain and Monument Creek watersheds, 1998 through 2006 
14. Variations in boron, copper, lead, and manganese concentrations between 1981 through 1997 and 1998 through 2006 at selected sites for base flow, normal flow, and stormflow in the Fountain and Monument Creek watersheds.

15. Variations in nickel, selenium, and zinc concentrations between 1981 through 1997 and 1998 through 2006 at selected main-stem sites for base flow, normal flow, and stormflow in the Fountain and Monument Creek watersheds.

16. Variations in nitrogen and phosphorus loads at main-stem sites for base flow, normal flow, and stormflow in the Fountain and Monument Creek watersheds, 1998 through 2006.

17. Variations in nitrogen and phosphorus loads at tributary sites for base flow, normal flow, and stormflow in the Fountain and Monument Creek watersheds, 1998 through 2006.

18. Variations in streamflow, arsenic, boron, copper, and lead loads at main-stem sites for base flow, normal flow, and stormflow in the Fountain and Monument Creek watersheds, 1998 through 2006.

19. Variations in manganese, nickel, selenium, and zinc loads at main-stem sites for base flow, normal flow, and stormflow in the Fountain and Monument Creek watersheds, 1998 through 2006

20. Variations in $(A)$ suspended-sediment concentration, $(B)$ suspendedsediment discharge, and $(C)$ suspended-sediment yield for base flow, normal flow, and stormflow at selected main-stem and tributary sites in Fountain and Monument Creek watersheds,...

21-25. Maps showing:

21. Cumulative suspended-sediment discharge in the Fountain and Monument Creek watersheds, 1998 through 2001

22. Cumulative suspended-sediment discharge in the Fountain and Monument Creek watersheds, 2002 through 2005.

23. Variations in suspended-sediment concentration during normal flow and stormflow at selected tributaries in the Fountain and Monument Creek watersheds.

24. Variations in suspended-sediment discharge during normal flow and stormflow at selected tributaries in the Fountain and Monument Creek watersheds

25. Variations in suspended-sediment yield during normal flow and stormflow at selected tributaries in Fountain and Monument Creek watersheds

26. Computation of cross-section sediment area and reach sediment volume.

27-33. Graphs showing:

27. Change in minimum streambed altitude at cross sections along selected reaches of Cottonwood Creek near sites 07103977 (upper_CoCr), 07103980 (middle_CoCr), 07103985 (TbCo), and 07103990 (lower_CoCr), October 1999 through October 2005

28. Cumulative change in volume of sediments of selected reaches of Cottonwood Creek near sites 07103977 (upper_CoCr), 07103980 (middle_CoCr), 07103985 (TbCo), and 07103990 (lower_CoCr), 1999 through 2005

29. Change in minimum streambed altitude at cross sections along a reach of Monument Creek near site 07103970 (MoCr_Woodmen), October 2000 through October 2005. 
30. Cumulative change in volume of sediments of a reach of Monument

Creek near site 07103970 (MoCr_Woodmen), 2000 through 2005

31. Change in minimum streambed altitude at cross sections along selected reaches of Fountain Creek near sites 07103700 (FoCr_Manitou) and 07105800 (FoCr_Security), October 1999 through October 2005

32. Cumulative change in volume of sediments of selected reaches of Fountain Creek near site 07103700 (FoCr_Manitou) and 07105800 (FoCr_Security), 1999 through 2005

33. Change in minimum streambed altitude at cross sections along a reach of Sand Creek near site 07105600 (SaCr), October 2003 through October 2005.

\section{Tables}

1. Selected surface-water sites in the Fountain and Monument Creek watersheds, and biological properties, water-quality constituents and suspended sediment measured or analyzed, and channel geometry surveys, 1981 through 2006.

2. Land uses and estimated total impervious area for the Fountain and Monument Creek watersheds in El Paso County, Colorado, 1997, 2001, and 2005.

3. Imperviousness coefficients for land-use categories and subcategories in the Fountain and Monument Creek watersheds.

4. Correlations between various land uses and physical properties and selected water-quality constituents for sites in the Fountain and Monument Creek watersheds, 1998 through 2005

5. Median suspended-sediment concentration during base flow, normal flow, and stormflow in the Fountain and Monument Creek watersheds, and p-values of Mann-Whitney test of significance of spatial variations in suspended-sediment concentrations.

6. Median suspended-sediment discharge during base flow, normal flow, and stormflow in the Fountain and Monument Creek watersheds, and p-values of Mann-Whitney test of significance of spatial variations in suspended-sediment discharge

7. Cumulative suspended-sediment discharge in the Fountain and Monument Creek watersheds, annually between April 1 and September 30, 1998, through 2005

8. Median suspended-sediment yield during base flow, normal flow, and stormflow in the Fountain and Monument Creek watersheds, and p-values of MannWhitney test of significance of spatial variations in suspended-sediment yields ..........51

9. Particle-size distribution for bed material at sites in the Fountain and Monument Creek watersheds based on pebble counts measured between 1998 and 2005

10. Range in particle size of bed material, in millimeters, at threshold of movement for upper and lower limits of transport of coarse materials based on minimum and maximum measured streamflow in the Fountain and Monument Creek watersheds.

11. Change in minimum bed altitude, cross-section sediment area, and estimated mass of sediment eroded or deposited at selected cross sections in the Fountain and Monument Creek watersheds, 1999 through 2005

12. Estimated mass of sediment eroded or deposited from selected reaches of Fountain, Monument, Cottonwood, and Sand Creeks, 1999 through 2005 


\section{Conversion Factors and Datums}

Inch/Pound to SI

\begin{tabular}{lcl}
\hline Multiply & By & To obtain \\
\hline inch & Length & \\
inch & 2.54 & centimeter $(\mathrm{cm})$ \\
foot $(\mathrm{ft})$ & 25.4 & millimeter $(\mathrm{mm})$ \\
mile $(\mathrm{mi})$ & .3048 & meter $(\mathrm{m})$ \\
\hline & 1.609 & kilometer $(\mathrm{km})$ \\
\hline acre & Area & \\
square foot $\left(\mathrm{ft}^{2}\right)$ & 4,047 & square meter $\left(\mathrm{m}^{2}\right)$ \\
square foot $\left(\mathrm{ft}^{2}\right)$ & 929.0 & square centimeter $\left(\mathrm{cm}^{2}\right)$ \\
square mile $\left(\mathrm{mi}^{2}\right)$ & .09290 & square meter $\left(\mathrm{m}^{2}\right)$ \\
\hline & 2.590 & square kilometer $\left(\mathrm{km}^{2}\right)$ \\
\hline cubic foot $\left(\mathrm{ft}^{3}\right)$ & Volume & \\
\hline & 0.02832 & cubic meter $\left(\mathrm{m}^{3}\right)$ \\
\hline cubic foot per second $\left(\mathrm{ft}^{3} / \mathrm{s}\right)$ & Flow rate & \\
\hline & 0.02832 & cubic meter per second $\left(\mathrm{m}^{3} / \mathrm{s}\right)$ \\
\hline pound, avoirdupois $(\mathrm{lb})$ & Mass & kilogram $(\mathrm{kg})$ \\
ton per day $($ ton $/ \mathrm{d})$ & 0.4536 & metric ton per $\mathrm{year}$ \\
ton per year $(\mathrm{ton} / \mathrm{yr})$ & .9072 & .9072 \\
\hline
\end{tabular}

Temperature in degrees Celsius $\left({ }^{\circ} \mathrm{C}\right)$ may be converted to degrees Fahrenheit $\left({ }^{\circ} \mathrm{F}\right)$ as follows:

${ }^{\circ} \mathrm{F}=\left(1.8 \times^{\circ} \mathrm{C}\right)+32$

Temperature in degrees Fahrenheit $\left({ }^{\circ} \mathrm{F}\right)$ may be converted to degrees Celsius $\left({ }^{\circ} \mathrm{C}\right)$ as follows:

$$
{ }^{\circ} \mathrm{C}=\left({ }^{\circ} \mathrm{F}-32\right) / 1.8
$$

Vertical coordinate information is referenced to the "North American Vertical Datum of 1988 (NAVD 88)."

Horizontal coordinate information is referenced to the "North American Datum of 1983 (NAD 83)."

Altitude, as used in this report, refers to distance above the vertical datum.

Specific conductance is given in microsiemens per centimeter at 25 degrees Celsius $(\mu \mathrm{S} / \mathrm{cm}$ at $\left.25^{\circ} \mathrm{C}\right)$.

Concentrations of chemical constituents in water are given either in milligrams per liter (mg/L) or micrograms per liter ( $\mu \mathrm{g} / \mathrm{L})$. 


\section{Abbreviations and initialisms used in this report:}

\begin{tabular}{|c|c|}
\hline $\mathrm{ft}^{3} / \mathrm{s}$ & cubic feet per second \\
\hline $\mathrm{mg} / \mathrm{L}$ & milligrams per liter \\
\hline$\mu \mathrm{g} / \mathrm{L}$ & micrograms per liter \\
\hline $\mathrm{col} / 100 \mathrm{~mL}$ & colonies per 100 milliliters \\
\hline$\mu \mathrm{S} / \mathrm{cm}$ & microsiemens per centimeter at 25 degrees Celsius \\
\hline $\mathrm{mm}$ & millimeter \\
\hline $\mathrm{mL}$ & milliliter \\
\hline $\mathrm{ft}$ & feet \\
\hline $\mathrm{ft}^{2}$ & square foot \\
\hline $\mathrm{ft}^{3}$ & cubic foot \\
\hline $\mathrm{lb} / \mathrm{ft}^{3}$ & pounds per cubic foot \\
\hline $\mathrm{mi}^{2}$ & square mile \\
\hline tons/d & tons per day \\
\hline tons $/ \mathrm{d} / \mathrm{mi}^{2}$ & tons per day per square mile \\
\hline \multicolumn{2}{|c|}{ Initialisms used in this report: } \\
\hline CDPHE & Colorado Department of Public Health and Environment \\
\hline CSE & Colorado Springs Engineering \\
\hline CSU & Colorado Springs Utilities \\
\hline GIS & Geographic Information System \\
\hline NWIS & National Water Information System \\
\hline NWQL & U.S. Geological Survey National Water Quality Laboratory \\
\hline USEPA & U.S. Environmental Protection Agency \\
\hline USGS & U.S. Geological Survey \\
\hline VCUP & Colorado Voluntary Cleanup Program \\
\hline WSO & Colorado Springs Weather Service Office \\
\hline
\end{tabular}




\title{
Characterization of Stormflows and Wastewater Treatment-Plant Effluent Discharges on Water Quality, Suspended Sediment, and Stream Morphology for Fountain and Monument Creek Watersheds, Colorado, 1981-2006
}

\author{
By David P. Mau, Robert W. Stogner, Sr., and Patrick Edelmann
}

\section{Abstract}

In 1998, the U.S. Geological Survey, in cooperation with Colorado Springs City Engineering, began a study of the Fountain and Monument Creek watersheds to characterize water quality and suspended-sediment conditions in the watershed for different flow regimes, with an emphasis on characterizing water quality during storm runoff. Waterquality and suspended-sediment samples were collected in the Fountain and Monument Creek watersheds from 1981 through 2006 to evaluate the effects of stormflows and wastewatertreatment effluent on Fountain and Monument Creeks in the Colorado Springs, Colorado, area. Water-quality data were collected at 11 sites between 1981 and 2001, and 14 tributary sites were added in 2003 to increase spatial coverage and characterize water quality throughout the watersheds. Suspended-sediment samples collected daily at 7 sites from 1998 through 2001, 6 sites daily from 2003 through 2006, and 13 tributary sites intermittently from 2003 through 2006 were used to evaluate the effects of stormflow on suspendedsediment concentrations, discharges, and yields. Data were separated into three flow regimes: base flow, normal flow, and stormflow.

Stormflow concentrations from 1998 through 2006 were compared to Colorado acute instream standards and, with the exception of a few isolated cases, did not exceed water-quality standards for inorganic constituents that were analyzed. However, stormflow concentrations of both fecal coliform and Escherichia coli (E. coli) frequently exceeded waterquality standards during 1998 through 2006 on main-stem and tributary sites by more than an order of magnitude. There were two sites on Cottonwood Creek, a tributary to Monument Creek, with elevated concentrations of dissolved nitrite plus nitrate: site 07103985 ( $\mathrm{TbCr}$ ), a tributary to Cottonwood Creek and site 07103990 (lower_CoCr), downstream from site 07103985 ( $\mathrm{TbCr}$ ), and near the confluence with Monument Creek. During base-flow and normal-flow conditions, the median concentrations of dissolved nitrite plus nitrate ranged from 5.1 to $6.1 \mathrm{mg} / \mathrm{L}$ and were 4 to 7 times larger than concentrations at the nearest upstream site on Monument Creek, site 07103970 (MoCr_Woodmen). The source of these larger dissolved nitrite plus nitrate concentrations has not been identified, but the fact that all measurements had elevated dissolved nitrite plus nitrate concentrations indicates a relatively constant source. Most stormflow concentrations of dissolved trace elements were smaller than concentrations from base-flow or normal-flow samples. However, median concentrations of total arsenic, copper, lead, manganese, nickel, and zinc generally were much larger during periods of stormflow than during base flow or normal flow. Concentrations of dissolved and total copper, total manganese, total nickel, dissolved and total selenium, and dissolved and total zinc ranged from 3 to 27 times larger at site 07103707 (FoCr_8th) than site 07103700 (FoCr_Manitou) during base flow, indicating a large source of trace elements between these two sites. Both of these sites are located on Fountain Creek, upstream from the confluence with Monument Creek. The likely source area is Gold Hill Mesa, a former tailings pile for a gold refinery located just upstream from the confluence with Monument Creek, and upstream from site 07103707 (FoCr_8th). Farther downstream in Fountain Creek, stormflow samples for total copper, manganese, lead, nickel, and zinc were larger at the downstream site near the city of Security, site 07105800 (FoCr_Security), than at the upstream site near Janitell Road, site 07105530 (FoCr_Janitell), compared with other mainstem sites and indicated a relatively large source of these metals between the two sites. Nitrogen, phosphorus, and traceelement loads substantially increased during stormflow.

Suspended-sediment concentrations, discharges, and yields associated with stormflow were significantly larger than those associated with normal flow. The April through October cumulative suspended-sediment discharges and streamflows were largest in 1999 and smallest in 2002. Although large 
spatial variations in suspended-sediment yields occurred during normal flows, the suspended-sediment yields associated with stormflow generally were more than 10 times larger than the suspended-sediment yields that occurred during normal flow. The largest suspended-sediment yields occurred at sites on streams located in the Colorado Piedmont that drain to Fountain and Monument Creeks from the east.

Minimum streamflows at all sites have the capacity to transport coarse sand and gravel, and maximum streamflows at some sites have the capacity to transport coarse gravel to cobble-size material. Channel downcutting is the predominant channel-forming process. Wastewater treatment-plant discharge increased streamflow and transport capacity, resulting in a shift in median bed-material size from fine to medium gravel.

\section{Introduction}

Fountain Creek is a tributary of the Arkansas River, draining a 926- $\mathrm{mi}^{2}$ area that includes portions of El Paso, Teller, and Pueblo Counties. Monument Creek is a major tributary to Fountain Creek, draining $235 \mathrm{mi}^{2}$. The population of the metropolitan areas in and around Colorado Springs within the Fountain Creek watershed has increased rapidly between 1950 and 2006. Accompanying the increase in population in the Fountain Creek watershed have been considerable changes in land use and water use. In addition, the volume of treated municipal waste return flows discharged to Fountain and Monument Creeks has increased with population. Information is needed on water quality and stream morphology of Fountain and Monument Creeks to evaluate stream health and changes with time related to population increase within the watersheds. In addition, the information can be used to satisfy water-quality permit requirements for the City of Colorado Springs (City of Colorado Springs, 1997).

In 1998, the U.S. Geological Survey, in cooperation with Colorado Springs City Engineering, began a study of the Fountain and Monument Creek watersheds (fig. 1) to characterize water quality and suspended-sediment conditions in the watershed for different flow regimes, with an emphasis on characterizing water quality during storm runoff. The scope of the study also included evaluating changes in water quality, suspended sediment, and channel morphology and to the extent possible, evaluated the effects of wastewater treatment-plant operations on water quality and suspended sediment. Historical (pre-1998) water-quality data and channel-morphology data form a baseline for comparison to data collected during the post-1997 period (1998-2006). These two periods were selected to allow comparison of the pre-permit period (1981 through 1997) to the years that have had water-quality permit requirements (1998 through 2006) (City of Colorado Springs, 1997). The year 1981 was chosen because laboratory analytical methods changed in 1980 for many water-quality constituents and data prior to that year would be incomparable to post-1981 data.

\section{Purpose and Scope}

This report describes a characterization of stormflows and wastewater treatment-plant effluent discharges on water quality, suspended sediment, and stream morphology of Fountain and Monument Creek watersheds. More specifically the report (1) provides a comparison of water-quality concentrations for base flow, normal flow, and stormflow; (2) compares water quality of stormflow for 1981 through 1997 and 1998 through 2006; (3) compares water-quality concentrations of stormflow to Colorado acute instream water-quality standards; (4) characterizes water-quality loads for base flow, normal flow, and stormflow; (5) evaluates suspended-sediment concentrations and loads for base flow, normal flow, and stormflow; (6) describes the sediment transport capacity of selected reaches of Fountain, Monument, Cottonwood, and Sand Creeks; and (7) describes changes in morphology of selected reaches and cross sections of Fountain, Monument, Cottonwood, and Sand Creeks.

Water-quality samples were collected from seven mainstem sites: five on Fountain Creek and two on Monument Creek (table 1). Water-quality samples were classified into two groups: routine and storm. Routine water-quality sampling frequency was reduced from six samples per year (1998 through 2002) to four samples per year (2003 through 2006). Routine water-quality samples were collected in February, May, July, and October. Routine samples were collected at scheduled times with little regard for hydrologic conditions. Therefore, routine samples collected during May and July could also be considered storm samples. Storm samples specifically targeted conditions during stormflow. Stormflow samples were collected annually between April 1 and September 30. The frequency of storm sampling was reduced from four samples per year (1998 through 2002) to two samples per year during 2003 through 2006. Water-quality samples also were collected on selected tributaries to Fountain and Monument Creeks. Three sites on Cottonwood Creek sampled during 1998 through 2002 were supplemented with 10 sites on 7 additional tributaries during 2003 through 2006. The additional sites included two sites on Kettle Creek, one site on Pine Creek, one site on North Rockrimmon Creek, two sites on Mesa Creek, one site on an unnamed tributary, two sites on Bear Creek, and one site on Sand Creek. These sites were added to better characterize variations in water quality and suspended sediment during nonstorm and storm periods. Two routine water-quality samples during normal flow were collected annually, one time each in June and October. One storm sample was collected from each tributary between April 1 and September 30. The sampling routine for Sand Creek was different from the other tributary sites. Two routine water-quality samples were collected in March and July, and two storm samples were collected between April 1 and September 30 . 


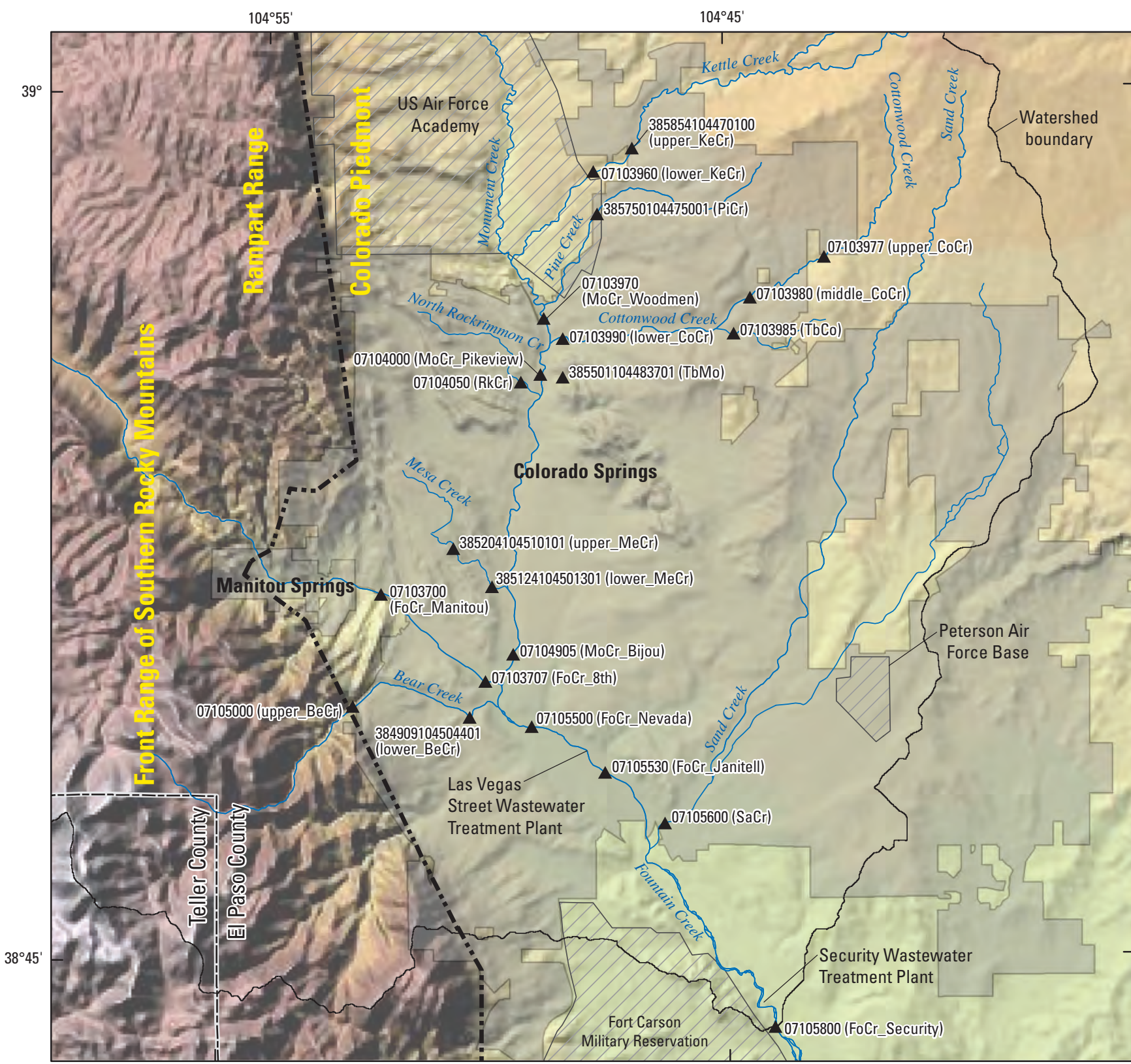

Base from U.S. Geological Survey

Albers Equal-Area Conic projection

Standard parallels $37^{\circ} 30^{\prime} \mathrm{N}$ and $40^{\circ} 30^{\prime} \mathrm{N}$

Central meridian $105^{\circ} 30^{\prime} \mathrm{W}$
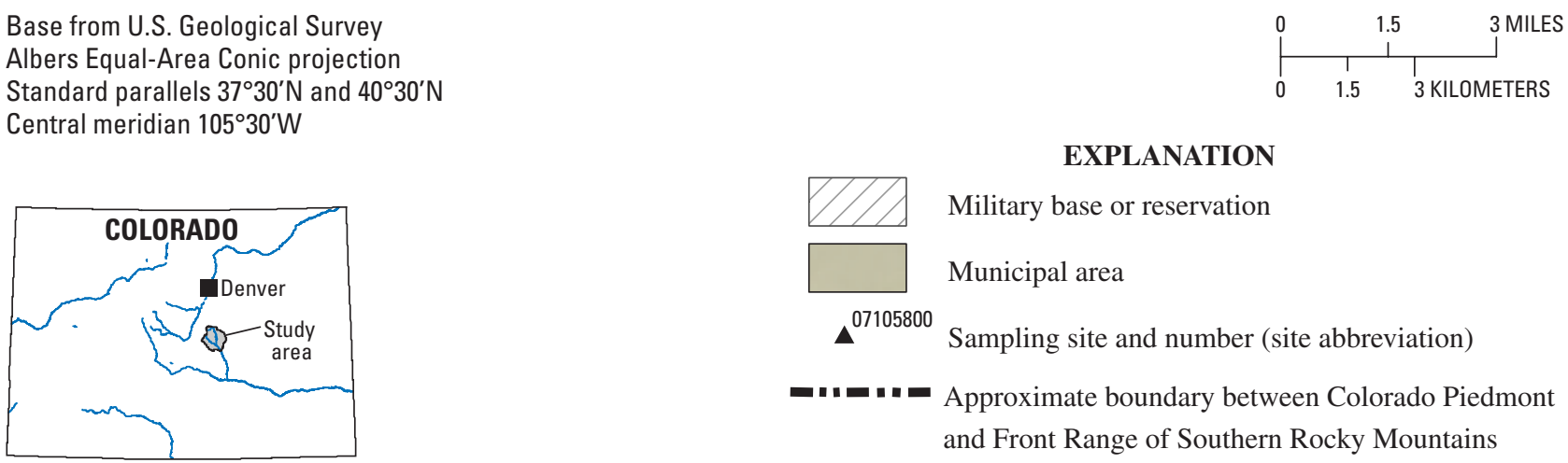

\section{EXPLANATION}

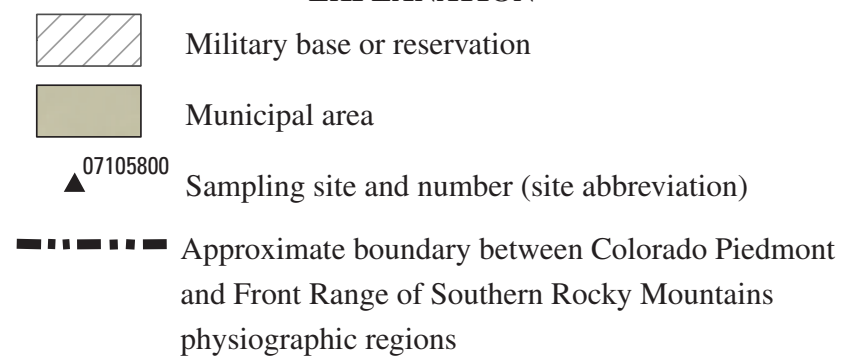

Figure 1. Location of study area and sampling sites for the Fountain and Monument Creek watersheds. 


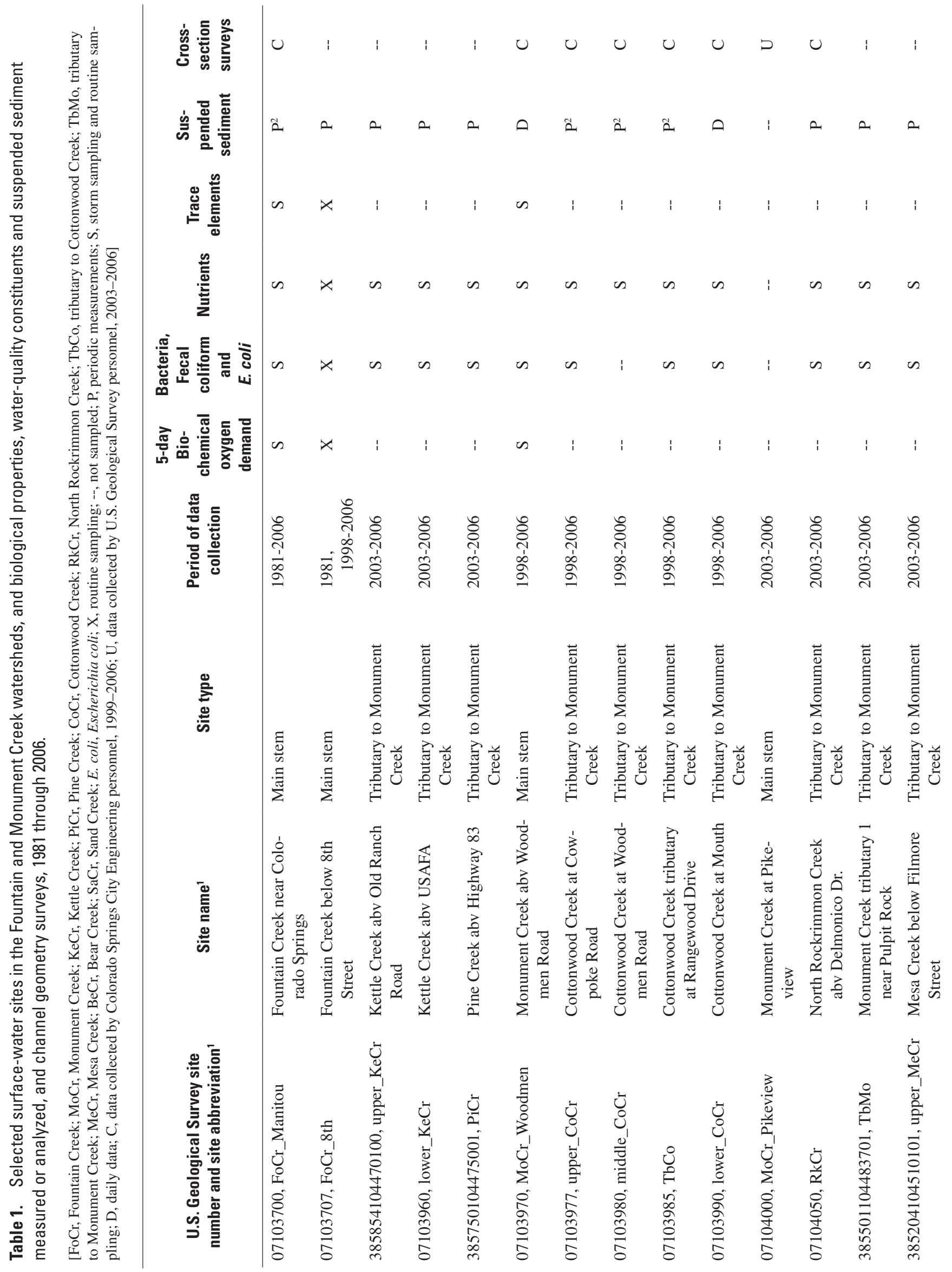




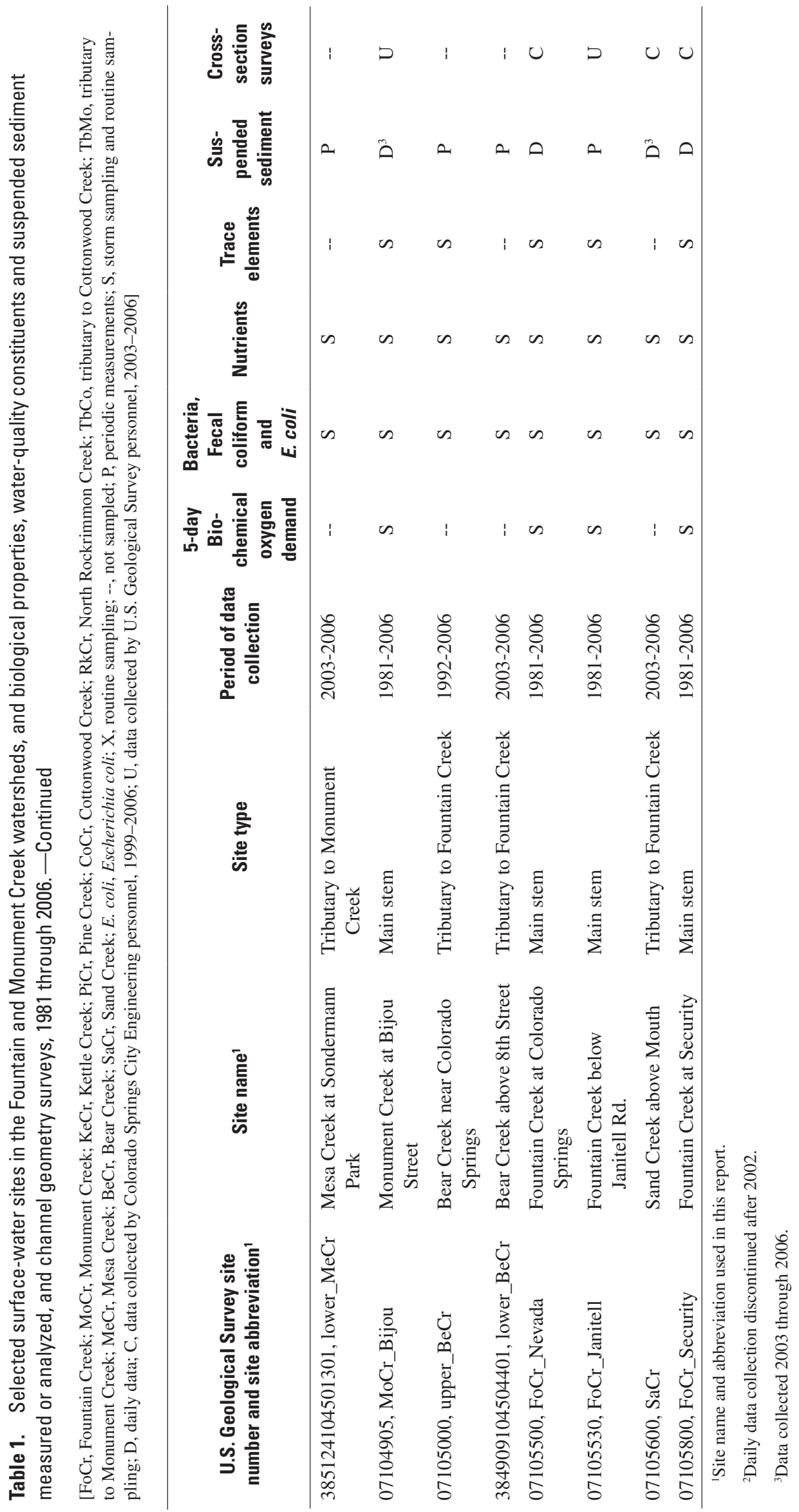


Measurements of specific conductance, $\mathrm{pH}$, dissolved oxygen, biochemical oxygen demand $\left(\mathrm{BOD}_{5}\right)$, fecal coliform and Escherichia coli (E. coli), nitrogen, phosphorus, and selected trace elements were used to describe the water quality in the Fountain and Monument Creek watersheds in the vicinity of Colorado Springs, Colorado.

Suspended-sediment samples were collected in conjunction with routine and stormwater-quality samples to evaluate variations in suspended-sediment concentrations, discharge, and yield. Samples were collected from April 1 through September 30 during the period 1998 through 2005. In addition to periodic routine and storm suspendedsediment samples, samples were collected daily by automatic samplers at Monument Creek above Woodmen (site 07103970, MoCr_Woodmen), Cottonwood Creek at the mouth (site 07103990, lower_CoCr), Monument Creek at Bijou Street (site 07104905, MoCr_Bijou), Fountain Creek at Colorado Springs (site 07105500, FoCr_Nevada), Sand Creek above mouth (site 07105600, SaCr), and Fountain Creek at Security (site 07105800 , FoCr_Security) to evaluate daily variations in suspended-sediment concentrations, discharge, and yield. Automatic samplers were operated annually from April 1 through September 30. Periodic and daily samples were used to evaluate annual and spatial variations in suspended-sediment concentrations, discharge, and yield that occurred during base flow, normal flow, and stormflow to determine relative source areas of sediment in the watershed.

Changes in channel morphology were assessed by surveying cross sections at selected locations on Fountain and Monument Creeks, Cottonwood Creek, North Rockrimmon Creek, and Sand Creek. Selected reaches at 10 sites (table 1) were surveyed annually by Colorado Springs City Engineering employees. Selected cross sections at three sites (table 1) were surveyed multiple times during the year by U.S. Geological Survey employees.

\section{Description of Study Area}

The study area has a drainage area of about $500 \mathrm{mi}^{2}$ and encompasses most of the urbanized area within the Fountain and Monument Creek watersheds. Elevations in the study area range from 14,109 $\mathrm{ft}$ at the summit of Pikes Peak to $5,460 \mathrm{ft}$ at the southern end of the study area. There are two major physiographic regions in the study area - the Front Range of the Southern Rocky Mountains and the Colorado Piedmont (Hansen and Crosby, 1982). The Front Range, which comprises about the western one-third of the study area, is underlain by granite. Soils in this area are well drained and lie on steep slopes (Larsen, 1981; von Guerard, 1989a). The Colorado Piedmont, which comprises the remaining eastern two-thirds of the area, abuts the base of the Rampart Range and is underlain by sandstone, shale, and alluvial and windlain deposits. Soils in this area generally are sandy and well drained with gentler slopes (Larsen, 1981; von Guerard, 1989a). The soils and geology on the Colorado Piedmont are readily erodible, especially relative to the granitic rocks on the west side of the study area. More details of the soils and geology of the study area are contained in Larsen (1981) and von Guerard (1989a).

The population of El Paso County, which includes Colorado Springs, has increased from about 70,000 people in 1950 to about 310,000 in 1980, to about 510,000 in 2000 (U.S. Census Bureau, 2007). The 2006 population is estimated at about 562,000. The rate of growth, about 8,000 people per year, was fairly constant between 1950 and 1990. Between 1990 and 2000, the rate of growth increased to about 11,000 people per year (Stogner, 2000). In recent years the rate of growth has slowed to about 8,600 people per year (The Gazette, 2006). This report uses data collected at 22 sites throughout the Fountain and Monument Creek watersheds and frequently refers to site identification numbers to provide a spatial reference. An abbreviated naming convention for each site was developed to assist the reader and is linked to the creek where the site is located (table 1). For example, site 07104905 (MoCr_Bijou) refers to site 07104905, located on Monument Creek at Bijou Street.

\section{Land Use}

Land uses within the study area include agriculture, commercial, industrial, residential, streets and easements, airports and military reservations, and undeveloped areas. Substantial changes in land use have occurred from increased population. Table 2 shows estimated impervious area and the total area for various land-use categories for 1997 , 2001, and 2005 in the Fountain and Monument Creek watersheds. Estimates of the total impervious area were based on coefficients developed from Pikes Peak Area Council of Governments (PPACG) (2005). Estimates of the percentage of impervious and pervious material associated with each land use were applied using coefficients adopted from PPACG (2005) (table 3). The percent imperviousness (4 percent of agricultural, 20-98 percent of commercial, 35-85 percent of industrial, 12-65 percent of residential, 10-98 percent of streets and easements, 13 percent of airports and military reservations, and 2-4 percent of undeveloped land-use categories) varied based on parcel size and landuse subcategory definitions. Land-use data for 1997 through 2005 were provided by the City of Colorado Springs. A Geographic Information System (Environmental Systems Research Institute, Inc., 2005) was used to compute area and imperviousness of land-use categories and subcategories. The amount of estimated impervious area within El Paso County (fig. 1) upstream from site 07105800 (FoCr_Security) increased from $68.8 \mathrm{mi}^{2}$ in 1997 and $75.7 \mathrm{mi}^{2}$ in 2001 to about $80 \mathrm{mi}^{2}$ in 2005 (table 2). 


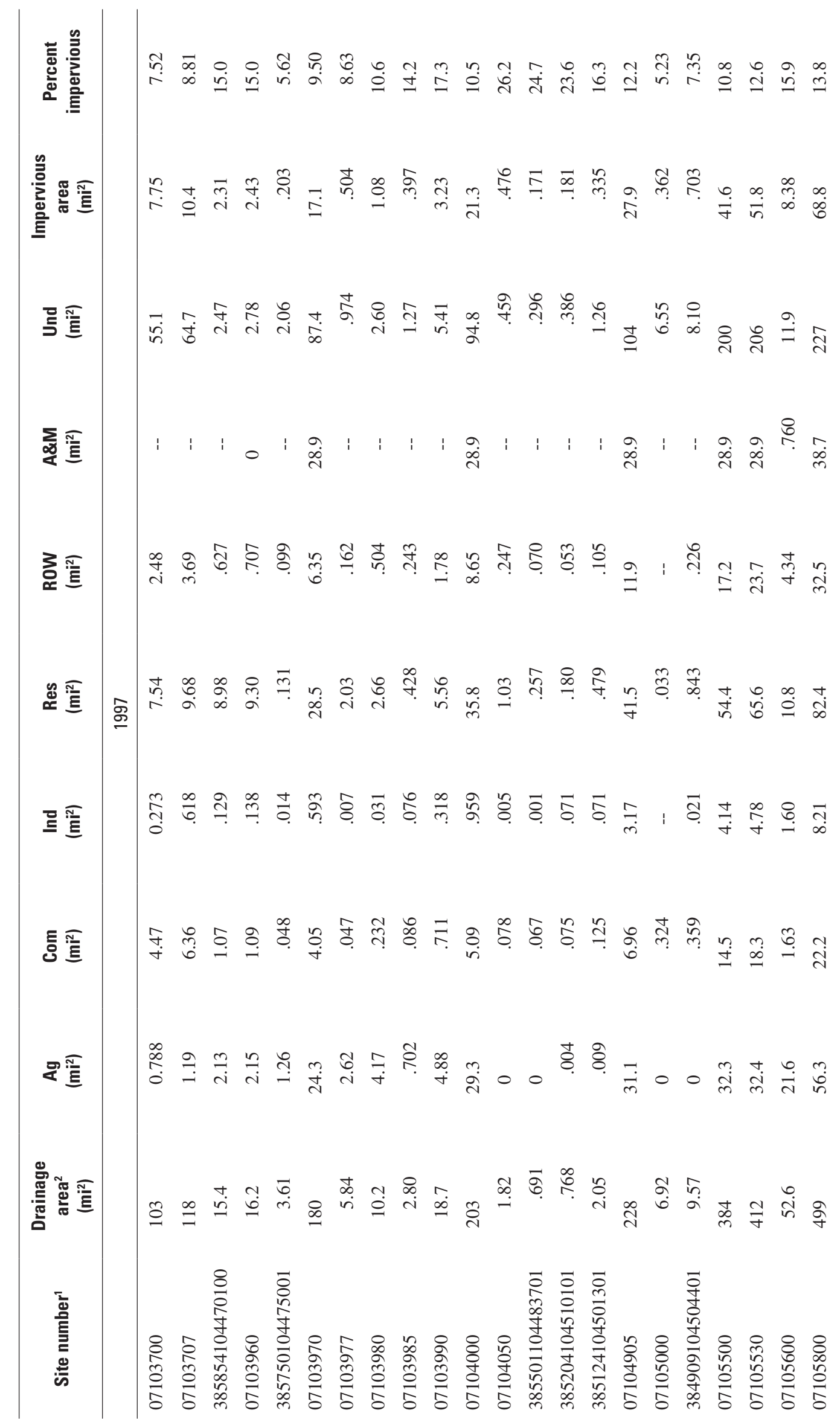




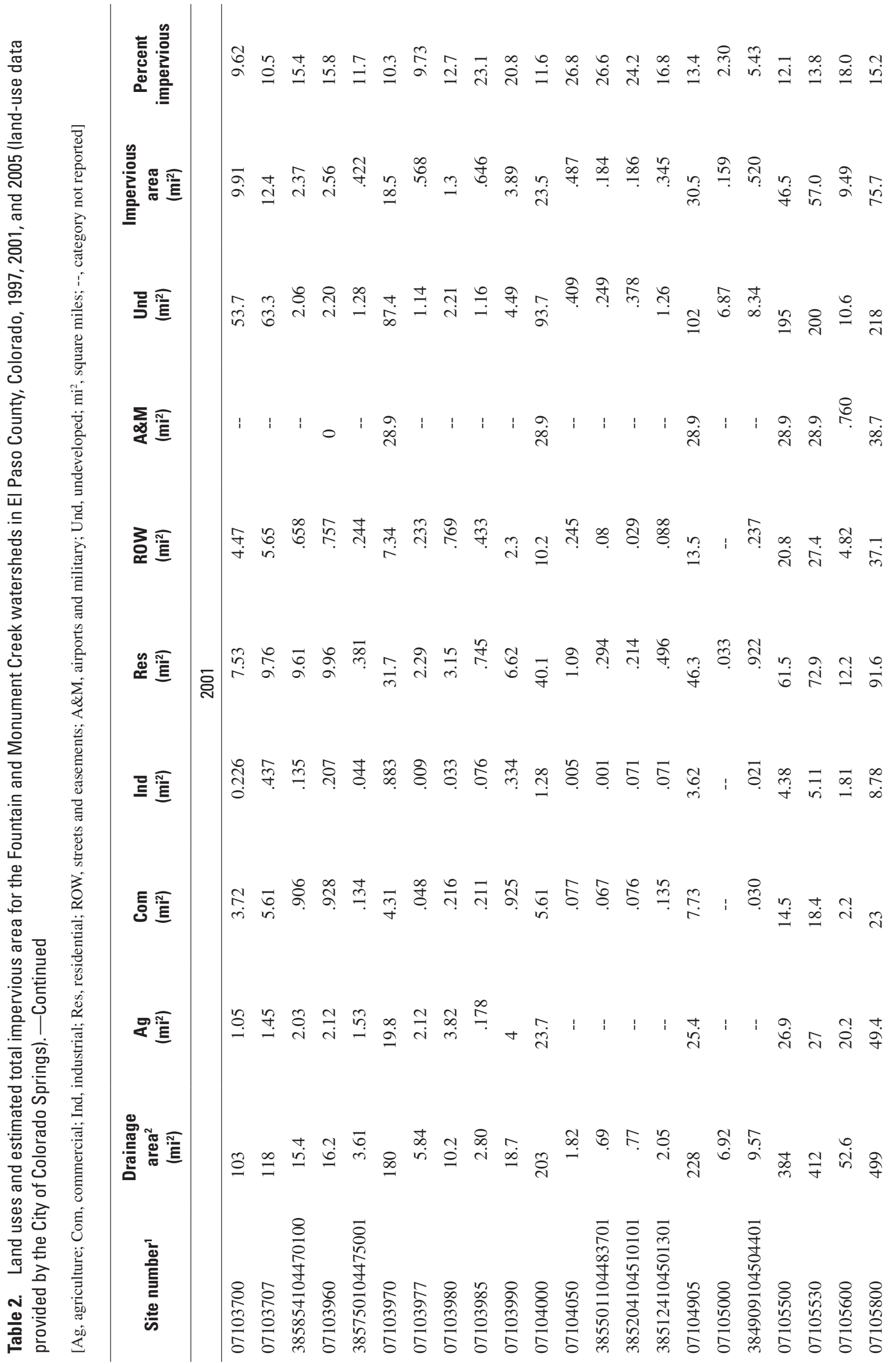




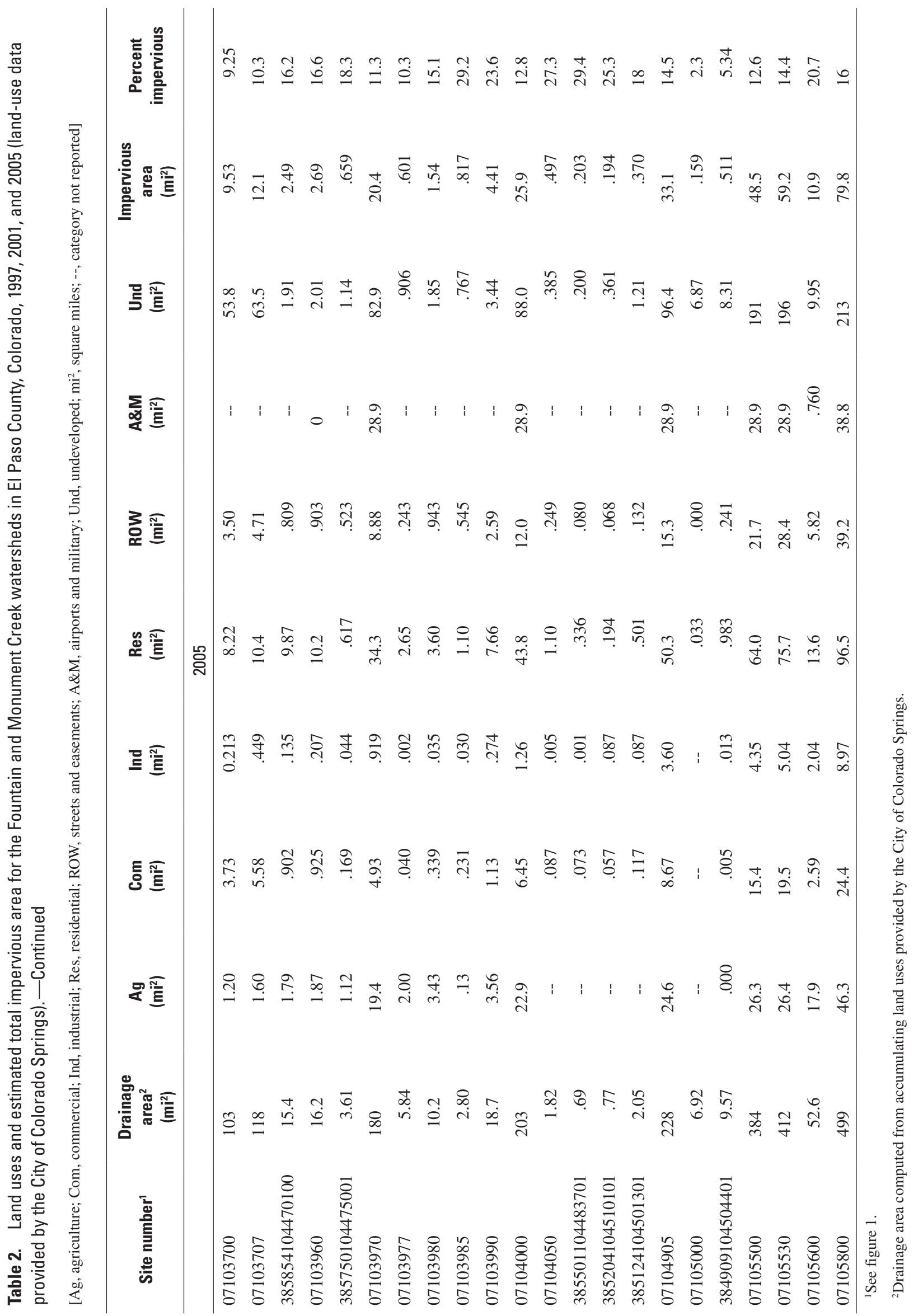


Table 3. Imperviousness coefficients for land-use categories and subcategories in the Fountain and Monument Creek watersheds.

[du, development unit, R\&D, research and development; res, residential; ROW, streets and easements]

\begin{tabular}{|c|c|c|}
\hline Land-use category & Land-use subcategory & $\begin{array}{c}\text { Imperviousness } \\
\text { coefficient }\end{array}$ \\
\hline agriculture & Agriculture & 4 \\
\hline agriculture & Special purpose & 4 \\
\hline airports and military & Airport/military installation & 13 \\
\hline commercial & Office low & 20 \\
\hline commercial & Office medium & 35 \\
\hline commercial & Primary/Secondary school & 35 \\
\hline commercial & University/conference center & 35 \\
\hline commercial & Parking/vacant & 60 \\
\hline commercial & Commercial services & 70 \\
\hline commercial & Common commercial & 70 \\
\hline commercial & Community commercial & 70 \\
\hline commercial & Exempt \& undefinable & 70 \\
\hline commercial & Major public assembly & 70 \\
\hline commercial & Minor public assembly & 70 \\
\hline commercial & Neighborhood commercial & 70 \\
\hline commercial & Undefined institutional use & 70 \\
\hline commercial & Unspecified commercial & 70 \\
\hline commercial & Unspecified office & 70 \\
\hline commercial & Detention center & 85 \\
\hline commercial & Fire station & 85 \\
\hline commercial & Highway-oriented commercial & 85 \\
\hline commercial & Hospital & 85 \\
\hline commercial & Library & 85 \\
\hline commercial & Museum & 85 \\
\hline commercial & Office high & 85 \\
\hline commercial & Police & 85 \\
\hline commercial & Public safety & 85 \\
\hline commercial & Regional commercial & 85 \\
\hline commercial & Parking lot/black top & 98 \\
\hline commercial & Parking structure & 98 \\
\hline industrial & Office-Industrial Park/R\&D & 35 \\
\hline industrial & General industrial & 70 \\
\hline industrial & Industrial & 70 \\
\hline industrial & Warehouse/wholesale & 70 \\
\hline
\end{tabular}


Table 3. Imperviousness coefficients for land-use categories and subcategories in the Fountain and Monument Creek watersheds. - Continued

[du, development unit, R\&D, research and development; res, residential; ROW, streets and easements]

\begin{tabular}{|c|c|c|}
\hline Land-use category & Land-use subcategory & $\begin{array}{l}\text { Imperviousness } \\
\text { coefficient }\end{array}$ \\
\hline industrial & Mining & 85 \\
\hline residential & $0-1.99$ res. du/acre & 12 \\
\hline residential & 2.0-3.49 res du/acre & 21 \\
\hline residential & $3.5-7.99$ res du/acre & 28 \\
\hline residential & Unspecified density (res) & 33 \\
\hline residential & Unspecified density (res) & 33 \\
\hline residential & Unspecified density (res) & 33 \\
\hline residential & $12.0-24.99 \mathrm{res} \mathrm{du} / \mathrm{acre}$ & 39 \\
\hline residential & $25+$ res du/acre & 39 \\
\hline residential & $8.0-11.99 \mathrm{res} \mathrm{du} / \mathrm{acre}$ & 39 \\
\hline residential & Common residential area & 65 \\
\hline residential & Condo/Townhome & 65 \\
\hline streets and easements & Undefined public use & 10 \\
\hline streets and easements & Other public street ROW & 60 \\
\hline streets and easements & Private street ROW & 60 \\
\hline streets and easements & Undefined easement & 60 \\
\hline streets and easements & Undefined street ROW & 60 \\
\hline streets and easements & Unspecified ROW/Easement & 60 \\
\hline streets and easements & Utility easement/ROW/Facil & 60 \\
\hline streets and easements & Collector street ROW & 85 \\
\hline streets and easements & Undefined street ROW & 85 \\
\hline streets and easements & Arterial street & 98 \\
\hline streets and easements & Drainage easement, and so forth & 98 \\
\hline undeveloped & Cemetery & 2 \\
\hline undeveloped & Community park & 2 \\
\hline undeveloped & Golf course & 2 \\
\hline undeveloped & Neighborhood park & 2 \\
\hline undeveloped & Open space & 2 \\
\hline undeveloped & Regional park & 2 \\
\hline undeveloped & Trail & 2 \\
\hline undeveloped & Undefined - open space & 2 \\
\hline undeveloped & Undefined park & 2 \\
\hline undeveloped & Vacant land & 2 \\
\hline undeveloped & Sports complex & 4 \\
\hline
\end{tabular}




\section{Acknowledgments}

The authors appreciate the efforts of those who assisted in the collection of these data. Thanks to Lisa Ross, Colorado Springs City Engineering, for help with planning and support for the monitoring program. Thanks also to Joel Mackey and GIS staff at Colorado Springs City Engineering for their cooperation and support and for providing land-use and crosssection survey data and to Richard Muzzy, Pikes Peak Area Council of Governments, for assistance with developing landuse imperviousness coefficients. Finally, thanks to Lauri Krall, Sheryl Ferguson, Erin Evans, Wade Walker, Nick Young, R.J. Ortiz, John Ragulsky, Krystal Tezak, and Jason Stewart, U.S. Geological Survey, for their dedication and tireless efforts in the collection and processing of stormflow samples under harsh field conditions.

\section{Methods of Investigation}

\section{Flow Regime}

Water quality commonly varies with different streamflow regimes. As stated previously, streamflow in the Fountain and Monument Creek watersheds varies seasonally; therefore, for purposes of this report, water-quality data were separated into three flow regimes: base flow, normal flow, and stormflow. Water-quality samples collected between November 1 and April 30 that were unaffected by stormflow were identified as base-flow samples. Water-quality samples collected during the remainder of the year that were unaffected by stormflow were identified as normal-flow samples. Samples that were collected during storm runoff were identified as stormflow samples. Water-quality data associated with base flow, normal flow, and stormflow were compared to characterize variations in water quality that exist among the different flow regimes. Water-quality data determined to have been associated with stormflow were identified by visual inspection of the hydrograph, available precipitation data, and water-quality concentration and sediment data and by using a base-flow-separation program (Wahl and Wahl, 1995).

Discharges generally were obtained from streamflow measurements at USGS streamflow-gaging stations. Streamflow at gaging stations is estimated after developing the relation of stage to streamflow for a particular location (Buchanan and Somers, 1968; Carter and Davidian, 1968; Kennedy, 1983, 1984). At a typical USGS streamflow-gaging station, stream stage, or the level of water in the stream, is recorded at periodic intervals. Based on a relation between stage and streamflow, recorded stream stage is used to estimate streamflow. Streamflow data used in this report are available from the USGS National Water Information System (NWIS) (2007).

\section{Water-Quality Data}

Water-quality data were collected and processed using standard USGS techniques and procedures (U.S. Geological Survey, 1977; Sylvester and others, 1990; Horowitz and others, 1994; Wilde and others, 1998). Since 1994, sampling equipment has been cleaned using the part-per-billion protocols. Field measurements that are discussed in this report are specific conductance, $\mathrm{pH}$, and dissolved oxygen. Water samples collected between 1981 and 1997 were analyzed by the USGS National Water-Quality Laboratory (NWQL), Lakewood, Colorado. Water samples collected between 1998 and 2002 were analyzed by the Colorado Springs Utilities Environmental Quality Laboratory with quality-control samples analyzed by the NWQL. Water-quality data from the Colorado Springs Utilities Environmental Quality Laboratory that were used in this report were comparable to the waterquality data analyzed by the NWQL. Beginning in 2003 all water-quality data were collected and analyzed at the NWQL. Samples for analysis of 5-day biochemical oxygen demand $\left(\mathrm{BOD}_{5}\right)$ were collected at seven main-stem sites in the study area. Samples collected for biochemical oxygen demand were processed in the USGS Colorado Water Science Center Pueblo office laboratory (USGS Pueblo laboratory) until 1997, Colorado Springs Utilities Environmental Quality Laboratory from 1998 until 2002, and then the USGS Pueblo laboratory beginning in 2003. Water-quality data used in this report are available from the USGS National Water Information System (NWIS) (2007).

Quality-control samples were routinely collected and analyzed to identify, quantify, and document bias and variability in the collection and processing of data. Sample processing was done primarily in a mobile USGS laboratory located at the sampling site; therefore, field blanks were collected to measure the environmental conditions in the mobile laboratory. Quality-control samples were submitted to the appropriate laboratory for analysis. Blank samples analyzed for inorganic constituents were prepared with inorganic grade water from the USGS Ocala (Florida) Field Services Unit or NWQL where the water is quality assured for suitability in the testing of equipment and sampling. In addition to blank samples, several replicate samples were collected to assess the variability among samples resulting from collection, processing, and laboratory procedures conducted at different sampling times (Wilde and others, 1998).

Results from field blanks for constituents analyzed in this report indicated that field blanks were free of contamination. There were isolated instances of detections of dissolved ammonia that were near the laboratory analytical detection limit, but these detections were not considered to affect sample integrity. There also were isolated instances of low-level detections of dissolved boron and dissolved selenium. Dissolved boron was detected once during 2001 at $0.01 \mathrm{mg} / \mathrm{L}$, 
and dissolved selenium was detected once in 2000 at a concentration of $2.0 \mu \mathrm{g} / \mathrm{L}$.

The mean relative percentage difference in replicate samples ranged from about 7 percent for nutrient concentrations to about 11 percent for trace-element concentrations. Relative percentage difference was calculated as the absolute difference between the replicate and original sample concentrations divided by the average of the two values, multiplied by 100. When constituent concentrations are low, small absolute differences between the original and replicate sample result in larger relative percentage differences. Overall, the magnitude of the difference was within 10 percent for most constituents.

\section{Suspended-Sediment Data}

Suspended-sediment samples generally were collected daily from April through September each year from 1998 through 2005 at six sites (table 1). Suspended-sediment samples were manually collected as described by Edwards and Glysson (1988) and analyzed at the USGS Iowa Water Science Center Sediment Laboratory, Iowa City, Iowa. Discrete point samples were collected using automatic samplers installed at selected streamflow gages that were programmed to collect samples daily and during rises in stream stage. Suspendedsediment concentrations obtained from samples collected at a single point within the cross section were adjusted on the basis of relations developed from depth-integrated samples collected periodically using the equal-width-increment method (Koltun and others, 1994). For data collected between 1998 and 2000, daily suspended-sediment concentration and streamflow were subdivided using the SEDCALC program with the linear interpolation, uneven time interval option to compute the daily mean suspended-sediment concentration and discharge (Koltun and others, 1994). For data collected since 2001, the same procedure was done using the GCLAS program (Koltun and others, 2006). Suspended-sediment data for samples that were collected manually are available from the USGS National Water Information System (NWIS) (2007); suspended-sediment data for discrete point samples collected using automatic samplers are available upon request from the USGS Colorado Water Science Center Pueblo office.

\section{Boxplots}

Water-quality and suspended-sediment data presented in this report are summarized using boxplots. Boxplots graphically display the constituent variability and provide an easy method for comparing spatial, temporal, and flow-related data. Boxplots are useful because the variability between data sets, unusual values, and selected summary statistics are easily observed. Boxplots contain the following information. The horizontal line within the box represents the median value (50 percent of the data are larger than this value and 50 percent of the data are less than this value). The lower horizontal line of the box is the 25 th percentile or lower quartile ( 25 percent of the data are less than this value). The upper horizontal line of the box is the 75 th percentile or upper quartile ( 75 percent of the data are less than this value). The interquartile range (IQR) contains the values between the 25 th and 75 th percentiles and is the difference between the 25th and 75 th percentiles. The bottom of the vertical line on the boxplot is the smallest value within 1.5 times the IQR of the box. The top of the vertical line on the boxplot is the largest value within 1.5 times the IQR of the box. Outside values are larger than 1.5 times the IQR from the box and outlier values are larger than 3 times the IQR from the box. An example of a boxplot is shown here:

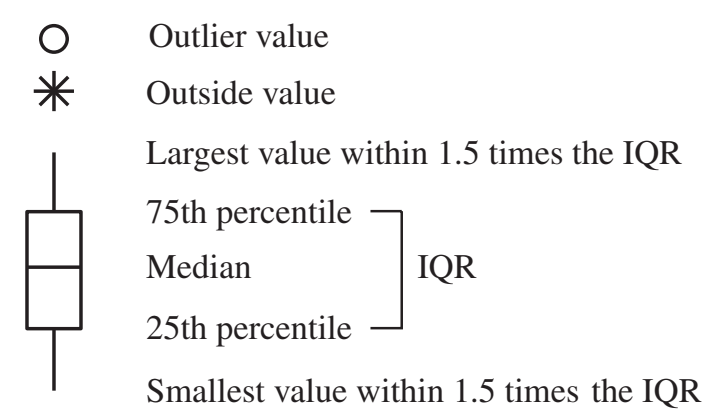

\section{Statistical Analyses}

Parametric and nonparametric statistical analyses were applied to the data to compare relations between selected water-quality constituents and to evaluate spatial and temporal differences in water quality and suspended sediment. The Tukey analysis used in this report is a parametric multiple comparison test based on rank-transformed data (to approximate a normal distribution) and was used to identify statistical differences in selected water-quality constituents among various sites and flow regimes. Results from the Tukey analysis provide the statistical significance of those trends (Helsel and Hirsch, 1992).

Nonparametric analyses used in this report included the Spearman's rho correlation test, the Kruskal-Wallis test of independent groups, the Kendall's tau test, and the MannWhitney test (Helsel and Hirsch, 1992). Nonparametric tests use ranks of data as opposed to real data values and are used if data are not normally distributed and if parametric statistical techniques are skewed by large outliers. Spearman's rho test was used to determine correlation between land-use categories and water-quality constituents. The Kruskal-Wallis test was used to determine whether there was a statistical difference between the medians of two independent groups. The test was used in this report to determine if the data collected between two periods, 1981 through 1997 and 1998 through 2006, were significantly different. The Kendall's tau test was used to determine whether a trend occurred with precipitation over time. The Mann-Whitney test was used to determine whether there were spatial and temporal differences for suspended- 
sediment concentrations, discharge, and suspended-sediment yields. The probability of error ( $\mathrm{p}$-value) was used in this report to determine the significance of statistical tests for all statistical methods. A p-value of less than 0.05 (95-percent confidence that the statistical test is valid, or that the compared data sets are different) was used in this report to indicate if a statistical test was significant.

\section{Precipitation and Streamflow}

Annual precipitation in the Fountain and Monument Creek watersheds generally decreases with distance from the headwaters of the watershed and as elevation decreases. The mean annual precipitation varies considerably from year to year. At the Colorado Springs Weather Service Office (WSO) at Peterson Air Force Base (fig. 1), annual precipitation for 1949 through 2006 ranged from 7.8 to 27.6 inches (fig. 2). Annual precipitation increased significantly between 1949 and $2001(\mathrm{p}<0.05)$. The mean annual precipitation increased from 14.9 inches from 1949 through 1980 to 18.5 inches from 1981 through 2001 . The mean annual precipitation decreased to 13.5 inches for the period 2001 through 2006, primarily due to the 2002 drought conditions. However, even when 2002 was removed from the calculation of the mean, the Colorado Springs area received on average 14.5 inches of precipitation during the most recent period, which is similar to the recorded mean precipitation from 1949 through 1980 (14.9 inches). Between 1998 and 2006, when most of the data used in this report were collected, the annual precipitation ranged from 7.8 inches in 2002 to 27.6 inches in 1999, which represents the minimum and the maximum annual precipitation for the 52-year period of record. Convective thunderstorms contribute most of the rainfall during May through September. Based on 1998 through 2006 precipitation data, about 79 percent of the daily precipitation that occurs is less than 0.25 inch, about 13 percent is between 0.26 and 0.5 inch, about 3 percent is between 0.51 and 0.75 inch, about 2 percent is between 0.76 and 1 inch, and about 3 percent is larger than $1 \mathrm{inch}$. These data indicate that daily precipitation larger than 0.25 inch occurs an average of 77 days each year; daily precipitation larger than 0.5 inch occurs an average of 28 days each year; and daily precipitation larger than 1 inch occurs an average of 10 days each year. The precipitation values breakdown from 1998 through 2006 is similar to the values for the period 1981 through 1997, with the exception that precipitation larger than 0.5 inch decreased 20 percent during the 1998 through 2006 period. Between 1998 and 2006, the number of runoff events per year generally ranged from 70 to 90 , with an average of 84.

The three flow regimes, base flow, normal flow, and stormflow, were applied to streamflow in the Fountain and Monument Creek watersheds. During base flow, streamflow is fairly uniform and is sustained by ground-water discharge, wastewater effluent, and other regulated discharges. Normal flow generally begins in May with the onset of snowmelt and extends into October. Streamflow during normal flow is highly variable. Changes in streamflow during the summer are primarily caused by convective thunderstorms. Stogner (2000) evaluated trends in streamflow regimes from 1977 through 1999. Significant increases in high-streamflow and lowstreamflow regimes were detected at most sites on Fountain and Monument Creeks in the study area during this time period.

As part of this study, the number of stormflow events from May through October for each year were estimated from 1981 through 2006 by using a program to separate the base-flow component from the daily mean streamflow (Wahl and Wahl, 1995). The program implements a deterministic procedure to estimate the base-flow component of the daily hydrograph by combining a local minimums approach with a recession slope test. Based on inspection of streamflow hydrographs, a decision was made that daily mean streamflow larger than 2 times the computed daily base flow was a conservative indicator of stormflow for all main-stem sites. For the tributary sites, a decision was made that daily mean streamflow larger than 3 times the computed daily base flow was a conservative indicator of stormflow.

Instantaneous streamflow measurements made during water-quality sampling varied by site and flow regime. In addition, certain sites and flow regimes were significantly different between 1981 through 1997 and 1998 through 2006 (fig. 3). Streamflow for Fountain and Monument Creeks at main-stem sites during 1998 through 2006 generally increased from upstream to downstream for all flow regimes. On Fountain Creek, upstream from the confluence with Monument Creek, streamflow is diverted upstream from site 07103707 (FoCr_8th), reducing median normal flow from $15.0 \mathrm{ft}^{3} / \mathrm{s}$ to $3.2 \mathrm{ft}^{3} / \mathrm{s}$ (fig. $3 A$ ). On Monument Creek, upstream from the confluence of Fountain and Monument Creeks, median normal flow increased between the upstream site, 07103970 (MoCr_Woodmen), and the downstream site, 07104905 (MoCr_Bijou), by more than 80 percent from 11 to $20 \mathrm{ft}^{3} / \mathrm{s}$. Median stormflow discharge that was sampled for water-quality constituents between those same two sites increased by almost 50 percent. Much of this is attributed to the many tributaries that drain to Monument Creek, with median normal and stormflow discharge at the measured tributary sites ranging from less than 1.0 to $5.3 \mathrm{ft}^{3} / \mathrm{s}$ during normal flow to less than 1.0 to $22 \mathrm{ft}^{3} / \mathrm{s}$ during stormflow. Fountain Creek discharge increased downstream from the confluence because of the combined discharge from Fountain Creek and Monument Creek. Discharge from two wastewater treatment-plants located downstream from site 07105500 (FoCr_Nevada) also contributed to the overall increase in discharge to Fountain Creek. During 1998 through 2006, median normal flow increased by 200 percent between sites 07105500 (FoCr_Nevada) and 07105530 (FoCr_Janitell) because of discharge from the Las Vegas Street Wastewater Treatment Plant (fig. 3A; fig. 1). Sand Creek enters Fountain Creek downstream from site 07105530 (FoCr_Janitell), and 

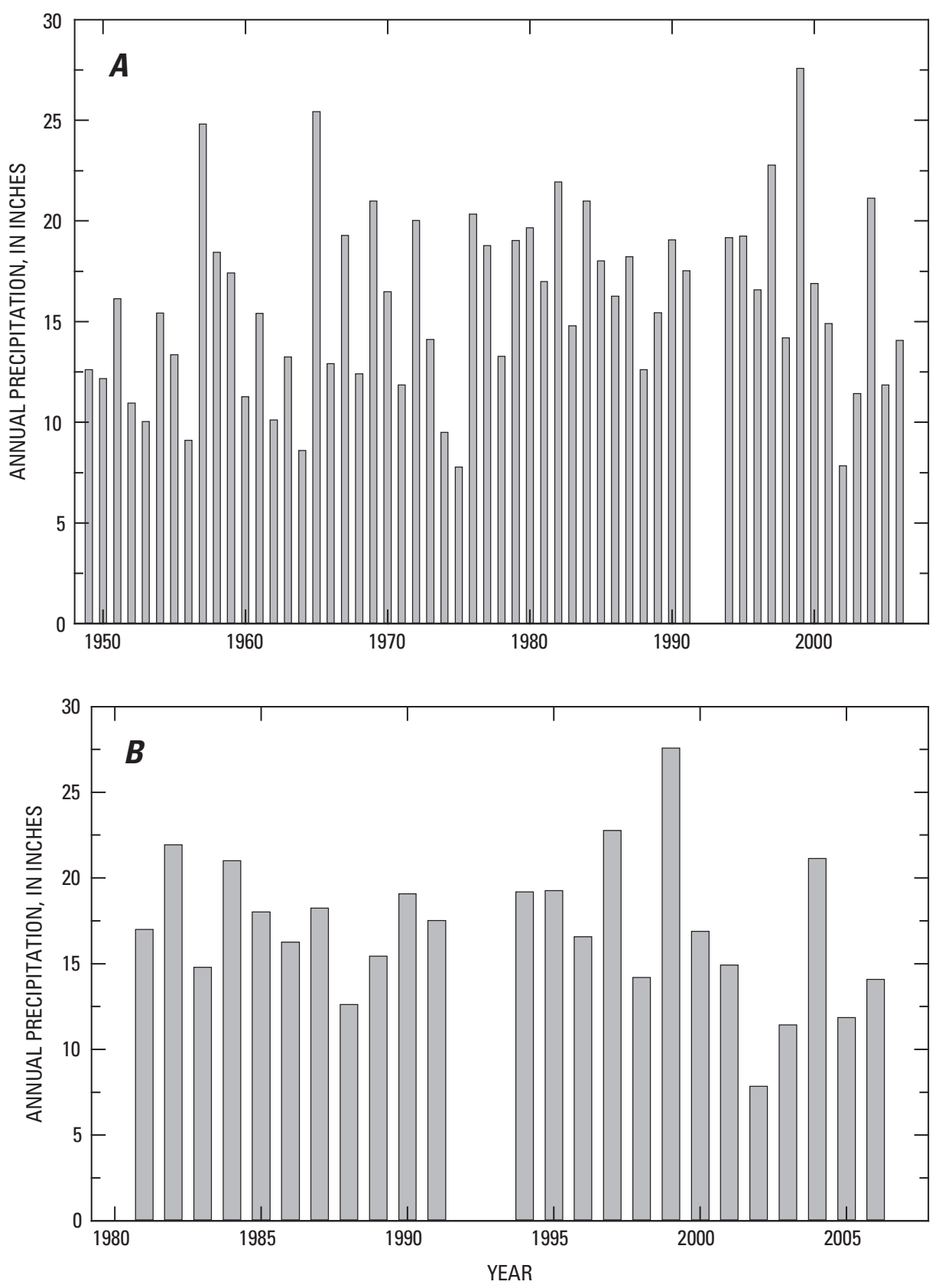

Figure 2. Annual precipitation at the Colorado Springs Weather Service Office, $(A) 1949$ through 2006, and (B) 1981 through 2006. 

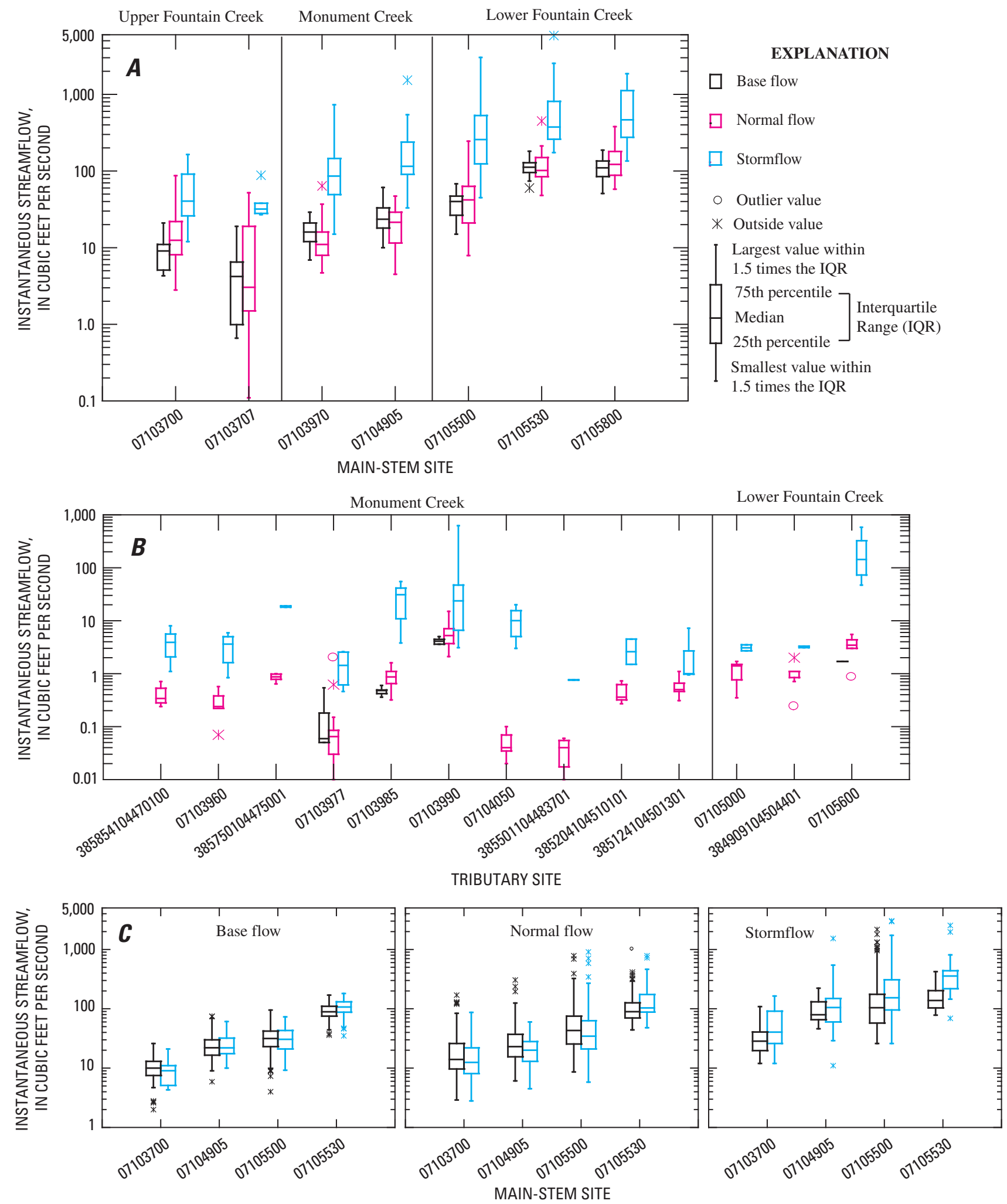

EXPLANATION

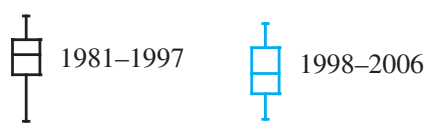

Figure 3. Variations in sampled streamflow at $(A)$ main-stem sites, and $(B)$ tributary sites for base flow, normal flow, and stormflow in Fountain and Monument Creek watersheds, 1998 through 2006, and $(C)$ comparison of sampled streamflow at selected main-stem sites between 1981 through 1997 and 1998 through 2006. 
although median normal-flow discharges to Fountain Creek were small $\left(3.0 \mathrm{ft}^{3} / \mathrm{s}\right)$, median stormflow discharges were about $250 \mathrm{ft}^{3} / \mathrm{s}$ and ranged from 5.5 to more than $1,000 \mathrm{ft}^{3} / \mathrm{s}$.

A comparison of flow conditions between 1981 through 1997 and 1998 through 2006 at selected mainstem sites in upper Fountain Creek and Monument Creek, based on discharge measurements associated with waterquality sampling, indicated that base flow and normal flow discharge generally had not changed (fig. 3C). In Monument Creek, median stormflow discharge at site 07104905 (MoCr_Bijou) increased from about $80 \mathrm{ft}^{3} / \mathrm{s}$ to $105 \mathrm{ft}^{3} / \mathrm{s}$; the range of stormflow discharges was larger during 1998 through 2006, ranging from 11 to $1,530 \mathrm{ft}^{3} / \mathrm{s}$ compared to 46 to $222 \mathrm{ft}^{3} / \mathrm{s}$ during 1981 through 1997 . The largest change in flow measurements between the two periods occurred at site 07105530 (FoCr_Janitell), where the increase in discharge is related to the Las Vegas Street Wastewater Treatment Plant. Discharges at site 07105530 (FoCr_Janitell) increased an average of about 20 percent during nonstormflow conditions and more than 160 percent during stormflow conditions between the two periods 1981 through 1997 and 1998 through 2006 (fig. 3C).

\section{Water Quality}

The following sections of this report describe waterquality conditions in the Fountain and Monument Creek watersheds. Specifically, this section compares water-quality concentrations to selected land-use categories, compares water-quality concentrations to in-stream water-quality standards, compares water-quality concentrations for different flow regimes, compares water-quality concentrations between 1981 through 1997 and 1998 through 2006, and finally, characterizes water-quality loads for selected constituents.

\section{Relation of Water Quality to Land Use}

Differing land uses and changes in land use can influence stream hydrology and water quality. Several land-use categories in the Fountain and Monument Creek watersheds, including agriculture, commercial, industrial, residential, streets and easements, airports and military reservations, and undeveloped lands, were investigated to determine if statistically significant relations could be identified between various water-quality constituents, physical properties, and land use in the Fountain and Monument Creek watersheds within the study area. Relations were evaluated using a Spearman's rho correlation analysis (table 4). Streamflow was strongly correlated $(r>0.8)$ with impervious area and for most land-use categories evaluated. Of the physical properties and water-quality constituents evaluated, only specific conductance and total phosphorus generally were indicated to have statistically significant correlation coefficients larger than 0.6. Other water-quality constituents (table 4) such as dissolved nitrite plus nitrate and dissolved ammonia were significantly correlated, but these constituents had correlation coefficients smaller than 0.6, indicating that less than 40 percent of the variation in water quality could be explained by variations in land use.

\section{Comparison of Stormflow Water Quality to Colorado In-Stream Water-Quality Standards}

In-stream water-quality standards have been established for stream segments in the Fountain and Monument Creek watersheds. Standards are based on stream classifications and the designated use of the stream segment as determined by the Colorado Department of Public Health and Environment (CDPHE) Water Quality Control Commission with public participation (Colorado Department of Public Health and Environment, 2006).

Numeric standards have been set for both fecal bacteria and Escherichia coli (E. coli) bacteria that are based on five-sample geometric means over a 30-day period. The water-quality standards for fecal coliform and $E$. coli are $200 \mathrm{col} / 100 \mathrm{~mL}$ and $126 \mathrm{col} / 100 \mathrm{~mL}$, respectively. This study did not collect sufficient bacteria samples for regulatory purposes; therefore, numeric standards based on geometric means do not apply in this report. The standard for E. coli bacteria that was referenced in this report was based on the one-time primary contact standard of $235 \mathrm{col} / 100 \mathrm{~mL}$ and is statistically similar to the $126-\mathrm{col} / 100 \mathrm{~mL}$ standard based on the five-sample geometric means over a 30-day period (U.S. Environmental Protection Agency, 1986). During periods of normal flow and stormflow, E. coli exceeded the primary contact standard and will be discussed further in the report.

Standards for many constituents are fixed values; standards for other constituents, specifically for some trace elements, are calculated values that use mean hardness in determining the standard for each site. The mean hardness used in this report was calculated at each main-stem site by using the lower 95-percentile confidence interval for base-flow water-quality samples collected between November and March (Colorado Department of Public Health and Environment, 2006). Standards have been established for 13 trace elements, depending on the stream reach, and most of the standards are applied to dissolved constituents (Colorado Department of Public Health and Environment, 2006). In this report, waterquality concentrations of trace elements from stormflow samples were compared to the acute standards. Specifically, the acute standard used in this report for total arsenic was $50 \mu \mathrm{g} / \mathrm{L}$ and for dissolved selenium was $18.4 \mu \mathrm{g} / \mathrm{L}$. The acute standards for dissolved copper and zinc varied by site and were based on mean base-flow hardness. The acute standard for dissolved copper ranged from 16.5 to $34.0 \mu \mathrm{g} / \mathrm{L}$, and the acute standard for dissolved zinc ranged from 141 to $273 \mu \mathrm{g} / \mathrm{L}$. The Colorado Department of Public Health and Environment (2001a, 2001b) defined acute standard as the level not to be exceeded by a concentration in a single sample or by an 
Table 4. Correlations between various land uses and physical properties and selected water-quality constituents for sites in the Fountain and Monument Creek watersheds, 1998 through 2005.

[Note: correlation coefficients that are statistically significant and are greater than 0.6 are shown in bold. R, Spearman correlation coefficients; p-value, probability value; Q, streamflow; P_TOT, total phosphorus; SC, specific conductance; NH4_D, dissolved ammonia; NO2NO3_D, dissolved nitrite plus nitrate; E_COL, Escherichia coli; FC_COL, fecal coliform; BOD, 5-day biochemical oxygen demand]

\begin{tabular}{|c|c|c|c|c|c|c|c|}
\hline \multicolumn{8}{|c|}{ Total impervious area, in square miles } \\
\hline & Q & P_TOT & $\mathrm{SC}$ & NH4_D & NO2NO3_D & E_COL & FC_COL \\
\hline $\mathrm{R}$ & 0.88 & 0.72 & 0.63 & 0.44 & 0.36 & 0.06 & -0.04 \\
\hline $\mathrm{p}$-value & .0001 & .0001 & .0001 & .0001 & .0001 & .10 & .73 \\
\hline \multicolumn{8}{|c|}{ Total percent impervious area } \\
\hline & Q & P_TOT & $\mathrm{SC}$ & NH4_D & NO2NO3_D & E_COL & BOD \\
\hline $\mathrm{R}$ & 0.86 & 0.72 & 0.64 & 0.44 & 0.40 & 0.07 & 0.05 \\
\hline $\mathrm{p}$-value & .0001 & .0001 & .0001 & .0001 & .0001 & .06 & .29 \\
\hline \multicolumn{8}{|c|}{ Agricultural area, in square miles } \\
\hline & NO2NO3_D & NH4_D & P_TOT & BOD & E_COL & $\mathrm{SC}$ & FC_COL \\
\hline $\mathrm{R}$ & 0.58 & 0.188 & 0.15 & 0.14 & 0.12 & 0.10 & 0.04 \\
\hline $\mathrm{p}$-value & .0001 & .0001 & .0019 & .0036 & .0044 & .0215 & .97 \\
\hline \multicolumn{8}{|c|}{ Commercial area, in square miles } \\
\hline & Q & P_TOT & $\mathrm{SC}$ & NH4_D & NO2NO3_D & FC_COL & E_COL \\
\hline $\mathrm{R}$ & 0.77 & 0.69 & 0.60 & 0.42 & 0.37 & -0.07 & 0.06 \\
\hline $\mathrm{p}$-value & .0001 & .0001 & .0001 & .0001 & .0001 & .61 & .16 \\
\hline \multicolumn{8}{|c|}{ Industrial area, in square miles } \\
\hline & Q & P_TOT & $\mathrm{SC}$ & NH4_D & NO2NO3_D & E_COL & BOD \\
\hline $\mathrm{R}$ & 0.85 & 0.65 & 0.56 & 0.43 & 0.38 & 0.08 & 0.02 \\
\hline $\mathrm{p}$-value & .0001 & .0001 & .0001 & .0001 & .0001 & .04 & .70 \\
\hline \multicolumn{8}{|c|}{ Residential area, in square miles } \\
\hline & Q & P_TOT & $\mathrm{SC}$ & NO2NO3_D & NH4_D & E_COL & FC_COL \\
\hline $\mathrm{R}$ & 0.85 & 0.73 & 0.62 & 0.43 & 0.43 & 0.04 & -0.04 \\
\hline $\mathrm{p}$-value & .0001 & .0001 & .0001 & .0001 & .0001 & .34 & .78 \\
\hline \multicolumn{8}{|c|}{ Undeveloped area, in square miles } \\
\hline & Q & P_TOT & $\mathrm{SC}$ & NH4_D & NO2NO3_D & E_COL & BOD \\
\hline $\mathrm{R}$ & 0.84 & 0.73 & 0.64 & 0.44 & 0.39 & 0.08 & 0.06 \\
\hline $\mathrm{p}$-value & .0001 & .0001 & .0001 & .0001 & .0001 & .04 & .22 \\
\hline
\end{tabular}


average calculated from all samples collected during a 1-day period.

\section{Onsite Measurements of Specific Conductance, $\mathrm{pH}$, and Dissolved Oxygen}

Specific conductance, $\mathrm{pH}$, and dissolved oxygen were measured onsite concurrently with sample collection. Variations in specific conductance, $\mathrm{pH}$, and dissolved oxygen with respect to base flow, normal flow, and stormflow are shown in figures 4 and 5 .

\section{Specific Conductance}

Specific conductance, which is an indicator of dissolved solids, generally decreased as streamflow increased. In general, the largest specific-conductance values occurred during base flow and, as a result of dilution, they were smaller during stormflow (fig. 4). Spatially, specific conductance tended to increase in a downstream direction. The largest spatial specific-conductance increases occurred during base flow and normal flow between Fountain Creek sites 07103700 (FoCr_Manitou) and 07103707 (FoCr_8th), upstream from the confluence with Monument Creek, which indicates a relatively large source of dissolved solids (fig. 4A). This increase also is a reflection of the reduced streamflow at site 07103707 (FoCr_8th); median streamflow during normal-flow conditions for the period 1998 through 2006 decreased from $15 \mathrm{ft}^{3} / \mathrm{s}$ at site 07103700 (FoCr_Manitou) to $3 \mathrm{ft}^{3} / \mathrm{s}$ at site 07103707 (FoCr_8th), a result of streamflow diversions that occur between the two sites. Specific conductance in Monument Creek and the tributaries draining to it ranged from less than 100 to more than 2,000 $\mu \mathrm{S} / \mathrm{cm}$ during base-flow and normalflow conditions. Median specific-conductance concentrations for base-flow and normal-flow conditions generally ranged from 400 to $700 \mu \mathrm{S} / \mathrm{cm}$, with the exception of two tributary sites, 07103985 (TbCo) and $07104050(\mathrm{RkCr})$, tributaries to Cottonwood Creek and Monument Creek, respectively (fig. 4B). Site 07103985 (TbCo), a tributary to Cottonwood Creek, generally had specific-conductance values larger than $1,000 \mu \mathrm{S} / \mathrm{cm}$ during base flow and normal flow, which generally were 50 percent larger than values measured at other sites. Median specific-conductance concentrations at site $07104050(\mathrm{RkCr})$ were 2 to 4 times larger than concentrations at most other tributaries, but the elevated concentrations probably are a result of the concentrating effects of low flows. Median flow at site 07104050 (RkCr) during normal flow was $0.07 \mathrm{ft}^{3} / \mathrm{s}$ and generally was less than $0.1 \mathrm{ft}^{3} / \mathrm{s}$. One other tributary site, $07105600(\mathrm{SaCr})$, had elevated specific-conductance values compared to other sites in the watershed. The median specific-conductance value during normal flow was $1,250 \mu \mathrm{S} / \mathrm{cm}$ at site $07105600(\mathrm{SaCr})$. Although specific-conductance values are relatively high in Sand Creek above the mouth, median discharge measured at this location was $3.0 \mathrm{ft}^{3} / \mathrm{s}$ during normal flow compared to about $100 \mathrm{ft}^{3} / \mathrm{s}$ in Fountain Creek near the confluence with Sand Creek; therefore, the overall effect of specific conductance in Sand Creek to Fountain Creek is small.

\section{$\mathrm{pH}$ and Dissolved Oxygen}

During 1998 through 2006, median values of $\mathrm{pH}$ generally ranged from about 7.8 to $8.4 ; \mathrm{pH}$ values measured during stormflows generally were smaller than during base flows and normal flows (fig. 5A). However, all measurements were well within the acceptable range for the in-stream standard for $\mathrm{pH}$. The Colorado in-stream water-quality standard range for $\mathrm{pH}$ is 6.5 to 9.0 .

Median dissolved-oxygen concentrations were consistently larger during base-flow conditions because the colder water temperatures that occur during the winter months allow more oxygen to stay in solution. Dissolvedoxygen concentrations generally were larger than $6 \mathrm{mg} / \mathrm{L}$ and were similar for normal flow and stormflow at most sites (fig. 5B). Another analysis used to measure oxygen content in water is percent saturation of dissolved oxygen; it is a measure of the amount of oxygen dissolved in water compared to the maximum amount that could be present at the same temperature and is determined from dissolved-oxygen concentrations, water temperature, and barometric pressure. At all main-stem and tributary sites in Fountain and Monument Creeks, percent saturation of dissolved oxygen generally was larger than 90 percent during all flow conditions, which indicated well-oxygenated streams (fig. 5C). The one exception occurred at Sand Creek, site 07105600 $(\mathrm{SaCr})$, during normal-flow conditions. The percent saturation of dissolved oxygen at this site ranged from 65 to 94 percent and the median value was 80 percent.

\section{Biochemical 0xygen Demand}

Biochemical oxygen demand measures the concentration of biodegradable organic matter present in a sample of water. It can be used to infer the general quality of the water and its degree of pollution by biodegradable organic matter. BOD is an indicator of the quality of a water body and commonly is measured over a 5-day period and referred to as $\mathrm{BOD}_{5}$. There is no in-stream water-quality standard for $\mathrm{BOD}_{5}$ in the Fountain and Monument Creek watersheds. However, typical $\mathrm{BOD}_{5}$ values for pristine rivers generally are less than $1 \mathrm{mg} / \mathrm{L}$, and typical $\mathrm{BOD}_{5}$ values from three-stage treated municipal sewage is about $20 \mathrm{mg} / \mathrm{L}$ (Shelton, 1991).

\section{Biochemical Oxygen Demand Concentrations during 1998 through 2006}

$\mathrm{BOD}_{5}$ samples, as previously stated, were collected only at main-stem sites. $\mathrm{BOD}_{5}$ concentrations at all main-stem sites during 1998 through 2006 generally were larger during stormflow than during base flow and normal flow (fig. 6A). 

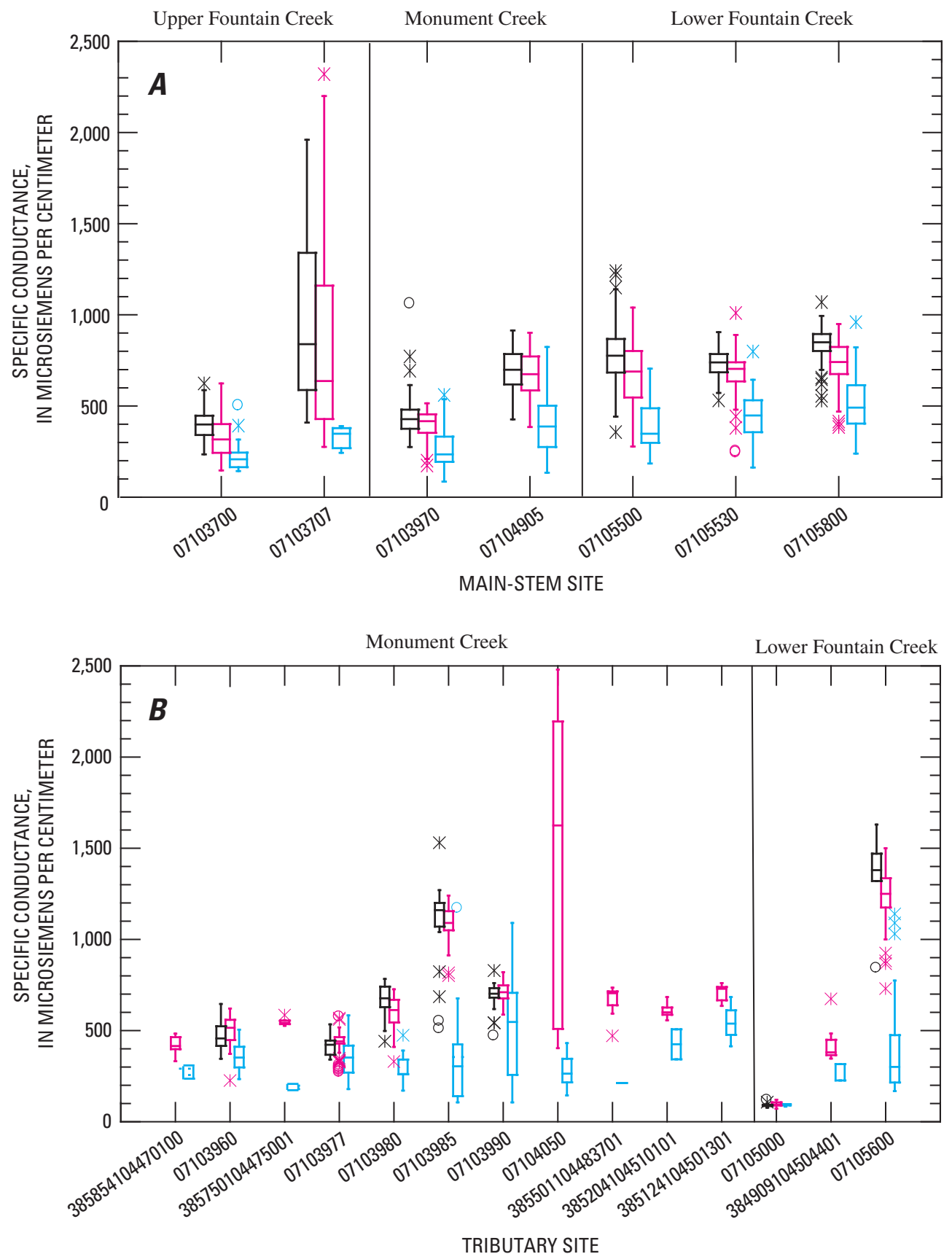

EXPLANATION

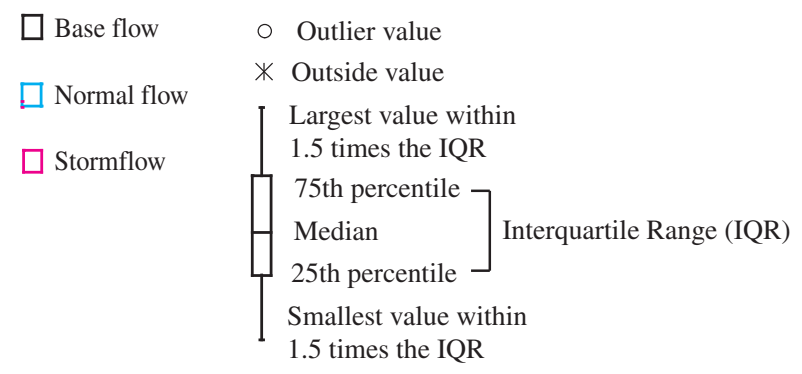

Figure 4. Variations in specific conductance at $(A)$ main-stem sites and $(B)$ tributary sites for base flow, normal flow, and stormflow in Fountain and Monument Creek watersheds, 1998 through 2006. 

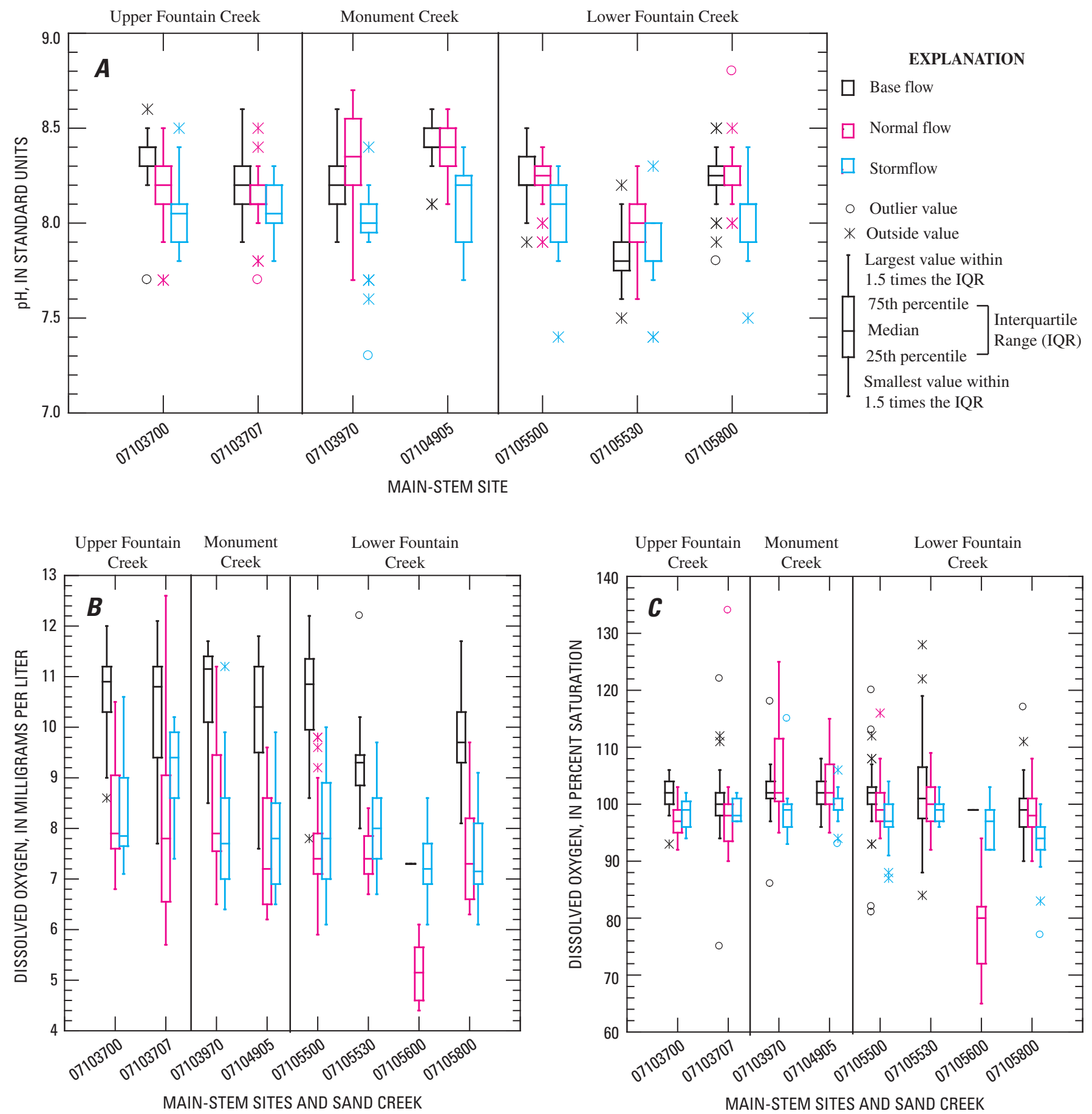

Figure 5. Variations in $(A) \mathrm{pH},(B)$ dissolved oxygen concentrations, and $(C)$ percent saturation of dissolved oxygen at main-stem sites and Sand Creek for base flow, normal flow, and stormflow in Fountain and Monument Creek watersheds, 1998 through 2006. 
Median $\mathrm{BOD}_{5}$ concentrations during stormflow ranged from 1.0 to $10.3 \mathrm{mg} / \mathrm{L}$ compared with a range of 1.0 to $5.9 \mathrm{mg} / \mathrm{L}$ during base flow. $\mathrm{BOD}_{5}$ concentrations in upper Fountain Creek, upstream from the Fountain-Monument Creek confluence, generally were similar to concentrations in Monument Creek (fig. 6A). Downstream from the confluence of Fountain and Monument Creeks the range of $\mathrm{BOD}_{5}$ concentrations were larger: concentrations ranged from 1.0 to $17 \mathrm{mg} / \mathrm{L}$ during base-flow and normal-flow conditions to between 1.0 and $26 \mathrm{mg} / \mathrm{L}$ during stormflow conditions. $\mathrm{BOD}_{5}$ concentrations tended to increase more at downstream sites 07105530 (FoCr_Janitell) and 07105800 (FoCr_Security), both located downstream from wastewater treatment-plant effluents, than at other main-stem sites during base flow and normal flow. Median base-flow and normal-flow concentrations at these two sites, 07105530 (FoCr_Janitell) and 07105800

(FoCr_Security), were similar. $\mathrm{BOD}_{5}$ concentrations measured during stormflow at site 07105800 (FoCr_Security) generally were larger than site 07105530 (FoCr_Janitell), indicating either additional sources of organic matter during stormflow or organically enriched streambed sediments were resuspended during stormflow. Median stormflow $\mathrm{BOD}_{5}$ concentrations at site 07105530 (FoCr_Janitell) and site 07105800

(FoCr_Security) were 4.0 and $10.3 \mathrm{mg} / \mathrm{L}$, respectively.

\section{Comparison of Biochemical Oxygen Demand Concentrations between 1981 through 1997 and 1998 through 2006}

Differences in $\mathrm{BOD}_{5}$ concentrations between 1981 through 1997 and 1998 through 2006 were evaluated at selected main-stem sites using a Kruskal-Wallis test to determine if the differences were statistically significant. Significant differences in $\mathrm{BOD}_{5}$ concentrations were evident at sites in Fountain Creek, both upstream and downstream from the confluence with Monument Creek. Two sites, 07103700 (FoCr_Manitou) and 07105530 (FoCr_Janitell), showed significant differences in $\mathrm{BOD}_{5}$ between 1981 through 1997 and 1998 through 2006 under all flow regimes. Median concentrations of $\mathrm{BOD}_{5}$ at 07103700 (FoCr_Manitou) increased slightly between the two time periods during base flow and normal flow to $1.0 \mathrm{mg} / \mathrm{L}$; however, median stormflow concentrations increased between the two time periods from 0.9 to $3.4 \mathrm{mg} / \mathrm{L}$ (fig. $6 B$ ). A potential cause of this increase could be associated with human population growth and associated organic material that occurs as overland runoff to Fountain Creek.

Median $\mathrm{BOD}_{5}$ concentrations at site 07105530

(FoCr_Janitell) decreased significantly during all flow regimes between 1981 through 1997 and 1998 through 2006, and the range of concentrations also significantly decreased, including maximum and minimum concentrations. Between the two periods, median $\mathrm{BOD}_{5}$ concentrations at site 07105530 (FoCr_Janitell) during normal and stormflow conditions decreased 84 percent, from 12.5 to $2.0 \mathrm{mg} / \mathrm{L}$, and 62 percent, from 10.5 to $4.0 \mathrm{mg} / \mathrm{L}$, respectively. Changes in $\mathrm{BOD}_{5}$ concentration at site 07105530 (FoCr_Janitell) occurred in the early 1990s, and improvements to water quality are the result of treatment improvements made to the Las Vegas Street Wastewater Treatment Plant located upstream from site 07105530 (FoCr_Janitell) (fig. 6C).

\section{Bacteria}

Fecal coliform and E. coli were analyzed in streamflow samples. These bacteria are "indicator bacteria," which are used to represent a potential for pathogenicity of surface water. Although these bacteria generally are not toxic themselves, they are used to represent all viruses, protozoa, and pathogenic bacteria that may cause illnesses associated with water contact and ingestion (U.S. Environmental Protection Agency, 2004).

\section{Fecal Coliform Bacteria during 1998 through 2006}

Fecal coliform bacteria concentrations, during 1998 through 2006, were highly variable, generally varying by more than a factor of 10 between flow regimes at each site (fig. 7). Fecal coliform concentrations tended to be largest during stormflow and smallest during base flow. With the exception of site 07103707 (FoCr_8th) on Fountain Creek and site 07103970 (MoCr_Woodmen) on Monument Creek, median fecal coliform concentrations at all sites along the main-stem during periods of normal flow and stormflow were larger than $200 \mathrm{col} / 100 \mathrm{~mL}$ (fig. 7A). At all Fountain and Monument Creek sites, with the exception of 07103707 (FoCr_8th) on Fountain Creek, the median fecal coliform concentrations during stormflow were larger than $1,000 \mathrm{col} / 100 \mathrm{~mL}$, whereas during base-flow conditions the median fecal coliform concentrations at most main-stem sites in the watershed, with the exception of site 07105530 ( $\mathrm{FoCr}_{-}$ Janitell) in Fountain Creek, generally were smaller than $100 \mathrm{col} / 100 \mathrm{~mL}$.

Although the sample size is relatively small for the tributaries during stormflow, with the exception of the Bear Creek site 07105000 (upper_BeCr), median stormflow fecal coliform concentrations in tributaries were larger than $1,000 \mathrm{col} / 100 \mathrm{~mL}$ (fig. 7B). Two sites on Kettle Creek, a tributary to Monument Creek, sites 385854104470100 (upper_KeCr) and 07103960 (lower_KeCr), had median fecal coliform stormflow concentrations of 9,500 and $7,100 \mathrm{col} / 100 \mathrm{~mL}$, respectively, and concentrations ranged from about 300 to $140,000 \mathrm{col} / 100 \mathrm{~mL}$. The area around Kettle Creek is mostly agricultural; cattle manure has been observed in the creek, possibly accounting for the high concentrations. Median fecal coliform concentrations were elevated, exceeding 10,000 col/100 mL, at three other Monument Creek tributary sites during periods of stormflow from 1998 through 2006: sites 385750104475001 ( $\mathrm{PiCr}$ ), 07104050 (RkCr), and 385124104501301 (lower_MeCr) (fig. 7B). 

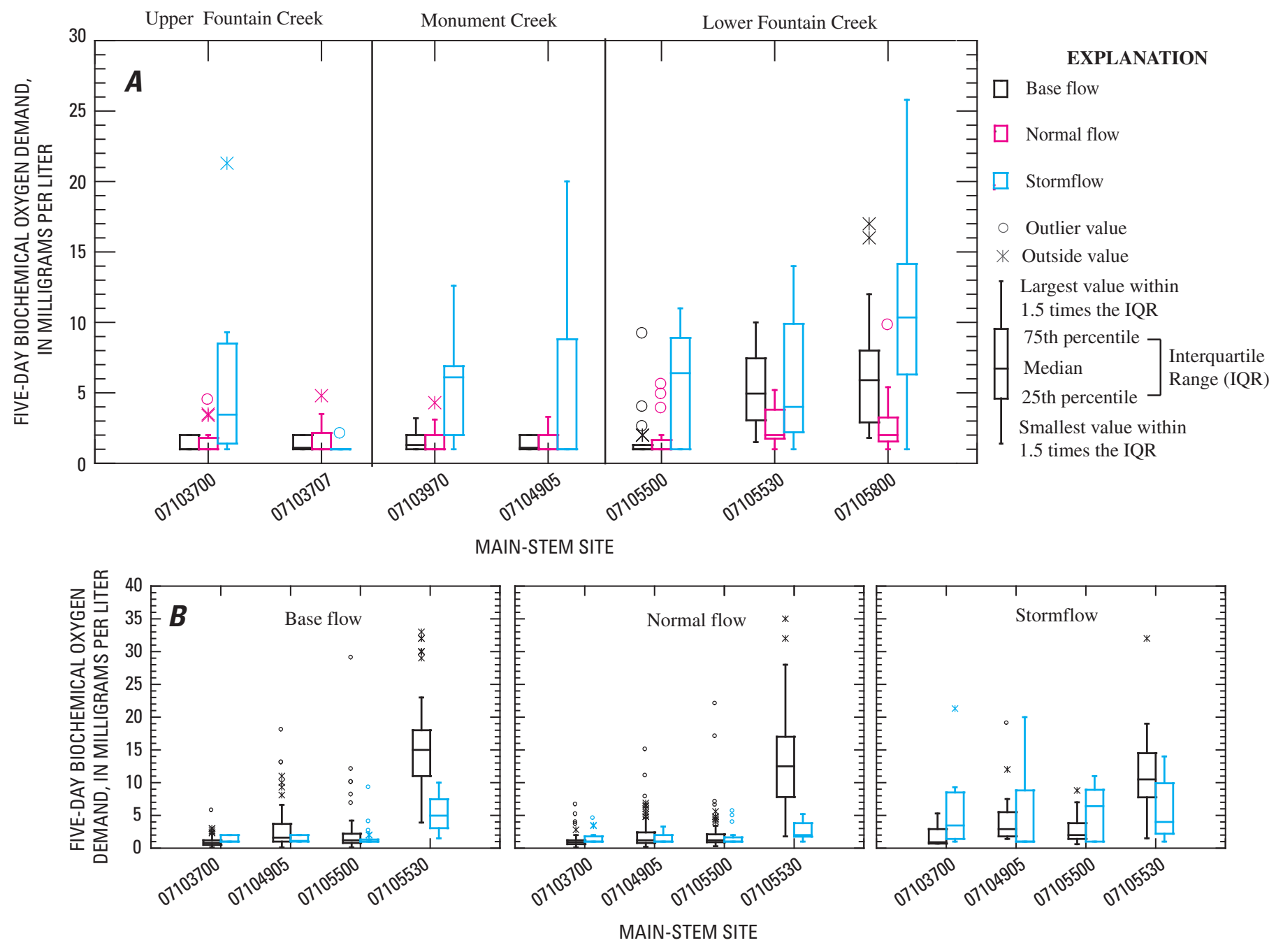

EXPLANATION
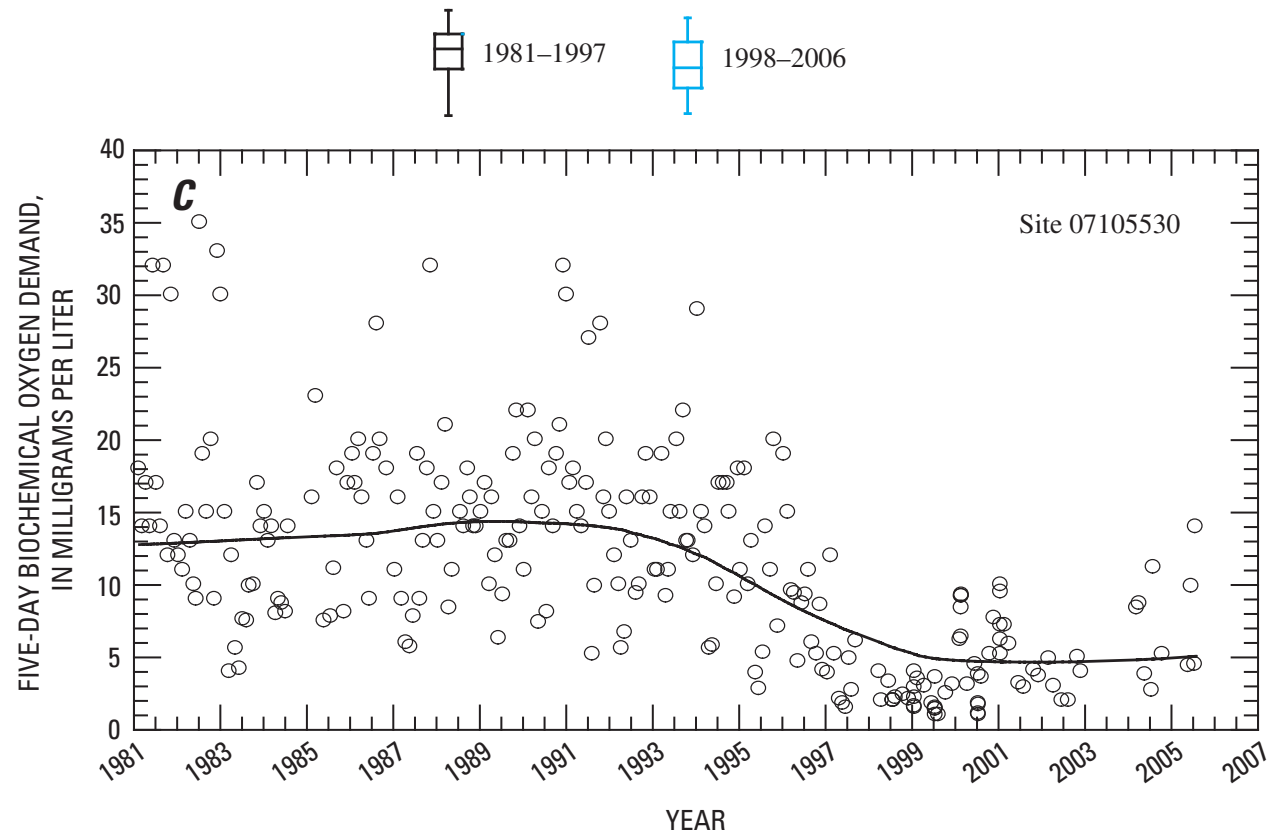

Figure 6. Variations in 5-day biochemical oxygen demand $\left(\mathrm{BOD}_{5}\right)$ for base flow, normal flow, and stormflow at $(A)$ main-stem sites in Fountain and Monument Creek watersheds, 1998 through 2006, $(B)$ a comparison of BOD ${ }_{5}$ concentrations between 1981 through 1997 and 1998 through 2006, and $(C)$ temporal variations in 5-day biochemical oxygen demand $\left(\mathrm{BOD}_{5}\right)$ at site 07105530. 

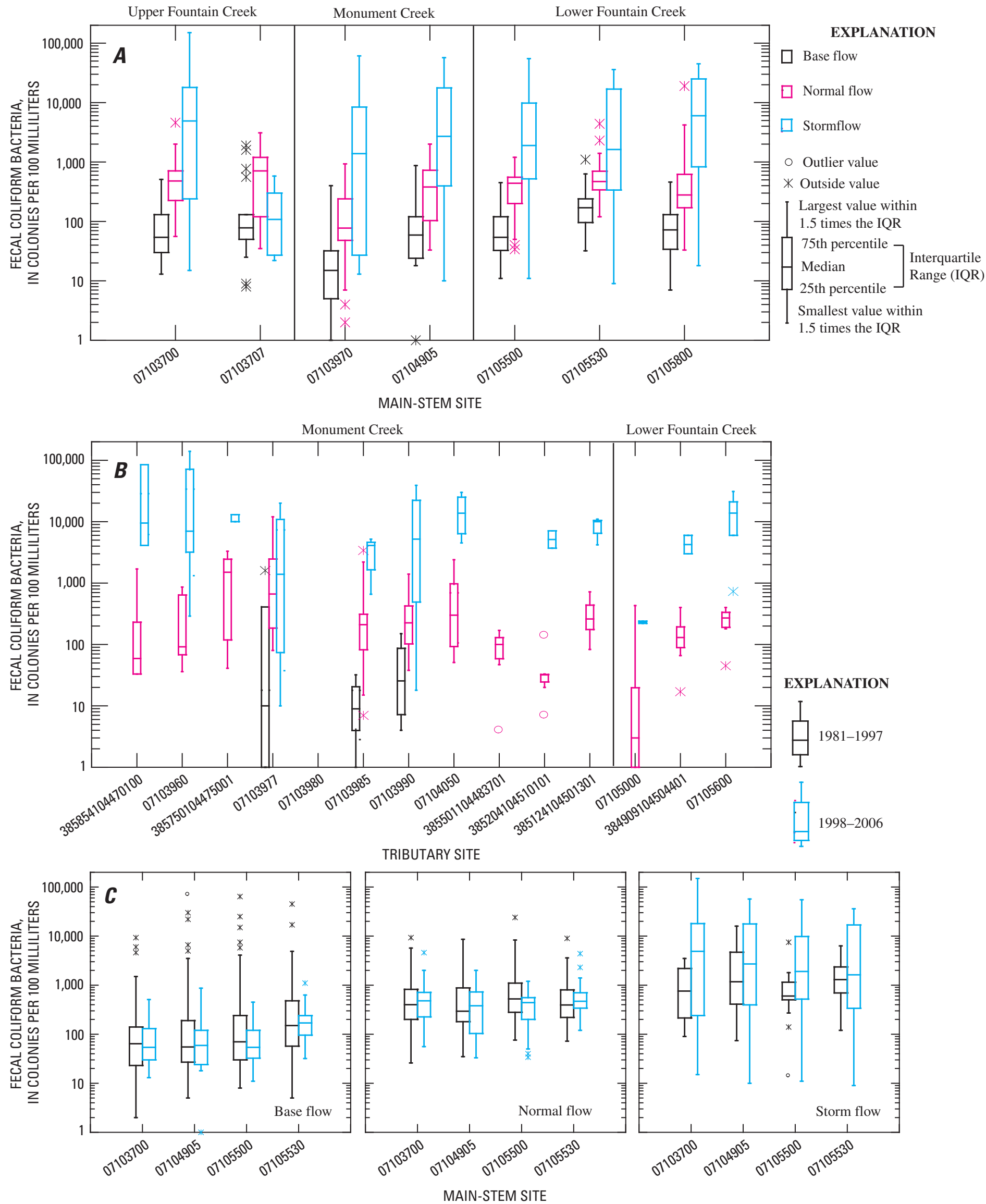

Figure 7. Variations in fecal coliform for base flow, normal flow, and stormflow at $(A)$ main-stem sites, $(B)$ tributary sites in Fountain and Monument Creek watersheds, 1998 through 2006, and (C) comparison of variations in fecal coliform between 1981 through 1997 and 1998 through 2006. 
Based on a small number of samples, fecal coliform concentrations during 1998 through 2006 also were elevated farther downstream on tributary site $07105600(\mathrm{SaCr})$, on Sand Creek, where median concentrations during normal-flow and stormflow conditions were 270 and 14,500 col/100 mL, respectively. Sand Creek drains a portion of urbanized area in Colorado Springs, but it is unclear what the sources of the elevated fecal coliform concentrations were at this location.

\section{Comparison of Fecal Coliform Concentrations between 1981 through 1997 and 1998 through 2006}

The Kruskal-Wallis statistical test was applied to the fecal coliform data to evaluate whether there were statistically significant differences in fecal coliform concentrations between 1981 through 1997 and 1998 through 2006 at selected main-stem sites (fig. 7C). Tributary sites were not sampled for fecal coliform prior to 1998 and, therefore, were not included in this analysis. Only one site in the watershed, 07105500 (FoCr_Nevada), showed statistically significant differences in fecal coliform concentrations. During normal flow, measured fecal coliform concentrations significantly decreased, and during stormflow, measured fecal coliform concentrations significantly increased between the two periods. Median fecal coliform concentrations decreased from 525 to $440 \mathrm{col} / 100 \mathrm{~mL}$ during normal flow and increased from 800 to $1,900 \mathrm{col} / 100 \mathrm{~mL}$ during stormflow. The site is downstream from the confluence of Fountain and Monument Creeks, so identification of source areas is difficult.

\section{Escherichia Coli (E. coli) Bacteria Concentrations}

Bacteria sampling for E. coli began in 2002. Similarly to fecal coliform concentrations, $E$. coli concentrations at each site, during 2003 through 2006, generally differed by a factor of 10 or more during all flow conditions (fig. 8). The smallest concentrations of $E$. coli were detected during periods of base flow and were largest during periods of stormflow. Median E. coli concentrations at main-stem sites during base flow were less than $100 \mathrm{col} / 100 \mathrm{~mL}$, whereas median E. coli concentrations during normal-flow and stormflow conditions were much larger, ranging between 80 and 660 $\mathrm{col} / 100 \mathrm{~mL}$ during normal-flow conditions and 1,300 to $17,000 \mathrm{col} / 100 \mathrm{~mL}$ during stormflow conditions (fig. 8A). Median E. coli concentrations during normal-flow and stormflow conditions at several sites exceeded the one-time primary contact standard of $235 \mathrm{col} / 100 \mathrm{~mL}$ bacteria used by CDPHE for E. coli (U.S. Environmental Protection Agency, 1986).

\section{Escherichia Coli (E. coli) Bacteria Concentrations at Tributary Sites}

Based on a small number of samples, E. coli concentrations also exceeded the $235-\mathrm{col} / 100 \mathrm{~mL}$ standard at many tributary sites during periods of normal flow and stormflow (fig. 8B). Median concentrations at three sites on tributaries to Monument Creek were particularly elevated during normal-flow and stormflow conditions: site 385750104475001 (PiCr) on Pine Creek, site 07103977 (upper_CoCr) on Cottonwood Creek, and site 07104050 (RkCr) on North Rockrimmon Creek. Median normalflow concentrations were 715, 430, and $230 \mathrm{col} / 100 \mathrm{~mL}$, respectively. The Pine Creek and Cottonwood Creek sites are located in rural areas where cattle and horses are present, and it is possible that manure may be a major source of the elevated E. coli concentrations. Site 07104050 (RkCr) on North Rockrimmon Creek is urbanized and, based on the few data sampled at this site, it is unclear what may be causing the increased E. coli concentrations. Farther downstream, median E. coli concentrations at Sand Creek at site $07105600(\mathrm{SaCr})$ were elevated during both normal-flow and stormflow periods and, as with fecal coliform, it is unknown what specific sources caused the large concentrations.

\section{Nitrogen and Phosphorus}

Nitrogen and phosphorus samples were collected from seven main-stem sites between 1998 and 2006 and at 14 tributary sites beginning in 2003 (figs. 9 and 10).

\section{Dissolved Nitrite plus Nitrate}

Concentrations of dissolved nitrite plus nitrate (hereinafter referred to as "nitrite plus nitrate") were larger at two sites on Cottonwood Creek, a tributary to Monument Creek, than at other nearby sites: 07103985 (TbCo) and 07103990 (lower_CoCr) (fig. 10). The in-stream water-quality standard for nitrate is $10 \mathrm{mg} / \mathrm{L}$ (Colorado Department of Public Health and Environment, 2006). During base-flow and normal-flow conditions, the median concentrations of nitrite plus nitrate at these two sites ranged from 5.1 to $6.1 \mathrm{mg} / \mathrm{L}$ and were 4 to 7 times larger than concentrations at the nearest upstream site on Monument Creek, site 07103970 (MoCr_Woodmen) (figs. 9 and 10). Median stormflow concentrations of nitrite plus nitrate ranged from 0.93 to $2.6 \mathrm{mg} / \mathrm{L}$ at these two sites (figs. 9 and 10). Median streamflow at site 07103985 ( $\mathrm{TbCo}$ ) during normal-flow conditions was less than $1.0 \mathrm{ft}^{3} / \mathrm{s}$, but during stormflow periods it was measured as large as $84 \mathrm{ft}^{3} / \mathrm{s}$. The source of these larger nitrite plus nitrate concentrations has not been identified, 

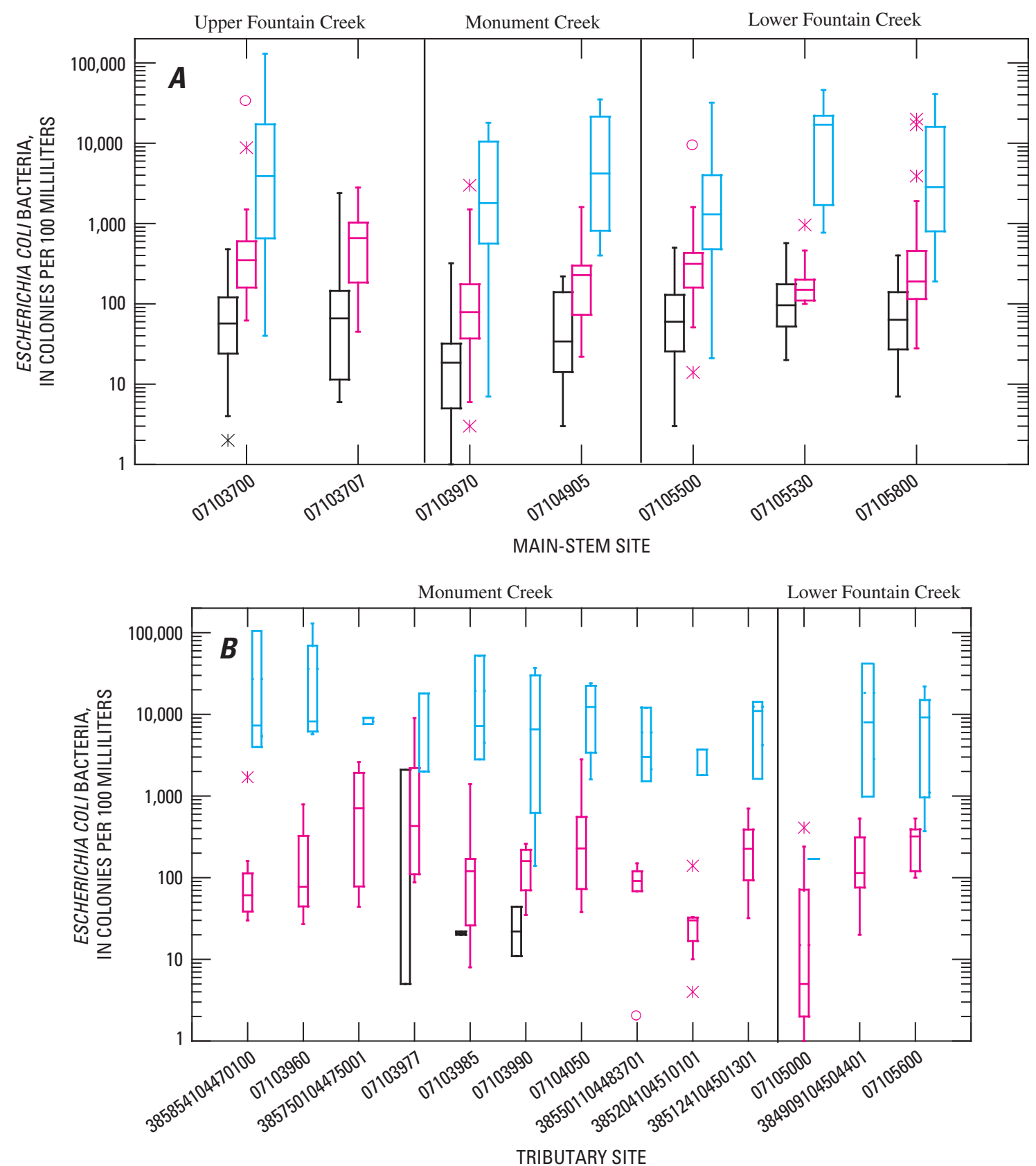

EXPLANATION

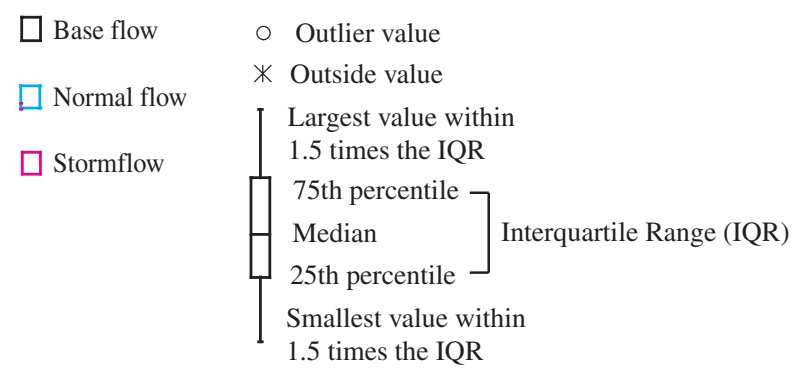

Figure 8. Variations in Escherichia coli (E. coli) for base flow, normal flow, and stormflow at $(A)$ main-stem sites, and $(B)$ tributary sites in Fountain and Monument Creek watersheds, 1998 through 2006. 

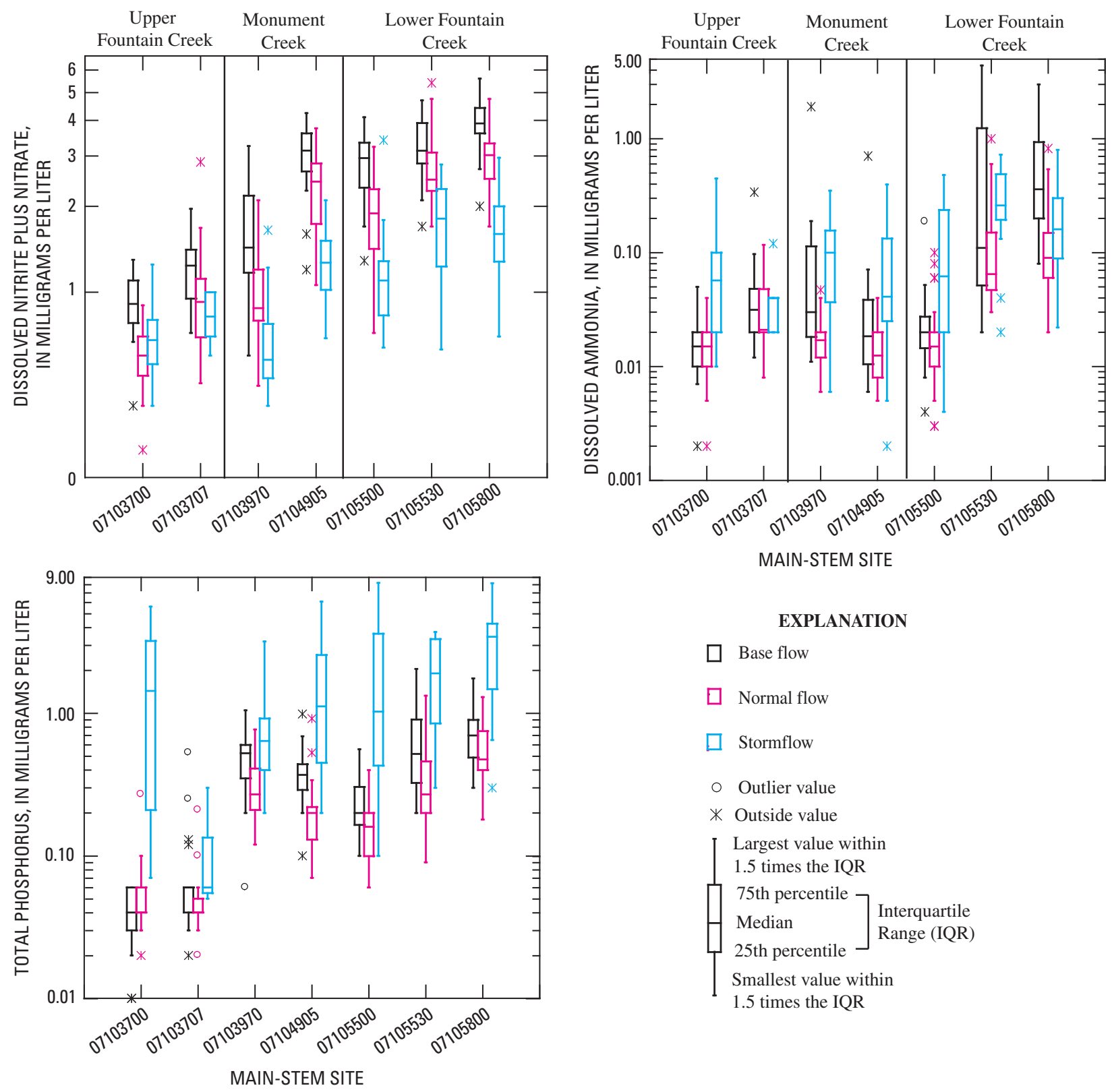

Figure 9. Variations in nitrogen and phosphorus concentrations at main-stem sites for base flow, normal flow, and stormflow in the Fountain and Monument Creek watersheds, 1998 through 2006. 

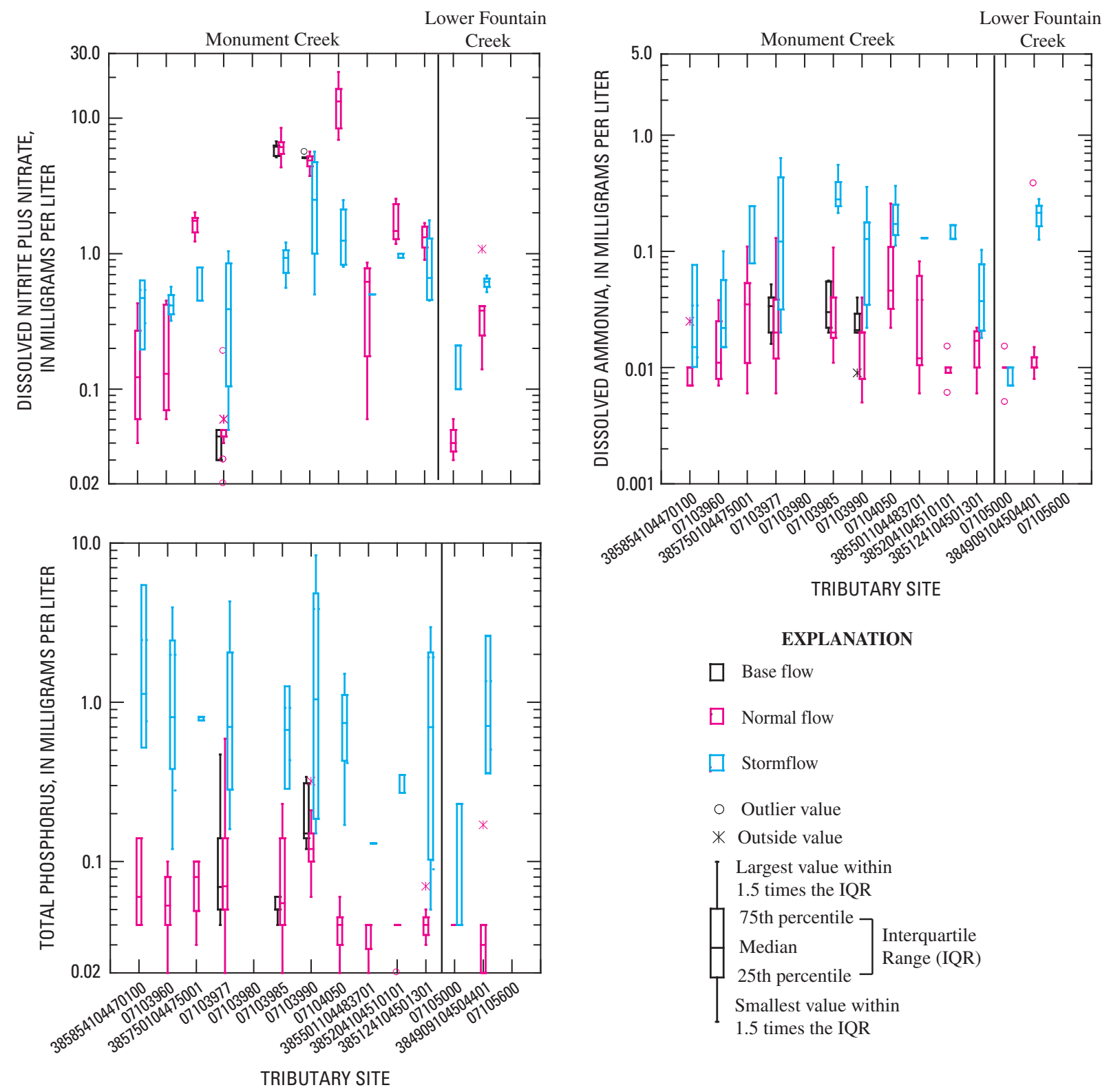

Figure 10. Variations in nitrogen and phosphorus concentrations at tributary sites for base flow, normal flow, and stormflow in the Fountain and Monument Creek watersheds, 1998 through 2006. 
but the fact that all measurements had elevated nitrite plus nitrate concentrations indicates a constant source. Median normal-flow concentrations of nitrite plus nitrate at a tributary site to Monument Creek, site 07104050 (RkCr), also were large. Although a small number of samples were collected at this site, the median nitrite plus nitrate concentration was $13.3 \mathrm{mg} / \mathrm{L}$, and concentrations ranged from about $7.0 \mathrm{mg} / \mathrm{L}$ to about $22.0 \mathrm{mg} / \mathrm{L}$. As previously mentioned, site 07104050 is located in an urbanized area, and the cause of the elevated concentrations is unclear.

\section{Total Phosphorus}

Median total phosphorus concentrations in Fountain Creek, upstream from the Monument Creek confluence, tended to be larger during stormflow and smaller during base-flow and normal-flow conditions (fig. 9). Median total phosphorus concentrations during base-flow and normal-flow conditions at site 07103700 (FoCr_Manitou) were 0.04 mg/L compared to $1.44 \mathrm{mg} / \mathrm{L}$ during stormflow conditions-more than 30 times larger than during base flow and normal flow. At site 07103707 (FoCr_8th), downstream from site 07103700 (FoCr_Manitou), median total phosphorus concentrations were much smaller and ranged from 0.04 to $0.06 \mathrm{mg} / \mathrm{L}$ depending on flow regime (fig. 9). Median total phosphorus concentrations at sites 07103970 (MoCr_Woodmen) and 07104905 (MoCr_Bijou) during stormflow conditions were 2.4 to 5.6 times larger than concentrations during base-flow and normal-flow conditions, respectively.

\section{Effect of Wastewater Treatment Plants}

Between sites 07105500 (FoCr_Nevada) and 07105530 (FoCr_Janitell), during 1998 through 2006, median concentrations of dissolved nitrite plus nitrate, dissolved ammonia, and total phosphorus increased substantially downstream from the Las Vegas Street Wastewater Treatment Plant (fig. 1; fig. 9). The upstream to downstream increase was most pronounced during base flow and normal flow but also was evident during stormflow for all nutrients analyzed. Median nutrient concentrations continued to increase between sites 07105530 (FoCr_Janitell) and 07105800 (FoCr_Security), downstream from the Security Wastewater Treatment Plant, during periods of base flow and normal flow. Median total phosphorus concentrations during stormflow increased almost 80 percent, from 1.9 to $3.4 \mathrm{mg} / \mathrm{L}$ between these two sites (fig. 9).

\section{Comparisons of Nitrogen and Phosphorus Concentrations between 1981 through 1997 and 1998 through 2006}

Comparisons of nutrient data between 1981 through 1997 and 1998 through 2006 indicated that at certain sites nutrient concentrations were statistically different between 1981 through 1997 and 1998 through 2006 (fig. 11). For instance, median nitrite plus nitrate concentrations significantly decreased for all flow regimes at site 07104905 (MoCr_Bijou) from 1981 through 1997 to 1998 through 2006. Significant decreases occurred in dissolved ammonia and total phosphorus concentrations for all flow regimes at site 07105530 (FoCr_Janitell) from 1981 through 1997 to 1998 through 2006. Median concentrations of dissolved ammonia decreased from 7.7 to $0.11 \mathrm{mg} / \mathrm{L}$ during base-flow conditions and from 5.5 to $0.06 \mathrm{mg} / \mathrm{L}$ during normal-flow conditions at site 07105530 (FoCr_Janitell). Similar results also were observed for total phosphorus. Median total phosphorus base-flow concentrations at site 07105530 (FoCr_Janitell) decreased from 5.1 to $0.52 \mathrm{mg} / \mathrm{L}$ (90-percent decrease) and from 4.4 to $0.27 \mathrm{mg} / \mathrm{L}$ (94-percent decrease) during normal flow, and the decreases at this site probably can be attributed to improvements in wastewater-treatment technology made to the Las Vegas Street Wastewater Treatment Plant.

\section{Trace Elements}

Trace elements are inorganic chemicals that usually occur in small amounts in nature. These include essential elements, such as zinc, potential essential elements such as manganese, and potentially toxic elements such as lead, which may also have some essential functions at low levels (World Health Organization, 1996). The trace elements analyzed for this report include total arsenic, dissolved boron, dissolved and total copper, total lead, total manganese, total nickel, dissolved and total selenium, and dissolved and total zinc.

Selenium is of concern in the Fountain Creek watershed because of its presence in both Fountain and Monument Creeks and the potential effects it may have on the aquatic environment. Selenium occurs naturally and is present in many sedimentary formations; however, it is commonly present in elevated amounts in marine formations of Tertiary and Cretaceous age and in soils derived from these formations (Seiler and others, 1999). Natural precipitation and irrigation water that infiltrates through these geologic formations and soils can oxidize selenium to soluble selenate $\left(\mathrm{SeO}_{4}{ }^{2-}\right)$ and, under proper hydrologic conditions, the mobilized selenium can be transported through irrigation drains and shallow ground-water movement and discharged to wildlife areas such as ponds, lakes, streams, and wetlands. In arid climates and terminal drainage basins, evaporation and transpiration can concentrate selenium in natural waters to toxic concentrations (Rowland and others, 2003).

Several dissolved trace-element concentrations associated with stormflow during 1998 through 2006 decreased or showed little change compared to base flow (fig. 12). Median stormflow concentrations of dissolved boron, dissolved copper, dissolved and total selenium, and dissolved zinc generally were smaller than base-flow and normal-flow concentrations. Median concentrations of total copper, lead, 

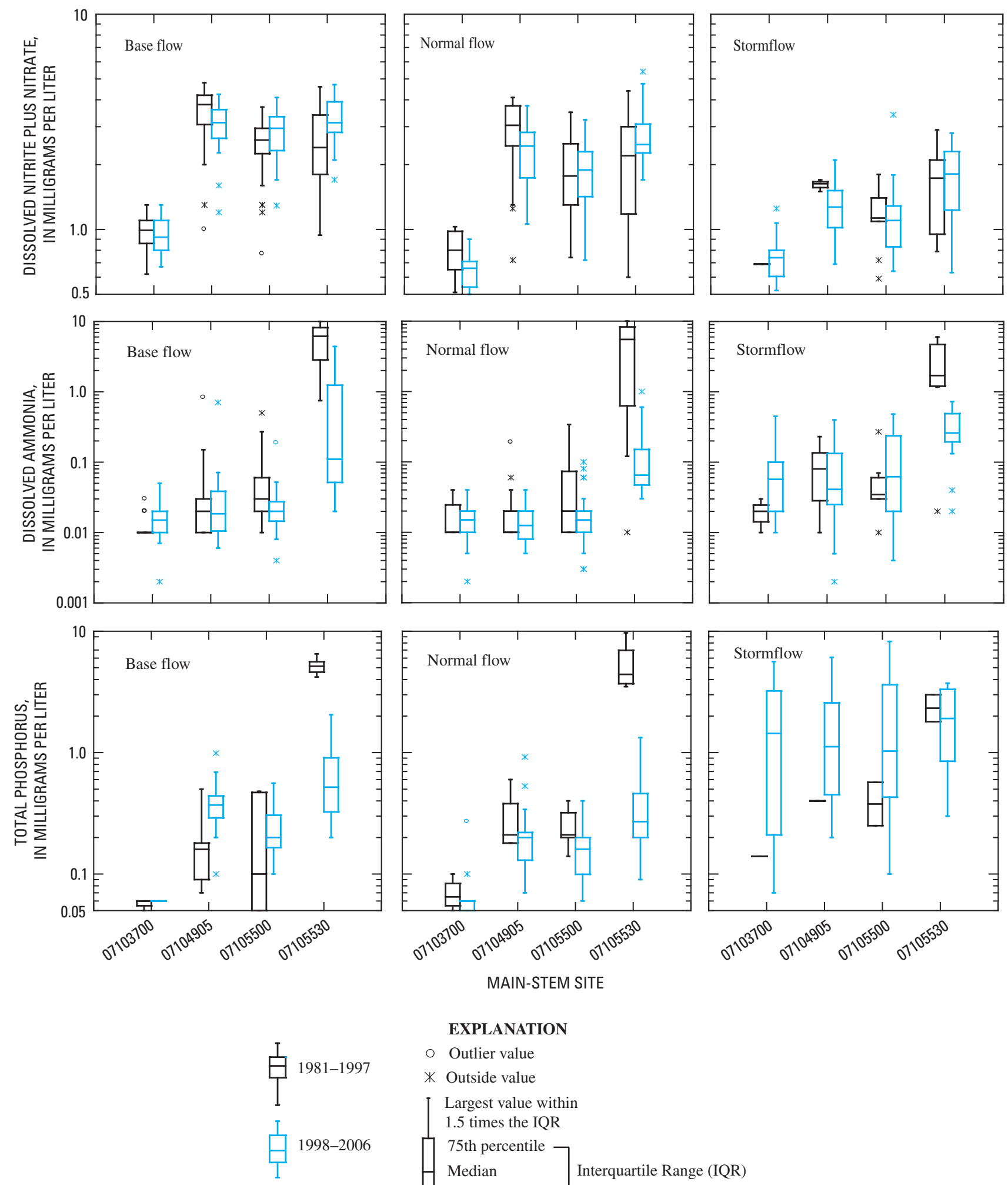

EXPLANATION

○ Outlier value

* Outside value

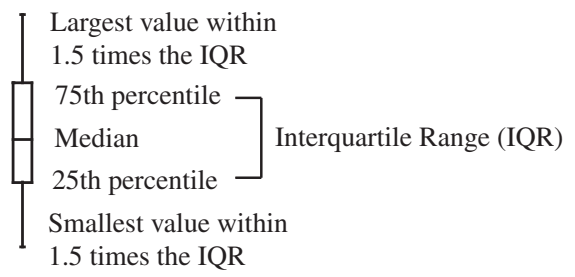

Figure 11. Variations in nitrite plus nitrate, ammonia, and phosphorus concentrations at selected sites between 1981 through 1997 and 1998 through 2006 for base flow, normal flow, and stormflow in the Fountain and Monument Creek watersheds. 

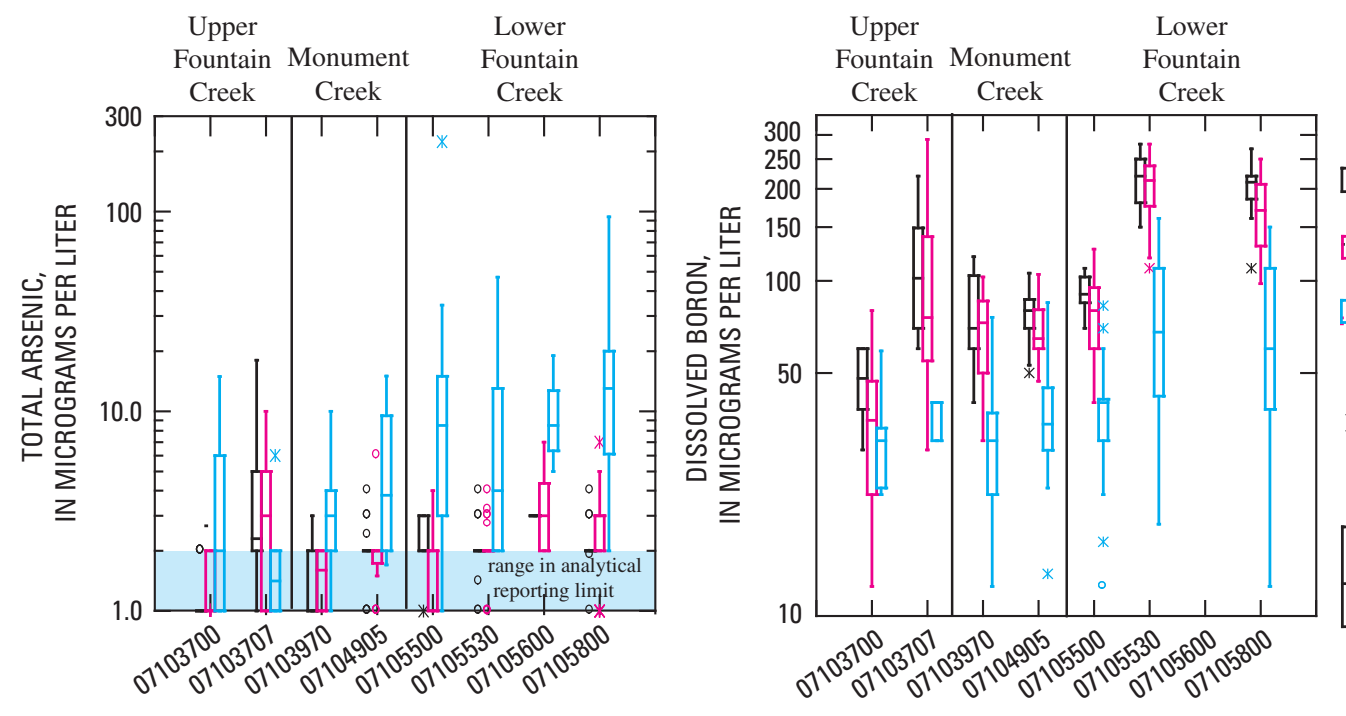

\section{EXPLANATION}
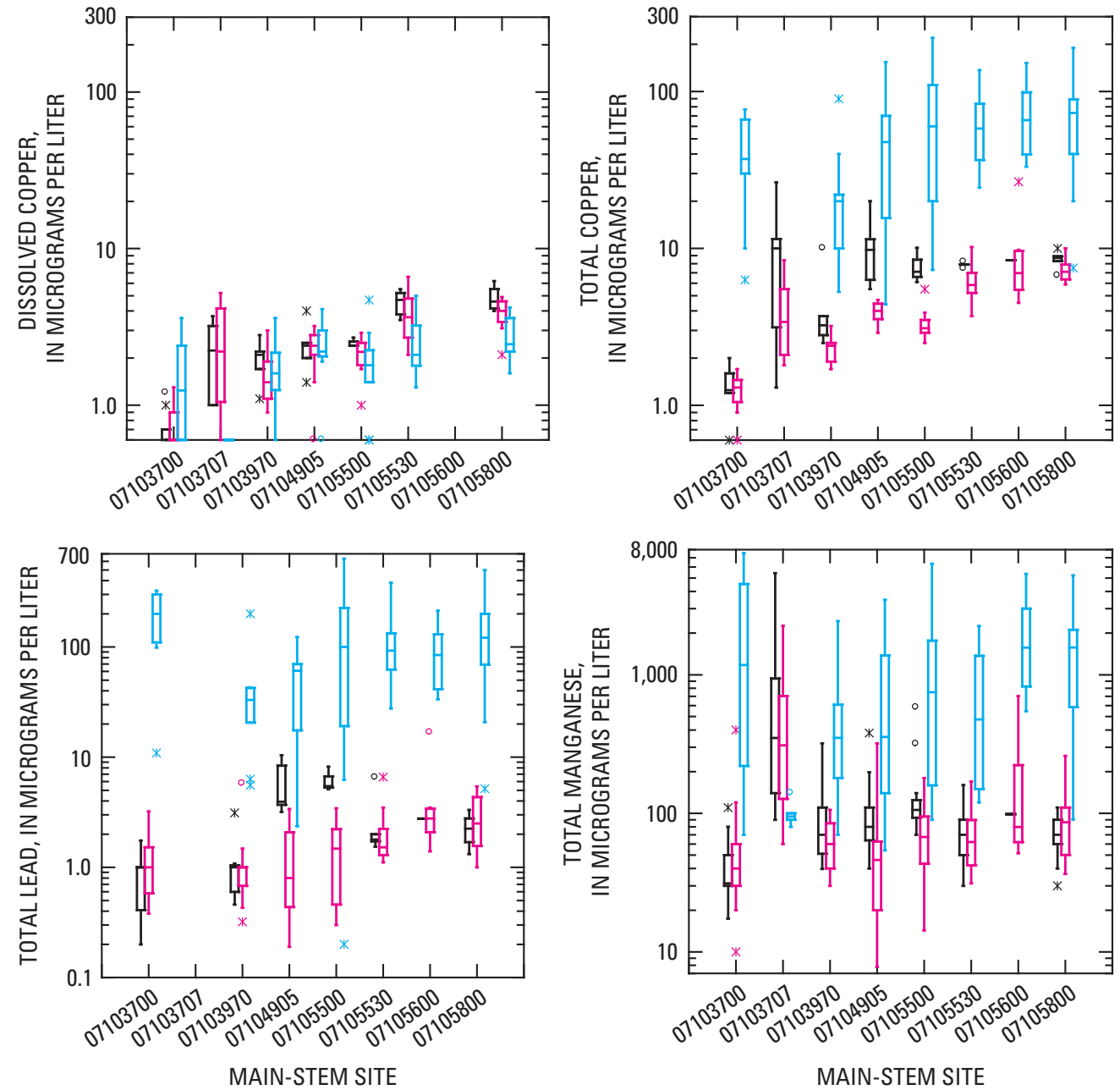

Figure 12. Variations in arsenic, boron, copper, lead, and manganese at main-stem sites for base flow, normal flow, and stormflow in the Fountain and Monument Creek watersheds, 1998 through 2006. 

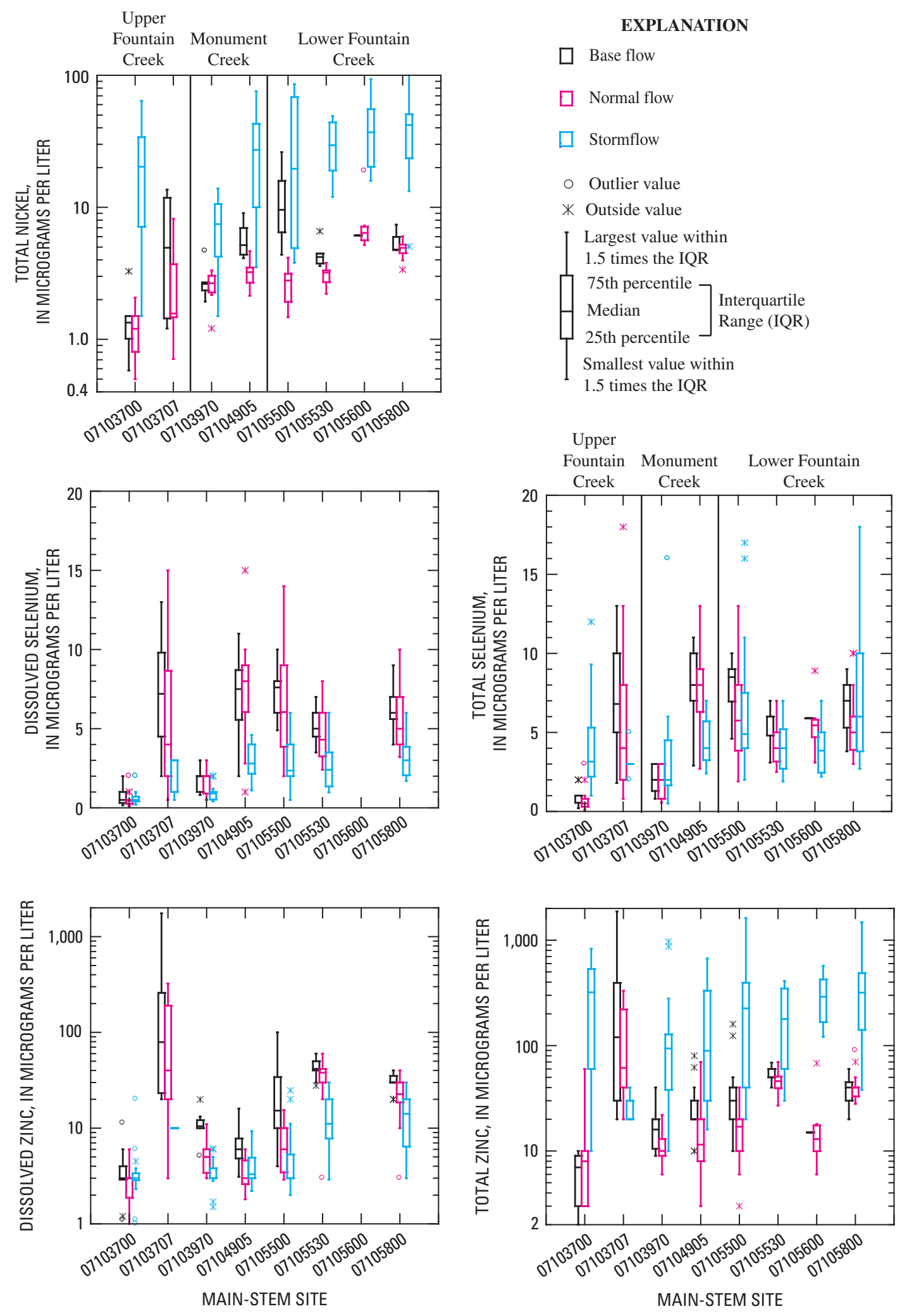

Figure 13. Variations in nickel, selenium and zinc at main-stem sites for base flow, normal flow, and stormflow in the Fountain and Monument Creek watersheds, 1998 through 2006. 
manganese, nickel, and zinc for stormflow samples generally were much larger than nonstormflow samples (figs. 12 and 13). However, concentrations of the dissolved phase of these trace elements were low during stormflow, indicating that these trace elements are transported in the particulate phase and are sorbed to sediments during stormflow.

\section{Main-Stem Trace-Element Concentrations from 1998 through 2006}

Large differences in median base-flow concentration in several trace elements were apparent between Fountain Creek sites 07103700 (FoCr_Manitou) and 07103707 (FoCr_8th), upstream from the confluence with Monument Creek. Concentrations of dissolved and total copper, total manganese, total nickel, dissolved and total selenium, and dissolved and total zinc ranged from 3 to 27 times larger at site 07103707 (FoCr_8th) than site 07103700 (FoCr_Manitou) during base flow, indicating a large source of trace elements between these two sites (figs. 12 and 13). The acute in-stream water-quality standard for dissolved zinc, based on base-flow conditions, was exceeded three times during 1998 through 2006. There were no other trace-element water-quality exceedances at this site or any other sites in the watershed. Median total selenium concentrations during base flow and normal flow increased from 1.0 to 6.8 micrograms per liter $(\mu \mathrm{g} / \mathrm{L})$ and 0.50 to $4.0 \mu \mathrm{g} / \mathrm{L}$, respectively, between sites 07103700 (FoCr_Manitou) and 07103707 (FoCr_8th). The likely source area is Gold Hill Mesa, a former tailings pile for a gold refinery located just upstream from the confluence with Monument Creek, and upstream from site 07103707 (FoCr_8th). Gold Hill Mesa currently (2007) is being developed under an approved VCUP (Colorado Voluntary Cleanup Program) plan (Colorado Department of Public Health and Environment, 2003). The VCUP plan is a process authorized by the State of Colorado and the USEPA to have landowners create a plan that would mitigate the environmental concerns for a property with known contaminants (L. Ross, Colorado Springs City Engineering, written commun., 2007). There also have been channel changes made to Fountain Creek in the vicinity of Gold Hill Mesa that may have disturbed stream sediments, resulting in periodic downstream transport of sediment and trace elements. As previously mentioned, streamflow from Fountain Creek is diverted downstream from site 07103700 (FoCr_Manitou) and upstream from Gold Hill Mesa, causing a reduction in flow; the median normal flow decreased from $15.0 \mathrm{ft}^{3} / \mathrm{s}$ to $3.2 \mathrm{ft}^{3} / \mathrm{s}$, and the result of this diversion reduces the dilution capacity for dissolved trace elements.

Concentrations of several trace elements increased upstream to downstream during 1998 through 2006 between upper Monument Creek at site 07103970 (MoCr_Woodmen) and lower Monument Creek at site 07104905 (MoCr_Bijou) and continued to increase in Fountain Creek downstream from the confluence with Monument Creek (figs. 12 and 13). These trends were statistically significant for total arsenic, dissolved boron, dissolved and total copper, total lead, total nickel, and dissolved and total selenium. Median concentrations of total copper, total lead, and total nickel concentrations more than doubled during periods of base flow between Monument Creek at site 07103970 (MoCr_Woodmen) and lower Monument Creek at site 07104905 (MoCr_Bijou), and median concentrations of dissolved and total selenium increased by 3 to 5 times between the same two sites during periods of base flow and normal flow. These increases could be attributed to a combination of geologic influences from the streambed along with the contribution from urban runoff. Peak dissolved and total selenium concentrations occurred in 2001 and have been declining in recent years.

Farther downstream in Fountain Creek, stormflow concentrations for total copper, lead, manganese, nickel, and zinc were larger at site 07105800 (FoCr_Security) than 07105530 (FoCr_Janitell), compared with other main-stem sites, and indicate a relatively large source of these metals between the two sites (figs. 12 and 13). Similar patterns for total copper, lead, nickel, and zinc were observed during the previous permit period, 1998 through 2002 (Edelmann and others, 2002), indicating that the source area is still contributing trace metals downstream from site 07105530 (FoCr_Janitell), although in some cases median stormflow concentrations have declined slightly since 1998 .

\section{Sand Creek Trace-Element Concentrations from 2003 through 2006}

Total concentrations of selected trace elements were sampled, beginning in 2003, at tributary site 07105600 $(\mathrm{SaCr})$ (figs. 12 and 13). The site is located downstream from Fountain Creek site 07105530 (FoCr_Janitell). During stormflow, concentrations of total arsenic, copper, manganese, nickel, and zinc were 20 to 1,000 percent larger at site $07105600(\mathrm{SaCr})$ than at site 07105530 (FoCr_Janitell), with the largest differences occurring for total manganese; median stormflow concentrations of total manganese increased from $477 \mu \mathrm{g} / \mathrm{L}$ at site 07105530 (FoCr_Janitell) to $1,725 \mu \mathrm{g} / \mathrm{L}$ at site $07105600(\mathrm{SaCr})$. The elevated median trace-element concentrations from Sand Creek may be a large contributing factor to the elevated concentrations at downstream site 07105800 (FoCr_Security), although there may be other unidentified source areas. Also, as previously mentioned, annual differences in streamflow observed temporal and spatial differences in constituent concentrations may be related to temporal differences in streamflow. 


\section{Comparisons of Trace-Element Concentrations between 1981 through 1997 and 1998 through 2006}

Trace-element concentrations from 1981 through 1997 were compared to concentrations from 1998 through 2006 to determine whether trace-element concentrations had increased or decreased over time (figs. 14 and 15). Differences in measured streamflow between the two periods may partially explain some of the observed differences in trace-element concentrations. A Kruskal-Wallis test was applied to selected trace elements at sites where sufficient data were available from 1981 to 2006, and the test showed that there was a statistically significant decrease between 1981 through 1997 and 1998 through 2006 in total lead concentrations during base-flow and normal-flow conditions at most main-stem sites, but an increase in stormflow concentrations was noted over the same period. Statistically significant differences between 1981 through 1997 and 1998 through 2006 occurred at individual main-stem sites for trace elements such as copper, manganese, nickel, and zinc. The differences were especially significant at upper Fountain Creek site 07103700 (FoCr_Manitou) for total copper, total nickel, and total zinc during stormflow. Some of the differences in concentrations may be a result of differences in the magnitude of storms sampled between the two periods rather than temporal differences between the two periods. Median concentrations of total copper increased from $4 \mu \mathrm{g} / \mathrm{L}$ during 1981 through 1997 to $37 \mu \mathrm{g} / \mathrm{L}$ during 1998 through 2006. Similarly, median total nickel concentrations increased from 1.0 to $20 \mu \mathrm{g} / \mathrm{L}$ and median total zinc concentrations increased from 30 to $320 \mu \mathrm{g} / \mathrm{L}$ between 1981 through 1997 and 1998 through 2006, respectively. Total selenium concentrations also increased at most sites during the same period, and the increase was statistically significant for all flow regimes at site 07105500 (FoCr_Nevada).

\section{Comparison of Loads during Stormflow and Base-Flow and Normal-Flow Conditions}

Instantaneous loads in this report were computed by multiplying concentration data by streamflow and an appropriate conversion factor. Instantaneous loads provide an estimate of the mass of a constituent transported past a given site during a given time and were expressed in pounds per day (lb/d). In contrast to concentration data, instantaneous load calculations provide a perspective on the mass transport of water-quality constituents and are useful in estimating the amount of nonpoint and point sources contributing to water-quality contamination. However, the instantaneous loads presented were based on a small data set and may not represent the range in loads that occurred in the watershed.

Loads vary considerably as a result of changes in streamflow, constituent concentrations, or both. Large constituent loads occur in response to snowmelt and storms. Median streamflows associated with stormflow samples that were collected generally were between 3 to 5 times larger than base-flow and normal-flow streamflows for Fountain Creek upstream from Monument Creek, 5 to 6 times larger for Monument Creek, and 3 to 5 times larger for Fountain Creek downstream from Monument Creek (fig. 3). Instantaneous loads for base flows, normal flows, and stormflows were computed for nutrients and trace elements to characterize the relative quantity of these constituents transported in Fountain and Monument Creeks. Also, as described in an earlier section of this report, median base flow, normal flow, and stormflow generally were smaller at selected main-stem sites during 1981 through 1997 than 1998 through 2006; therefore, loads generally were smaller during 1981 through 1997 than 1998 through 2006.

\section{Nitrogen and Phosphorus Loads}

\section{Main-Stem Nitrogen and Phosphorus Loads}

Instantaneous nutrient loads varied considerably from site to site during 1998 through 2006, and stormflow loads generally were considerably larger than base-flow and normal-flow loads (figs. 16 and 17). In Fountain Creek upstream from the confluence with Monument Creek at site 07103700 (FoCr_Manitou), median dissolved ammonia loads ranged from about $0.7 \mathrm{lb} / \mathrm{d}$ during normal flow to about $16 \mathrm{lb} / \mathrm{d}$ during stormflow. Median total phosphorus loads at the same location ranged from less than $4.0 \mathrm{lb} / \mathrm{d}$ during normal flow to $275 \mathrm{lb} / \mathrm{d}$ during stormflow, almost 70 times larger during stormflow. In Monument Creek at site 07103970 (MoCr_Woodmen), median nitrite plus nitrate loads increased from about $90 \mathrm{lb} / \mathrm{d}$ during normal flow to more than $250 \mathrm{lb} / \mathrm{d}$ during stormflow. Median total phosphorus loads increased from less than $20 \mathrm{lb} / \mathrm{d}$ during normal flow to more than $260 \mathrm{lb} / \mathrm{d}$ during stormflow.

Loads increased downstream from the FountainMonument Creek confluence primarily because of the combined flows from both creeks, but also, in some cases, because nutrient concentrations were larger in lower Fountain Creek, downstream from the confluence, than in upper Fountain or Monument Creeks. Large increases in nutrient loading were particularly noticeable downstream from the Las Vegas Street Wastewater Treatment Plant, at site 07105530 (FoCr_Janitell). Nutrient loads increased, on average, more than 350 percent during stormflow between sites 07105500 (FoCr_Nevada), upstream from the plant and 07105530 (FoCr_Janitell), downstream from the plant (fig. 16).

\section{Tributary Nitrogen and Phosphorus Loads}

Tributaries contributed a large amount of the total nutrient load estimated at main-stem sites on Monument Creek during 1998 through 2006 (fig. 17). The combined median stormload contributions from sites 07103960 (lower_KeCr) and 385750104475001 ( $\mathrm{PiCr}$ ) to site 07103970 (MoCr_Woodmen) represented almost 30 to 60 percent of the total median load 

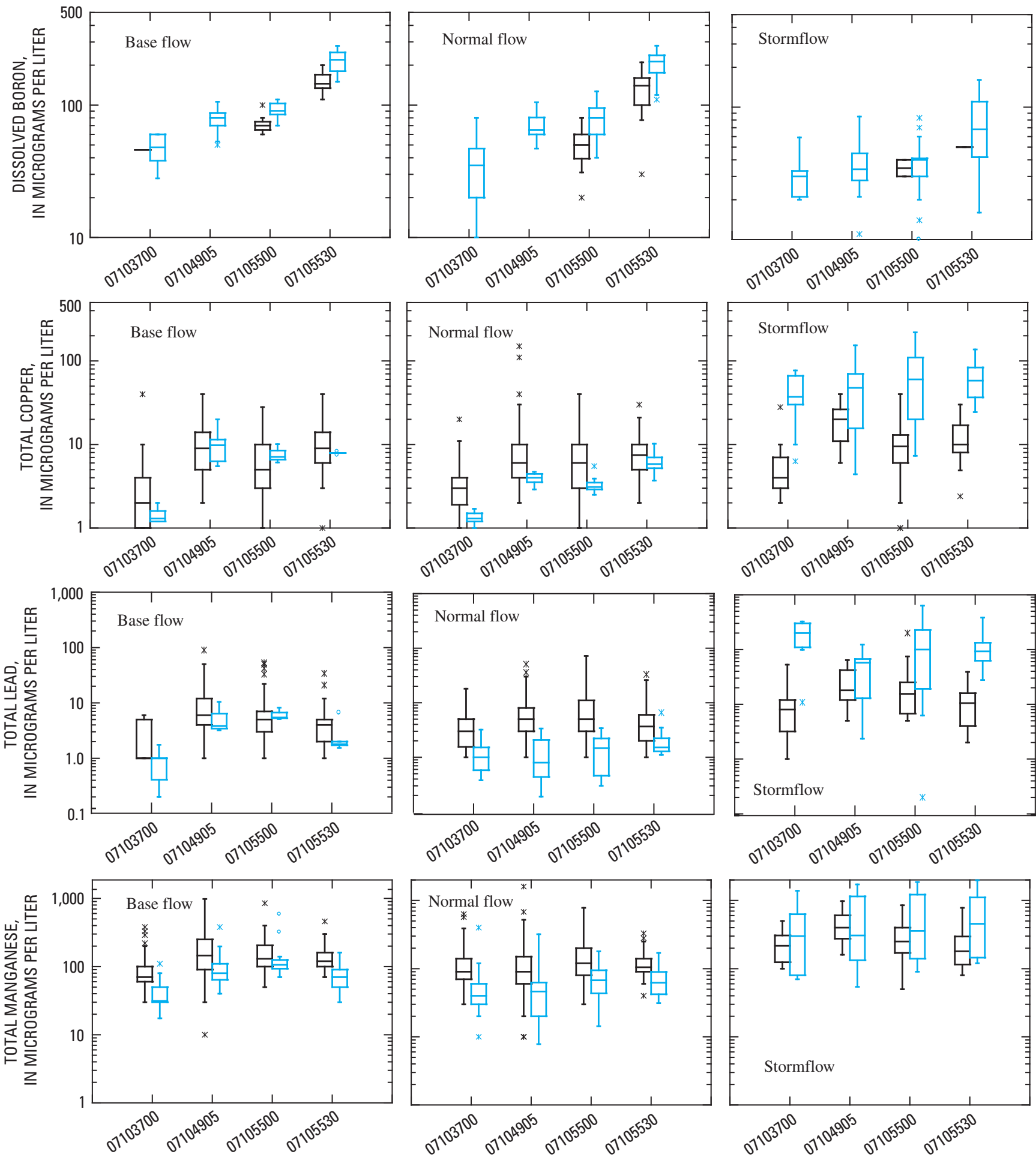

Figure 14. Variations in boron, copper, lead, and manganese concentrations between 1981 through 1997 and 1998 through 2006 at selected sites for base flow, normal flow, and stormflow in the Fountain and Monument Creek watersheds.

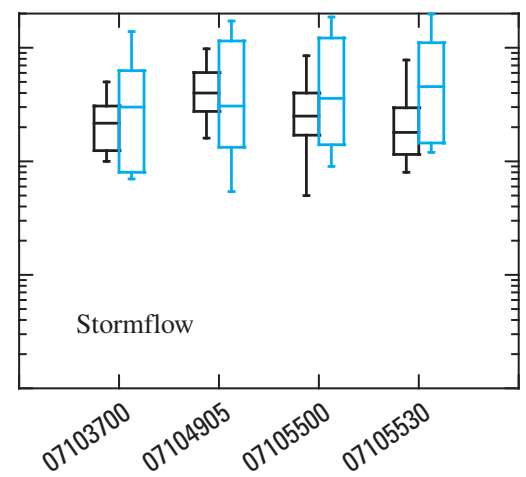

EXPLANATION

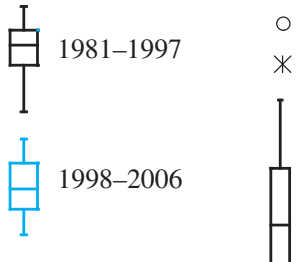

Outlier value

Outside value

Largest value within 1.5 times the IQR

Median $]$ Interquartile Range (IQR) 25th percentile

Smallest value within

1.5 times the IQR 

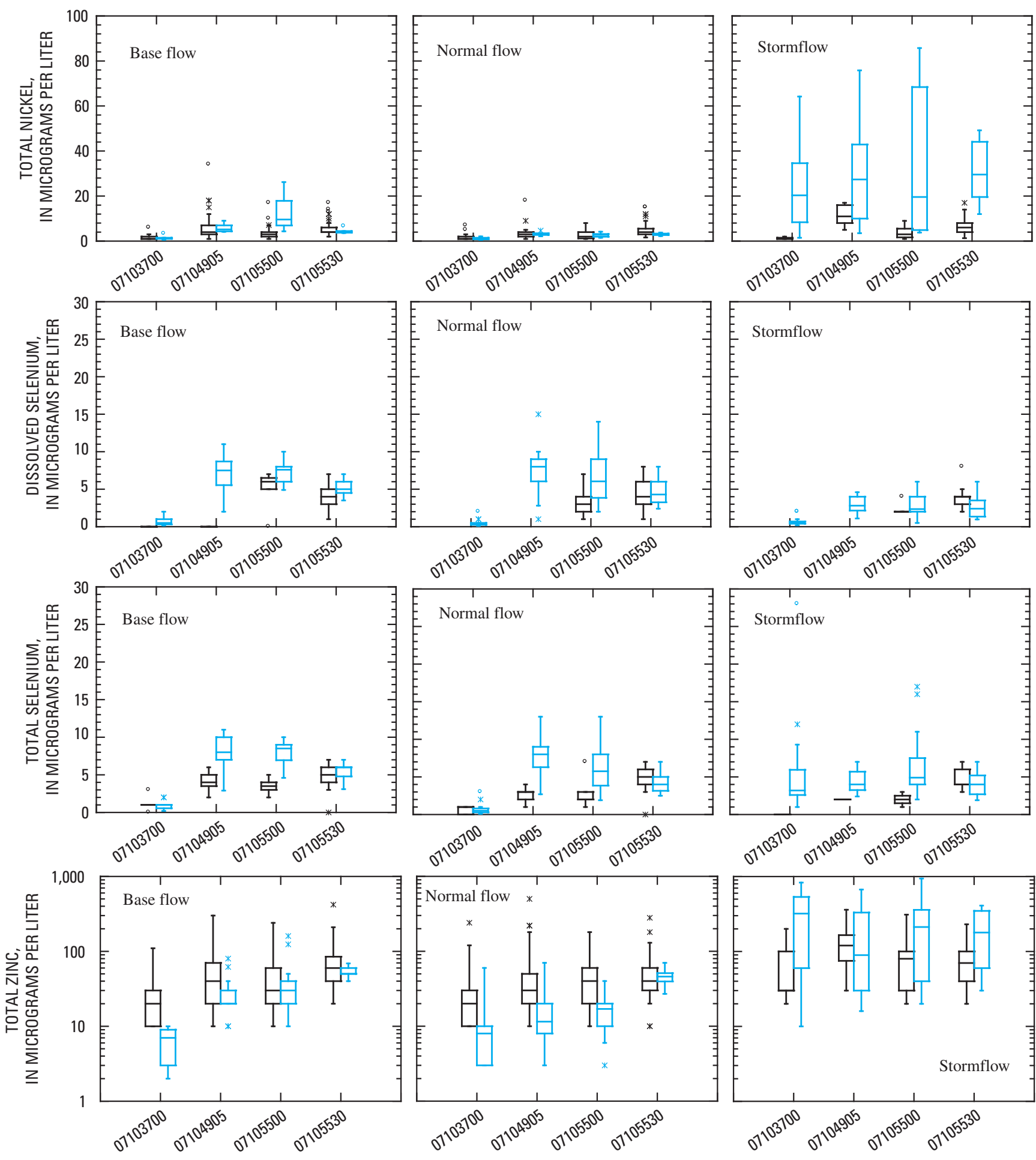

MAIN-STEM SITE
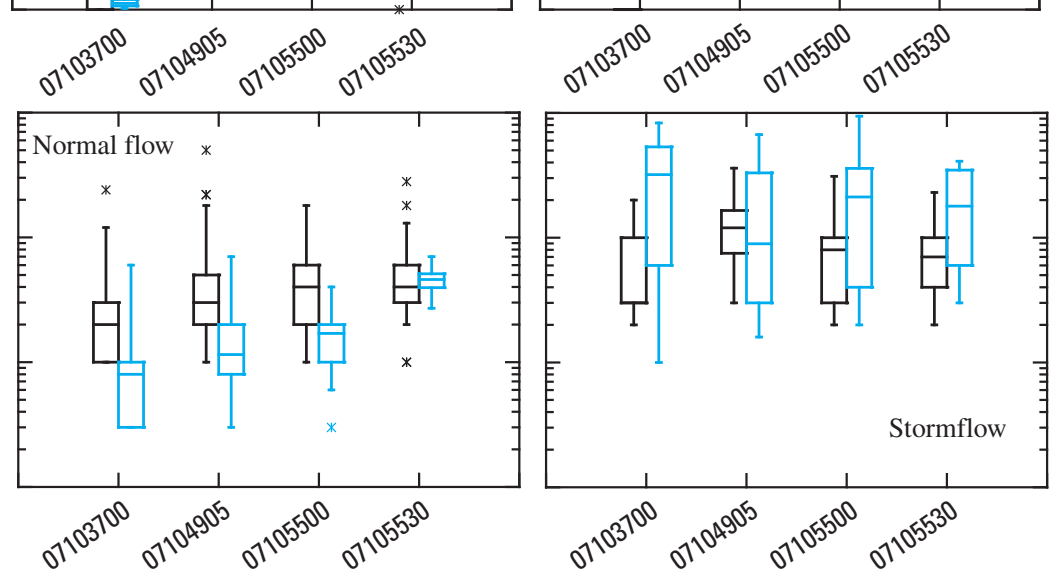

MAIN-STEM SITE

MAIN-STEM SITE

EXPLANATION

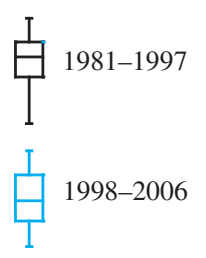

Figure 15. Variations in nickel, selenium, and zinc concentrations between 1981 through 1997 and 1998 through 2006 at selected main-stem sites for base flow, normal flow, and stormflow in the Fountain and Monument Creek watersheds.

- Outlier value * Outside value

\begin{tabular}{|c|c|}
\hline \multicolumn{2}{|c|}{ Largest value within } \\
\hline 75th percentile $\neg$ & \\
\hline Median & Interquartile Range (IQR) \\
\hline 25th percentile - & \\
\hline $\begin{array}{l}\text { Smallest value with } \\
1.5 \text { times the IQR }\end{array}$ & \\
\hline
\end{tabular}



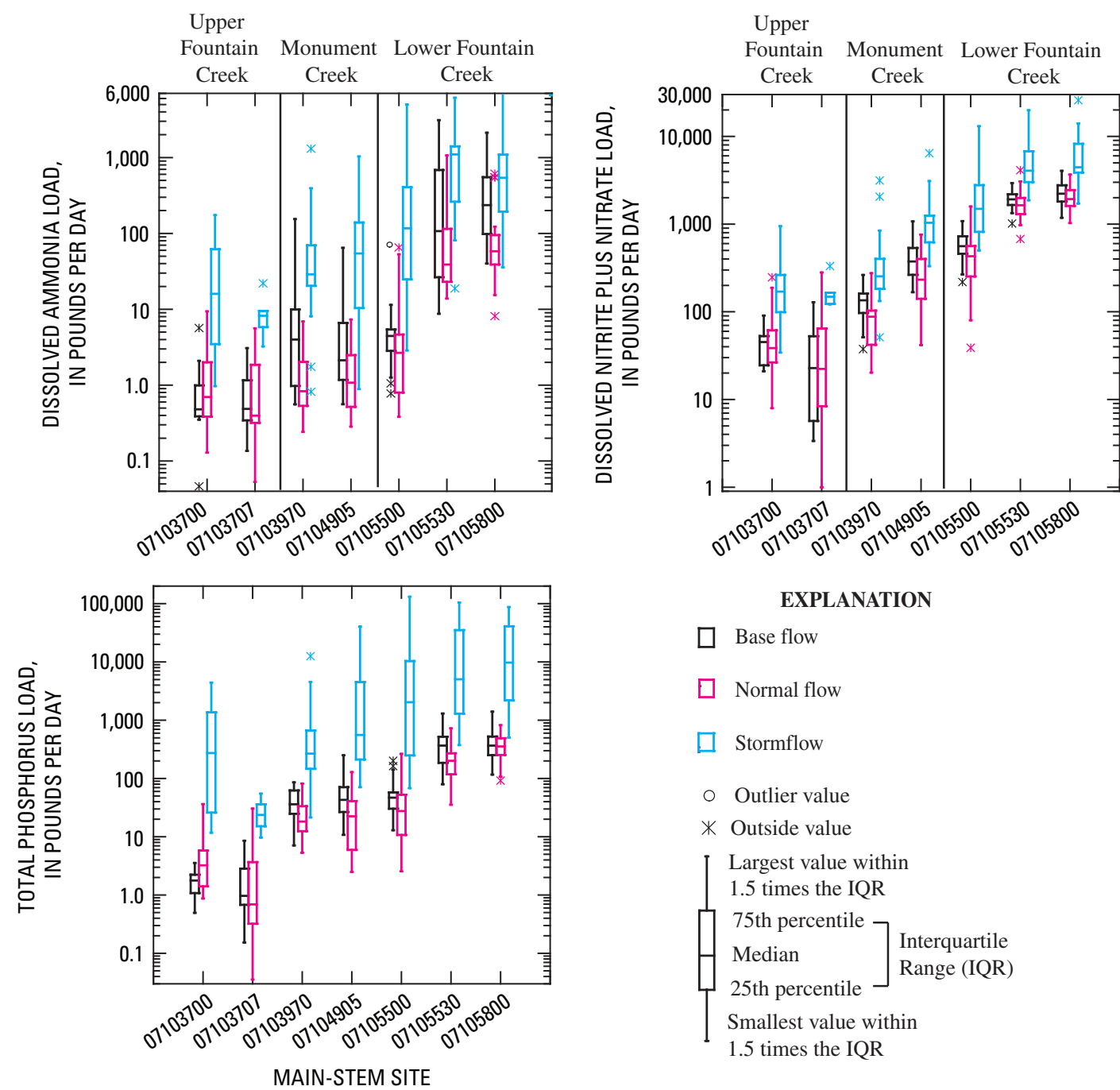

EXPLANATION

Base flow

Normal flow

Stormflow

○ Outlier value

* Outside value

Largest value within

1.5 times the IQR

$\left[\begin{array}{l}\text { 75th percentile } \\ \text { Median }\end{array}\right] \begin{aligned} & \text { Interquartile } \\ & \text { Range (IQR) }\end{aligned}$

Smallest value within

1.5 times the IQR

Figure 16. Variations in nitrogen and phosphorus loads at main-stem sites for base flow, normal flow, and stormflow in the Fountain and Monument Creek watersheds, 1998 through 2006.

estimated at site 07103970 (MoCr_Woodmen), depending on the selected nutrient. The median streamflow contribution during stormflow from sites 07103960 (lower_KeCr) and $385750104475001(\mathrm{PiCr})$ represented about 30 percent of the total median flow to site 07103970 (MoCr_Woodmen). Similarly, storm-load contributions of dissolved ammonia and total phosphorus at site 07103990 (lower_CoCr) represented 42 and 46 percent, respectively, of the total median loading estimated for these nutrients at site 07104905 (MoCr_Bijou).

Median streamflow during stormflow at Sand Creek site $07105600(\mathrm{SaCr})$ was about $250 \mathrm{ft}^{3} / \mathrm{s}$ and ranged from
5 to $1,000 \mathrm{ft}^{3} / \mathrm{s}$; therefore, the potential nutrient loading to downstream Fountain Creek site 07105800 (FoCr_Security) could have been substantial. Nutrient loads were larger at site 07105800 (FoCr_Security) than at any other main-stem site for all flow regimes except for dissolved ammonia, which decreased by 50 percent during stormflow between sites 07105530 (FoCr_Janitell) and 07105800 (FoCr_Security) (fig. 16). The nutrient load increase at site 07105800

(FoCr_Security) was not surprising because this site is the most downstream site in the study area and accumulates loads from throughout the watershed. 

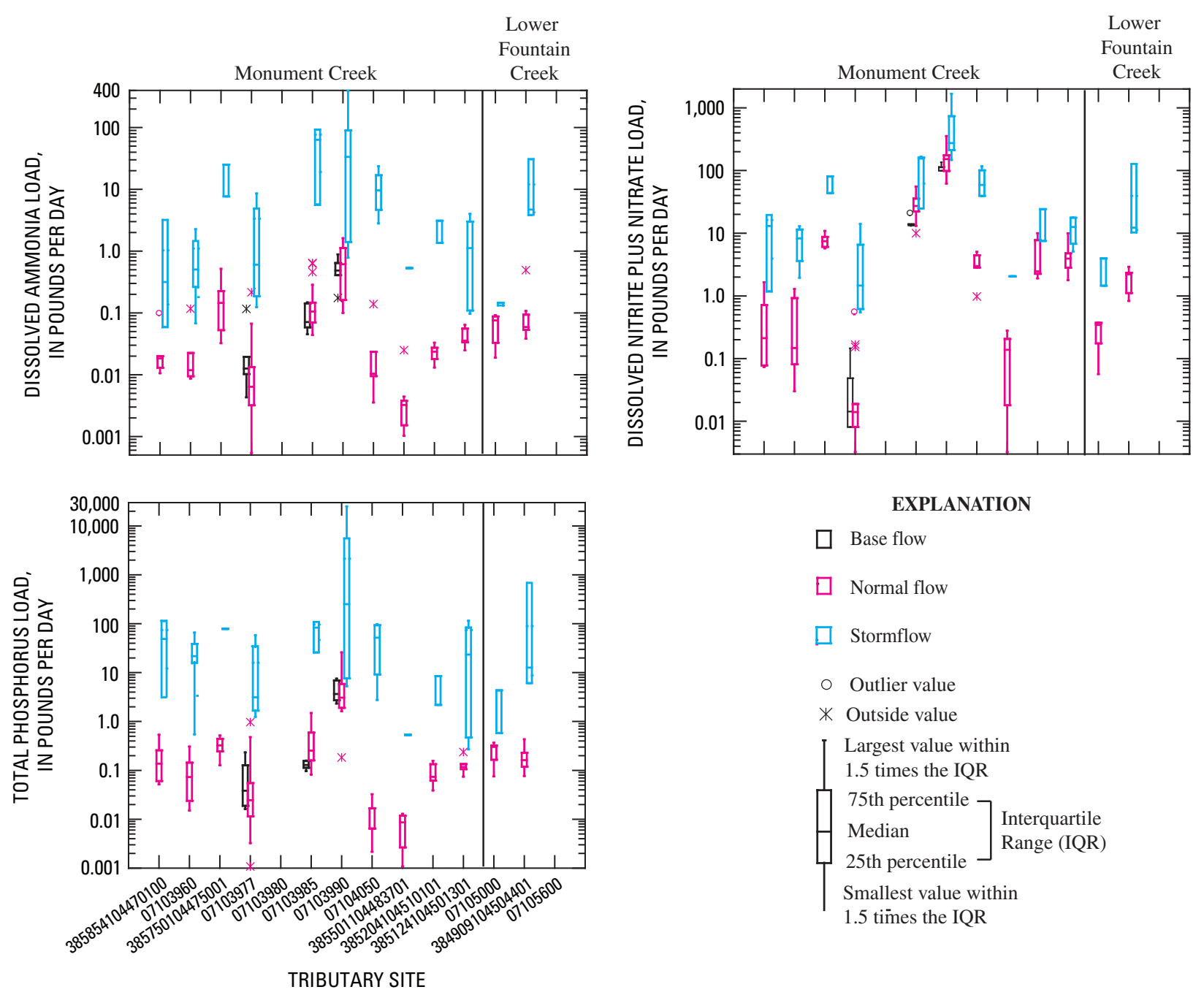

Figure 17. Variations in nitrogen and phosphorus loads at tributary sites for base flow, normal flow, and stormflow in the Fountain and Monument Creek watersheds, 1998 through 2006. 


\section{Trace-Element Loads}

\section{Trace-Element Loads in Upper Fountain Creek}

Instantaneous loads for the period 1998 through 2006 were calculated for dissolved boron, copper, selenium, and zinc and total arsenic, copper, lead, manganese, nickel, selenium, and zinc (figs. 18 and 19). Trace-element loads during base flow and normal flow generally were relatively small in Fountain Creek at sites 07103700 (FoCr_Manitou) and 07103707 (FoCr_8th), upstream from the confluence with Monument Creek. During base flow and normal flow, median loads were less than $5 \mathrm{lb} / \mathrm{d}$ for dissolved trace elements compared to stormflow loads that ranged from 4 to 12 times larger. The differences in loads are largely due to the proportional streamflow increase during periods of stormflow. Median base-flow and normal-flow loads of total arsenic, copper, lead, nickel, and selenium were less than $1 \mathrm{lb} / \mathrm{d}$ at sites 07103700 (FoCr_Manitou) and 07103707 (FoCr_8th), and stormflow loads for these constituents were 6 to more than 1,400 times larger than base-flow and normal-flow loads. Median total manganese and zinc loads at site 07103707 (FoCr_8th) were about 2 to 4 times larger than at site 07103700 (FoCr_Manitou) during base flow and normal flow, but loads at both sites generally were less than $6 \mathrm{lb} / \mathrm{d}$ for each constituent. Median stormflow loads at site 07103700 (FoCr_Manitou) for total manganese and zinc were 362 and $60 \mathrm{lb} / \mathrm{d}$, respectively, and were 112 to 319 times larger during stormflow than during base flow and normal flow.

\section{Trace-Element Loads in Monument Creek Upstream from Confluence}

Instantaneous loads were calculated for Monument Creek sites 07103970 (MoCr_Woodmen) and 07104905 (MoCr_Bijou). Base-flow and normal-flow loads for most dissolved constituents were less than $1 \mathrm{lb} / \mathrm{d}$ but were 2 to 8 times larger during stormflow. Median dissolved boron loads at site 07103970 (MoCr_Woodmen) ranged from 4.5 to $6.6 \mathrm{lb} / \mathrm{d}$ during base-flow and normal-flow periods and were about 2 times larger during stormflow. Loads of total trace elements also increased between base flow, normal flow, and stormflow, and at site 07104905 (MoCr_Bijou), depending on the constituent, were 3 to 1,440 times larger during storm periods. At this site, the median storm load of total lead was $72 \mathrm{lb} / \mathrm{d}$ compared to $0.05 \mathrm{lb} / \mathrm{d}$ or less during base-flow and normal-flow periods.

Loads of most dissolved and total trace elements increased between sites 07103970 (MoCr_Woodmen) and 07104905 (MoCr_Bijou) during base flow, normal flow, and stormflow (fig. 18). The load increase generally was between 2 and 4 times larger at the downstream site 07104905 (MoCr_Bijou) during base flow and normal flow but was larger during stormflow when loads at site 07104905 (MoCr_Bijou) increased by 1.2 to 18 times over loads at site 07103970 (MoCr_Woodmen). Trace-element loads were not estimated for Monument Creek tributaries because concentration data were not collected during 1998 through 2006, but load contributions from tributaries could be considerable during stormflow and could account for some of the loads estimated at site 07104905 (MoCr_Bijou).

\section{Trace-Element Loads in Fountain Creek Downstream from Confluence}

Loads for most dissolved and total trace elements increased at Fountain Creek sites downstream from the confluence with Monument Creek (fig. 18). The increase corresponded to the increase in streamflow measured at sites 07105500 (FoCr_Nevada), 07105530 (FoCr_Janitell), and 07105800 (FoCr_Security). The median base flow and normal flow at site 07105530 (FoCr_Janitell) were 2 to 3 times larger than at site 07105500 (FoCr_Nevada), and the differences in streamflow between the two sites can be attributed to the Las Vegas Street Wastewater Treatment Plant. The difference, however, in selected trace-element loads was much larger than the differences in streamflow between the two sites. During normal-flow conditions, the median loads of dissolved boron, total copper, and total zinc were about 9 times larger at site 07105530 (FoCr_Janitell) than at site 07105500 (FoCr_Nevada). Median dissolved zinc loads during normal flow increased from 0.7 to $19.0 \mathrm{lb} / \mathrm{d}$ between the two sites, a 2,600-percent increase that cannot be attributed solely to the increased streamflow. Zinc commonly is found in urban runoff and is directly correlated with street traffic volumes (University of Wisconsin-Extension, 1997) and may be contributing to the increase. At site 07105800 (FoCr_Security), the most downstream site for purposes of this report, traceelement loads generally were similar to or slightly larger than at site 07105530 (FoCr_Janitell) during base flow and normal flow. Median storm loads were 2 to 565 times larger than baseflow and normal-flow loads; total lead and total manganese increased by factors of 412 and 72, respectively, compared to normal flow.

\section{Suspended Sediment}

Suspended-sediment discharge is the mass of suspended sediment transported over time and, in this report, is expressed in tons per day (tons/d). Sediment discharge in a stream is the result of erosion and sediment-transport rates that occur throughout the watershed. Tributaries may discharge large volumes of sediment to a stream, and others may discharge small volumes. Additionally, in-channel processes erode banks, mobilize (scour) bed sediments, and deposit (fill) bed sediments. Eroded sediments can be transported by two modes: by rolling, bouncing, and sliding along the bed as "bedload," or by being transported in the water column by turbulence as "suspended load." Total sediment load is the sum of bedload and suspended load. Von Guerard (1989b) indicated that in Fountain and Monument Creeks, bedload represented about 6 to 30 percent of the total sediment load 

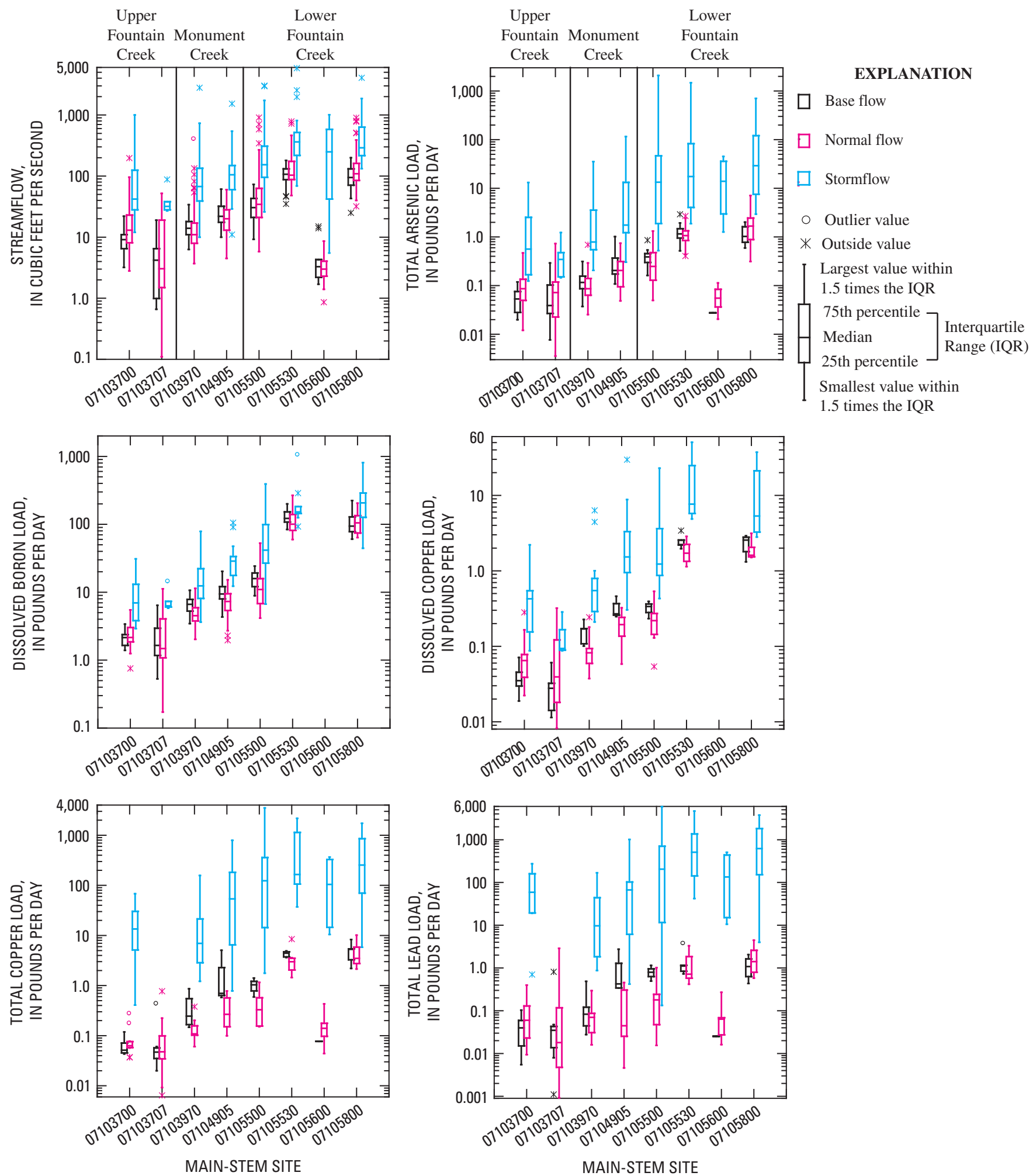

Figure 18. Variations in streamflow, arsenic, boron, copper, and lead loads at main-stem sites for base flow, normal flow, and stormflow in the Fountain and Monument Creek watersheds, 1998 through 2006. 

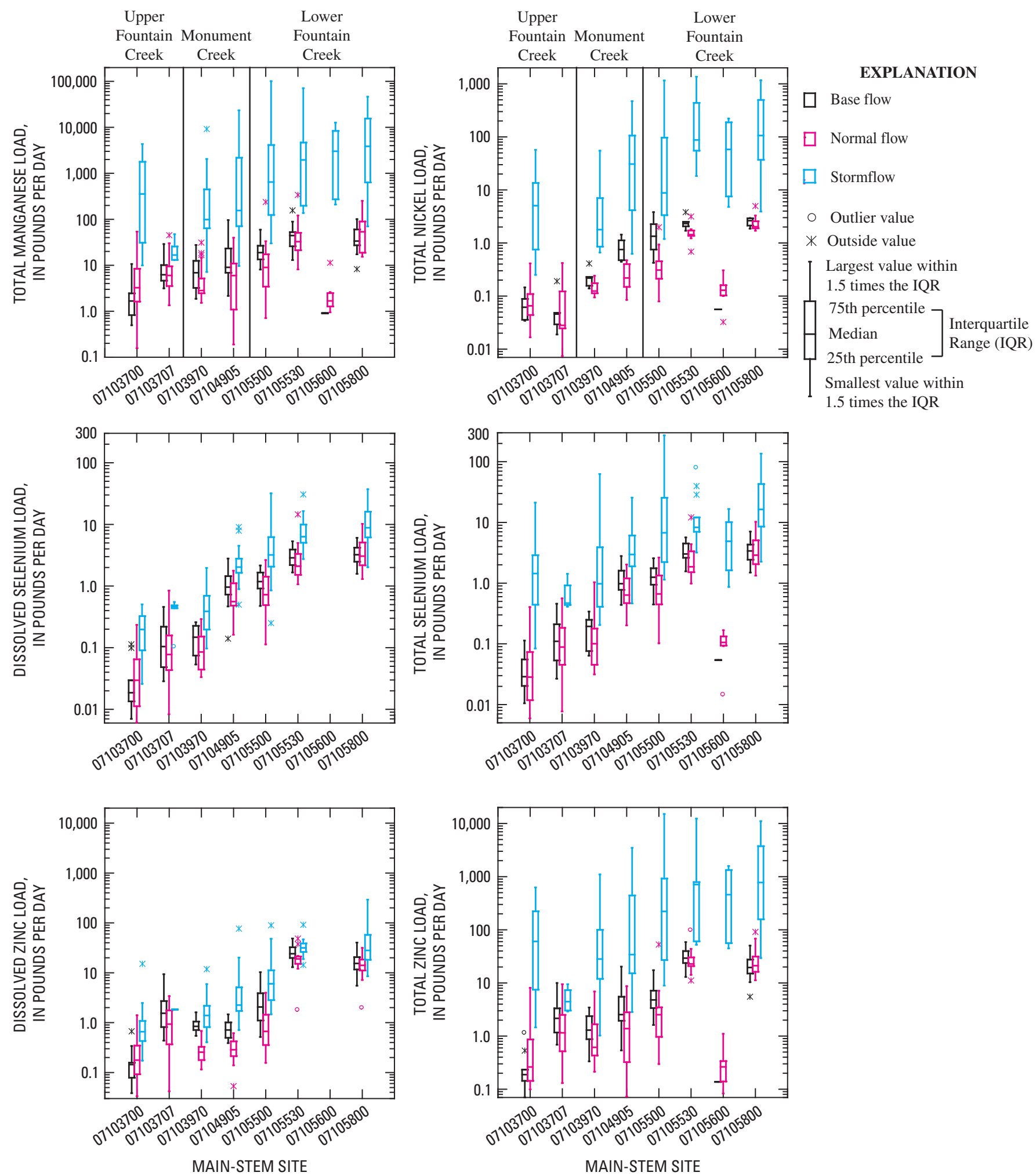

Figure 19. Variations in manganese, nickel, selenium, and zinc loads at main-stem sites for base flow, normal flow, and stormflow in the Fountain and Monument Creek watersheds, 1998 through 2006. 
during stormflow. This report discusses results of suspended-sediment sampling from 1998 through 2005. Daily suspended-sediment yield was computed by dividing the daily suspended-sediment discharge by the drainage area and, in this report, is expressed in tons per day per square mile (tons $/ \mathrm{d} / \mathrm{mi}^{2}$ ). Von Guerard (1989a) indicated that the areas producing the largest suspended-sediment yields tended to be in streams on the readily erodible Colorado Piedmont. Between 1998 and 2001, daily suspended-sediment concentrations were measured, and suspended-sediment discharges were computed from April through September at six sites (table 1). Three sites in the Cottonwood Creek watershed and one site on Fountain Creek were discontinued after 2002: sites 07103977 (upper_CoCr), 07103980 (middle_CoCr), 07103985 (TbCo), and 07103700 (FoCr_Manitou). Daily suspended-sediment concentrations were measured and discharges were computed at two additional sites: 07104905 (MoCr_Bijou) on Monument Creek and 07105600 (SaCr) on Sand Creek, from 2003 to 2006. Suspended-sediment concentration data were collected from April 1 through September 30 during 2003 through 2006 because those months generally encompass the period that usually has appreciable stormflow. Data for all sites are published in Crowfoot and others (water years 1998-2005).

The base-flow separation program described earlier was used to identify daily suspended-sediment data as being associated either as base flow, normal flow, or as stormflow. These data were used to characterize suspended-sediment concentrations, suspended-sediment discharges, and suspended-sediment yields for base-flow, normal-flow, and stormflow conditions, which were then used to evaluate annual variations in suspended-sediment concentrations, suspendedsediment discharges, and suspended-sediment yields for base-flow, normal-flow, and stormflow conditions. Spatial variations in suspended-sediment concentrations, suspendedsediment discharges, and suspended-sediment yields also were evaluated.

A Mann-Whitney test of suspended-sediment concentrations, suspended-sediment discharges, and suspendedsediment yields evaluated statistical differences between adjacent sites during base flow, normal flow, and stormflow. Differences between tributaries during base flow, normal flow, and stormflow also were evaluated.

An evaluation of annual variations in suspendedsediment concentrations, suspended-sediment discharges, and suspended-sediment yields for base-flow, normal-flow, and stormflow conditions indicated that annual variations in suspended-sediment concentrations, suspended-sediment discharges, and suspended-sediment yields coincided with variations in the number of stormflow days. Suspendedsediment concentrations, discharges, and yields at sites in the Fountain Creek watershed were larger during wet years than during dry years. If the number of stormflow days during a year was greater than the average number of stormflow days per year plus one-half standard deviation, then the year was wet. If the number of stormflow days during a year was less than the average number of stormflow days per year minus one-half standard deviation, the year was considered dry.

\section{Spatial Variations in Suspended-Sediment Concentrations}

\section{Base Flow}

Spatial variations in suspended-sediment concentrations were observed between sites in the Monument Creek watershed during base flow (fig. 20A). Suspendedsediment concentrations increased between sites 07103970 (MoCr_Woodmen) and 07104905 (MoCr_Bijou). The increase in suspended-sediment concentrations between site 07103970 (MoCr_Woodmen) and site 07104905 (MoCr_Bijou) is likely the result of contributions of suspended sediment from intervening tributaries such as Cottonwood Creek, site 07103990 (lower_CoCr). Median suspended-sediment concentrations at site 07103990 (lower_CoCr) were significantly larger than median suspended-sediment concentrations at site 07103970 (MoCr_Woodmen) and site 07104905 (MoCr_Bijou) (table 5). Spatial variations in suspended-sediment concentrations between sites 07104905 (MoCr_Bijou) and 07105500 (FoCr_Nevada) and sites 07105500 (FoCr_Nevada) and 07105800 (FoCr_Security) showed no significant differences during base flow (fig. 20A, table 5).

\section{Normal Flow}

Spatial variations of suspended-sediment concentrations in the Fountain and Monument Creek watersheds indicated that during normal flow, site 07103970 (MoCr_Woodmen) had the smallest suspended-sediment concentrations and site 07103990 (lower_CoCr) had the largest suspendedsediment concentrations (fig. 20A). Median suspendedsediment concentrations during normal flow tended to increase in a downstream direction and varied significantly between most sites (fig. 20A, table 5). Median suspendedsediment concentrations decreased significantly between sites 07103990 (lower_CoCr) and 07104905 (MoCr_Bijou), and sites 07105600 ( $\mathrm{SaCr}$ ) and 07105800 (FoCr_Security) did not have significantly different median concentrations (fig. 20A, table 5) from one another. Site 07103990 (lower_CoCr) had significantly larger median suspended-sediment concentrations than site $07105600(\mathrm{SaCr})$.

\section{Stormflow}

Spatial differences in suspended-sediment concentrations were observed between most sites in the Fountain and Monument Creek watersheds during stormflow (fig. 20A). On Monument Creek, suspended-sediment concentrations tended to increase in a downstream direction. Site 07103990 (lower_CoCr) had the largest concentrations. Spatial variations 


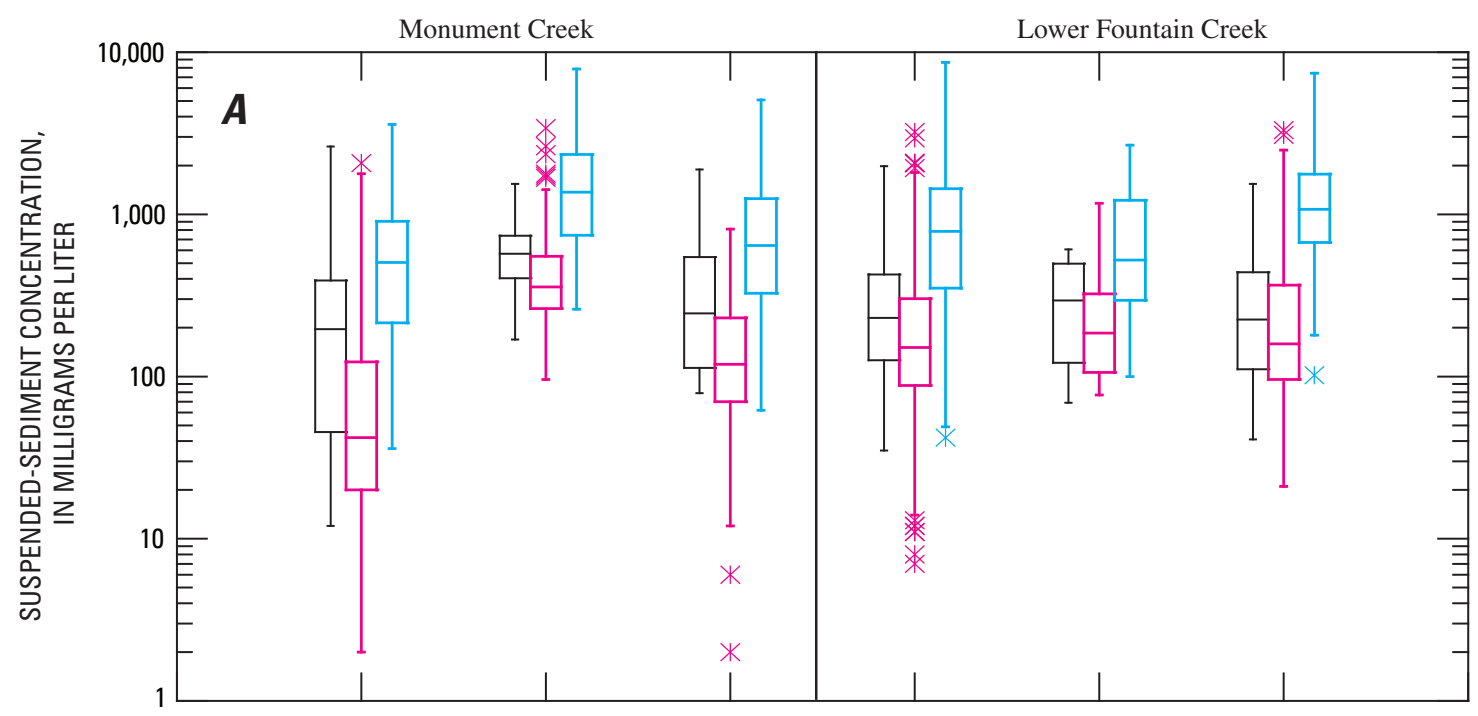

\section{EXPLANATION}
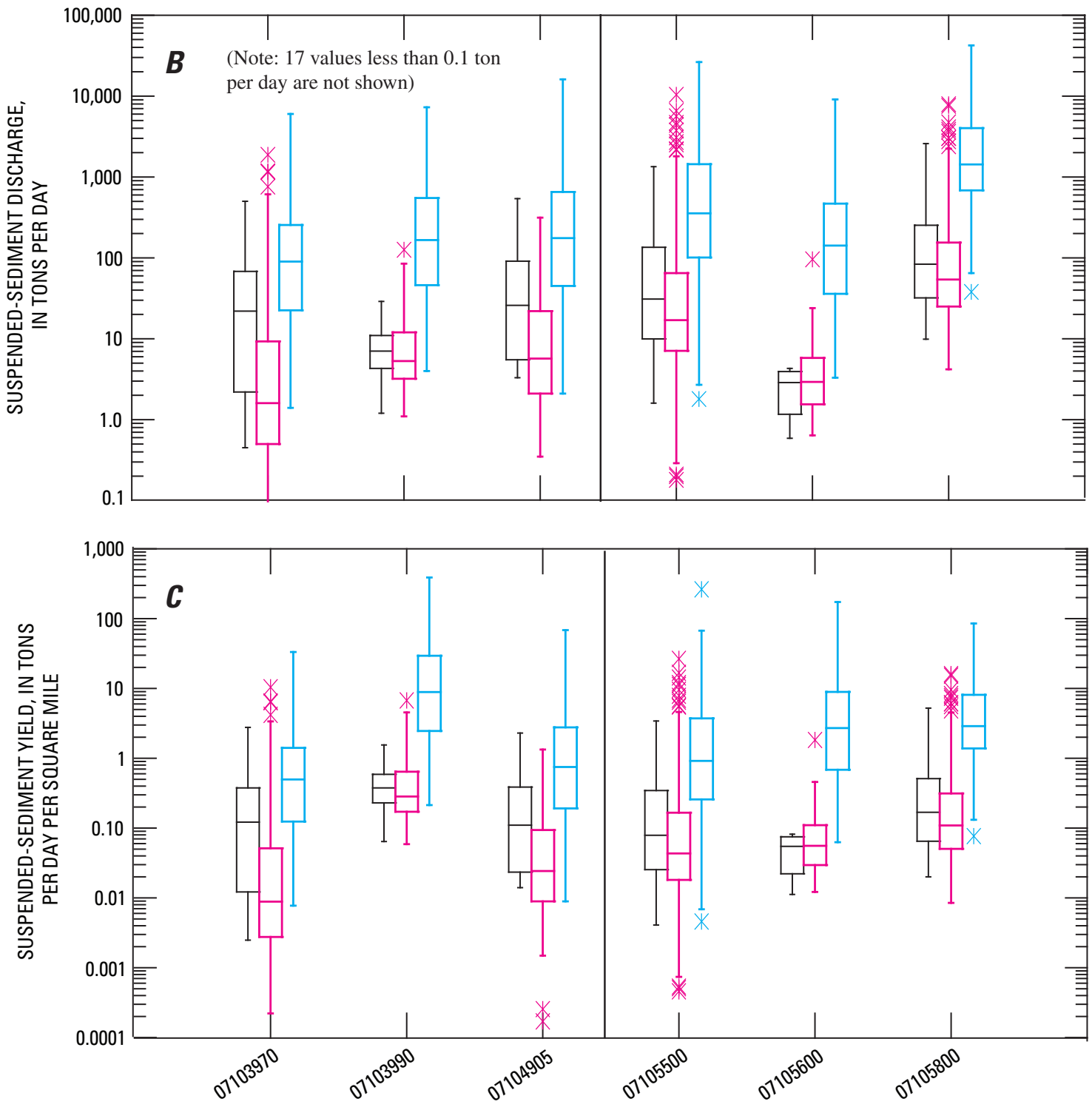

SITE

Figure 20. Variations in $(A)$ suspended-sediment concentration, $(B)$ suspended-sediment discharge, and $(C)$ suspended-sediment yield for base flow, normal flow, and stormflow at selected main-stem and tributary sites in Fountain and Monument Creek watersheds, 1998 through 2005. 


\section{Stormflows and Wastewater Treatment-Plant Effluent Discharges, Colorado Springs, Colorado, 1981-2006}

Table 5. Median suspended-sediment concentration during base flow, normal flow, and stormflow in the Fountain and Monument Creek watersheds, and p-values of Mann-Whitney test of significance of spatial variations in suspended-sediment concentrations.

[Shaded cells indicate test is significant]

\begin{tabular}{|c|c|c|c|c|c|c|c|}
\hline \multirow[b]{2}{*}{ Site number } & \multirow{2}{*}{$\begin{array}{l}\text { Median suspended- } \\
\text { sediment } \\
\text { concentration, } \\
\text { in milligrams per liter }\end{array}$} & \multirow{2}{*}{$\begin{array}{c}\text { Median } \\
\text { rank }\end{array}$} & \multicolumn{5}{|c|}{ Mann-Whitney test p-values of significance of spatial variation between sites } \\
\hline & & & 07103990 & 07104905 & 07105500 & 07105600 & 07105800 \\
\hline \multicolumn{8}{|c|}{ Base flow } \\
\hline 07103970 & 196 & 1 & 0 & 0.0284 & & & \\
\hline 07103990 & 571 & 6 & & .0001 & & 0.0792 & \\
\hline 07104905 & 245 & 4 & & & 0.7562 & & \\
\hline 07105500 & 230 & 3 & & & & & 0.4781 \\
\hline 07105600 & 310 & 5 & & & & & .7640 \\
\hline 07105800 & 225 & 2 & & & & & \\
\hline \multicolumn{8}{|c|}{ Normal flow } \\
\hline 07103970 & 42.0 & 1 & 0 & 0 & & & \\
\hline 07103990 & 357 & 6 & & 0 & & 0 & \\
\hline 07104905 & 119 & 2 & & & 0.0023 & & \\
\hline 07105500 & 151 & 3 & & & & & 0.0198 \\
\hline 07105600 & 186 & 5 & & & & & .6845 \\
\hline 07105800 & 159 & 4 & & & & & \\
\hline \multicolumn{8}{|c|}{ Stormflow } \\
\hline 07103970 & 505 & 1 & 0 & 0.0040 & & & \\
\hline 07103990 & 1,370 & 6 & & 0 & & 0 & \\
\hline 07104905 & 642 & 3 & & & 0.2345 & & \\
\hline 07105500 & 786 & 4 & & & & & 0.0001 \\
\hline 07105600 & 523 & 2 & & & & & .0001 \\
\hline 07105800 & 1,080 & 5 & & & & & \\
\hline
\end{tabular}


in median suspended-sediment concentrations between sites 07104905 (MoCr_Bijou) and 07105500 (FoCr_Nevada) showed no significant differences during stormflow (table 5). Suspended-sediment concentrations in lower Fountain Creek between sites 07105500 (FoCr_Nevada) and 07105800 (FoCr_Security) showed a significant increase (table 5), indicating a substantial source of suspended sediments exists between these two sites. Suspended-sediment concentrations in Sand Creek, site 07105600 ( $\mathrm{SaCr}$ ), were significantly less than concentrations at site 07105800 (FoCr_Security) during stormflow. USGS personnel believe the Sand Creek watershed to be a major source area of suspended sediment to Fountain Creek and partly explains significant increases in stormflow suspended-sediment concentrations between sites 07105500 (FoCr_Nevada) and 07105800 (FoCr_Security). An evaluation of differences between suspended-sediment concentrations of Cottonwood Creek and Sand Creek indicated that Cottonwood Creek tended to have larger suspendedsediment concentrations. Concentrations at site 07103970 (MoCr_Woodmen) during stormflow generally were between about 200 and about 1,000 mg/L. Suspended-sediment concentrations at site 07103990 (lower_CoCr) generally ranged from 750 to $2,300 \mathrm{mg} / \mathrm{L}$. At the two sites on Fountain Creek downstream from the confluence with Monument Creek (sites 07105500 [FoCr_Nevada] and 07105800 [FoCr_Security]), suspended-sediment concentrations generally ranged between about $500 \mathrm{mg} / \mathrm{L}$ and 1,700 mg/L during stormflow. The largest suspended-sediment concentrations during stormflow were measured on Cottonwood Creek.

\section{Spatial Variations in Suspended-Sediment Discharges}

\section{Base Flow}

Spatial variations in suspended-sediment discharges were observed between sites 07103970 (MoCr_Woodmen) and 07103990 (lower_CoCr) and between sites 07103990 (lower_CoCr) and 07104905 (MoCr_Bijou) in the Monument Creek watershed during base flow (fig. 20B). Suspended-sediment discharges between sites 07103970 (MoCr_Woodmen) and 07104905 (MoCr_Bijou) showed no significant differences during base flow (fig. 20, table 6). Median suspended-sediment discharges at site 07103990 (lower_CoCr) were significantly larger than median suspended-sediment discharges at site 07103970 (MoCr_Woodmen) and site 07104905 (MoCr_Bijou) (table 6). The lack of significant change in suspended-sediment discharges between sites 07103970 (MoCr_Woodmen) and 07104905 (MoCr_Bijou) during base flow indicate that tributary inputs of suspended sediment are insignificant and (or) tributary inputs are being offset by in-channel storage along the reach. Spatial variations in suspended-sediment discharges between sites 07104905 (MoCr_Bijou) and
07105500 (FoCr_Nevada) showed no significant differences during base flow (fig. 20B, table 6). Suspended-sediment discharges increased significantly between sites 07105500 (FoCr_Nevada) and 07105800 (FoCr_Security) and between sites 07105600 (SaCr) and 07105800 (FoCr_Security) during base flow.

\section{Normal Flow}

Spatial differences in suspended-sediment discharge were observed between most sites in the Fountain Creek watershed during normal flow (fig. 20B). Median suspended-sediment discharges were significantly $(\mathrm{p}<0.05)$ different between several sites. Sites ranked from smallest to largest median suspended-sediment discharges during normal flow (table 6) were 07103970 (MoCr_Woodmen), 07105600 (SaCr), 07103990 (lower_CoCr), 07104905 (MoCr_Bijou), 07105500 (FoCr_Nevada), and 07105800 (FoCr_Security). Suspendedsediment discharge increased in a downstream direction as streamflow increased for the Fountain and Monument Creek sites (fig. 20B). All sites, except 07103990 (lower_CoCr) and 07104905 (MoCr_Bijou), were significantly different from one another (table 6).

During normal flow, site 07103990 (lower_CoCr), a site with the smallest drainage area $\left(18.7 \mathrm{mi}^{2}\right)$ and second smallest streamflow, had suspended-sediment discharges comparable or larger than sites with drainage areas 3 to 10 times larger. Suspended-sediment discharges at site 07103990 (lower_CoCr) generally ranged from 3 to 10 tons/d (fig. 20B). Suspended-sediment discharges at site 07103970

(MoCr_Woodmen), with a drainage area of $180 \mathrm{mi}^{2}$ and located 0.5 mi upstream from Cottonwood Creek, generally ranged from 0.5 to 10 tons/d. Suspended-sediment discharges at site 07104905 (MoCr_Bijou), with drainage area of $228 \mathrm{mi}^{2}$ and located $0.7 \mathrm{mi}$ upstream from the confluence with Fountain Creek, generally ranged from about 2 to more than 20 tons/d during normal flow. Suspended-sediment discharges at site 07105500 (FoCr_Nevada), drainage area $384 \mathrm{mi}^{2}$ and located $1.3 \mathrm{mi}$ downstream from the confluence with Monument Creek, generally ranged from 7 to 80 tons/d during normal flow. Suspended-sediment discharges at site $07105600(\mathrm{SaCr})$, with a drainage area of $52.6 \mathrm{mi}^{2}$ and upstream from site 07105800 (FoCr_Security), generally ranged from about 1.5 to 6 tons/d during normal flow. The largest suspended-sediment discharges during normal flow occurred at site 07105800 (FoCr_Security), which had the largest drainage area (499 $\mathrm{mi}^{2}$ ) and largest streamflows; suspended-sediment discharge usually was larger than about 80 tons/d and generally ranged from about 25 to 180 tons/ d. A Mann-Whitney test indicated significant differences in median suspended-sediment discharges between most sites. Differences in median suspended-sediment discharges between sites 07103990 (lower_CoCr) and 07104905 (MoCr_Bijou) were not significant, indicating that sediment discharge from Cottonwood Creek may represent a significant fraction of sediment discharge at site 07104905 (MoCr_Bijou) 
Table 6. Median suspended-sediment discharge during base flow, normal flow, and stormflow in the Fountain and Monument Creek watersheds, and p-values of Mann-Whitney test of significance of spatial variations in suspended-sediment discharge.

[Shaded cells indicate test is significant]

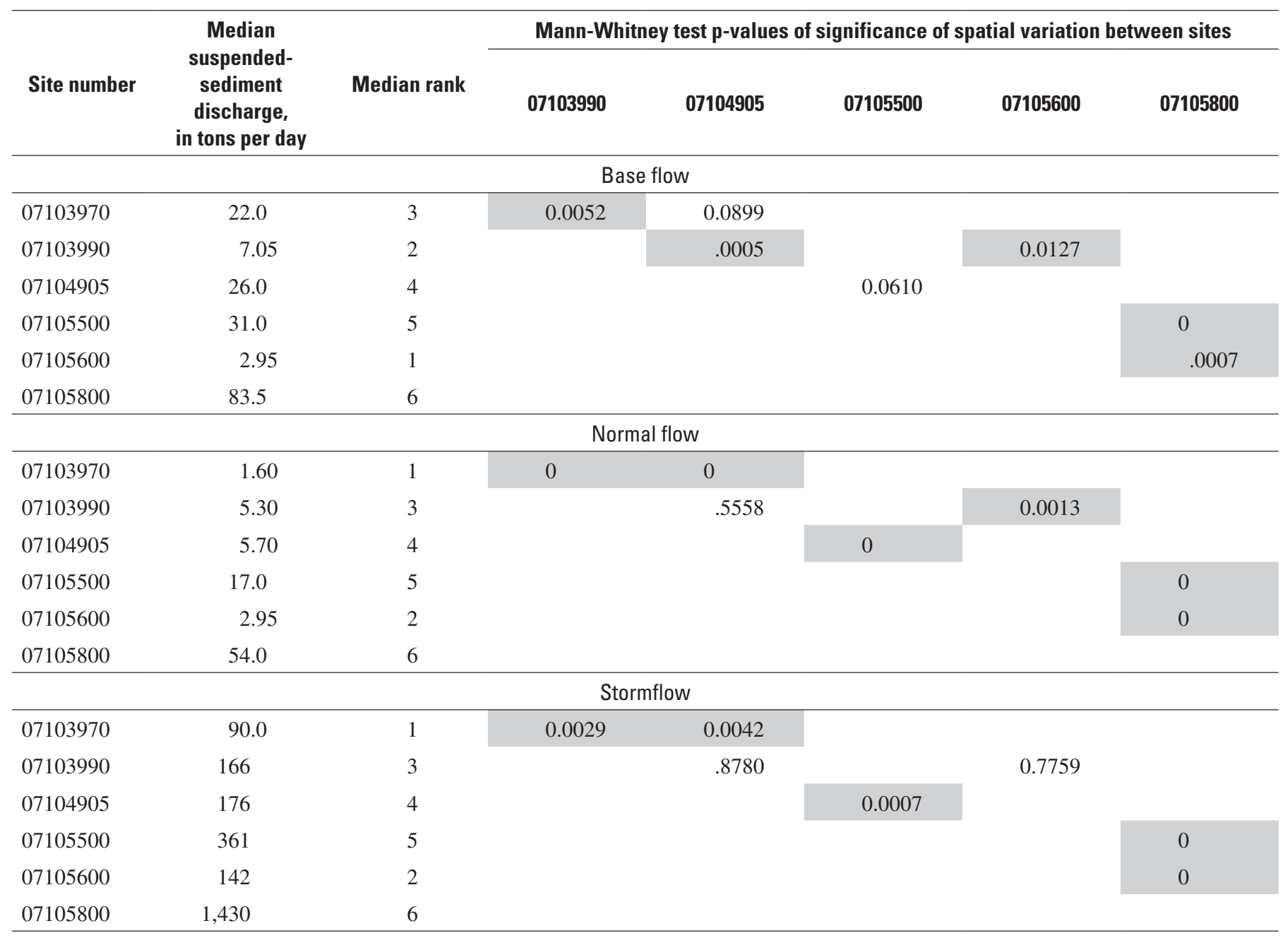


during normal flow. However, in-channel storage of suspended sediment from Cottonwood Creek and contributions of suspended sediment from other tributaries and in-channel sources along the intervening reach also can explain the similarities in suspended-sediment discharge between sites 07103990 (lower_CoCr) and 07104905 (MoCr_Woodmen). Median suspended-sediment discharges at 07103990 (lower_CoCr) were almost 2 times larger than median suspended-sediment discharges at site $07105600(\mathrm{SaCr})$.

\section{Stormflow}

During stormflow, site 07103970 (MoCr_Woodmen) generally had the smallest suspended-sediment discharges that generally ranged from about 20 to 250 tons/d. Site 07103990 (lower_CoCr), the site with the smallest drainage area, had suspended-sediment discharges that generally ranged from 40 to about 500 tons/d. Although site 07103990 (lower_CoCr) has a drainage area of about $18.7 \mathrm{mi}^{2}$, almost 90 percent less drainage area than site 07103970 (MoCr_Woodmen), the median suspended-sediment discharge was almost 2 times larger than the median sediment discharge at site 07103970. Site 07105800 (FoCr_Security) had the largest suspendedsediment discharges that generally ranged from about 700 to 4,000 tons/d during stormflow. Suspended-sediment discharges at site 07104905 (MoCr_Bijou) generally ranged from about 40 to 600 tons/d. Suspended-sediment discharges at site 07105500 (FoCr_Nevada), located a few miles upstream from site 07105800 (FoCr_Security) and about 1.3 mi downstream from the confluence with Monument Creek, generally ranged from about 100 to 1,500 tons/d during stormflow. Suspended-sediment discharge at site 07105600 (SaCr) generally ranged from about 40 to 500 tons/d, confirming earlier studies (Edelmann and others, 2002; von Guerard, 1989a) in which Sand Creek was identified as a major source of sediment between sites 07105500 (FoCr_Nevada) and 07105800 (FoCr_Security) during stormflow.

\section{Cumulative Suspended-Sediment Discharge}

Variations in total cumulative daily suspended-sediment discharges from 1998 through 2001 and 2002 through 2005 are shown in figures 21 and 22 and table 7. The April through September cumulative suspended-sediment discharges and streamflows were largest in 1999 at all sites, a result of a large storm that continued for 6 consecutive days between April 29 and May 4, 1999 (Edelmann and others, 2002). Total cumulative daily suspended-sediment discharges increased from upstream to downstream sites. Suspendedsediment discharges at Cottonwood Creek, site 07103990 (lower_CoCr), generally were larger than suspended-sediment discharges from upper Monument Creek, site 07103970 (MoCr_Woodmen), in 5 of 8 years, despite the larger drainage area at site 07103970 . An evaluation of relative contribution of suspended-sediment discharge at site 07103990 (lower_CoCr) to downstream sites indicated that if suspended-sediment discharge from 07103990 (lower_CoCr) remained in suspension along the intervening reach, it represented 18 to 30 percent of the suspended-sediment discharge at site 07104905 (MoCr_Bijou) (table 7). Suspended-sediment discharge at site 07103970 (MoCr_Woodmen) can represent 13 to 18 percent of the suspended-sediment discharge at site 07104905 (MoCr_Bijou) (table 7). Cumulative suspendedsediment discharge at site 07103970 (MoCr_Woodmen) and 07103990 (lower_CoCr) only accounted for about 35 to 45 percent of suspended-sediment discharge at site 07104905 (MoCr_Bijou), indicating that additional sources of suspended-sediment discharge exist between sites 07103970 (MoCr_Woodmen) and 07103990 (lower_CoCr) and site 07104905 (MoCr_Bijou). Cumulative suspendedsediment discharge at site 07104905 (MoCr_Bijou) generally was similar to suspended-sediment discharge at site 07105500 (FoCr_Nevada), ranging from 60 to 98 percent (table 7). Cumulative suspended-sediment discharge at site 07105500 (FoCr_Nevada) generally represented about 70 percent of suspended-sediment discharge at site 07105800 (FoCr_Security). The addition of site 07105600 (SaCr) to the monitoring network in 2003 provided evidence that Sand Creek contributed substantially to suspended-sediment discharge in Fountain Creek during storm runoff. Relative contributions of suspended-sediment discharge from site 07105600 (SaCr) to site 07105800 (FoCr_Security) ranged from 23 to 37 percent. In-channel storage of suspended sediment from gaged sites, suspended-sediment contributions from ungaged tributaries, and mobilization of in-channel sediments along the intervening reaches would decrease the relative contributions of suspended-sediment discharge from upstream to downstream sites. Sediment-source tracking evaluations are necessary to accurately define relative contributions of sediment from one location to another.

\section{Spatial Variations in Suspended-Sediment Yields}

Suspended-sediment yields normalize suspendedsediment discharges by dividing the sediment discharges by the drainage area. Suspended-sediment yields provide a means for identifying source-contribution areas.

\section{Base Flow}

Spatial variations in suspended-sediment yields were observed between sites 07103970 (MoCr_Woodmen) and 07103990 (lower_CoCr) and between sites 07103990 (lower_CoCr) and 07104905 (MoCr_Bijou) in the Monument Creek watershed during base flow (fig. 20C). Suspendedsediment yields between sites 07103970 (MoCr_Woodmen) and 07104905 (MoCr_Bijou) showed no significant differences during base flow (fig. 20C, table 8). 

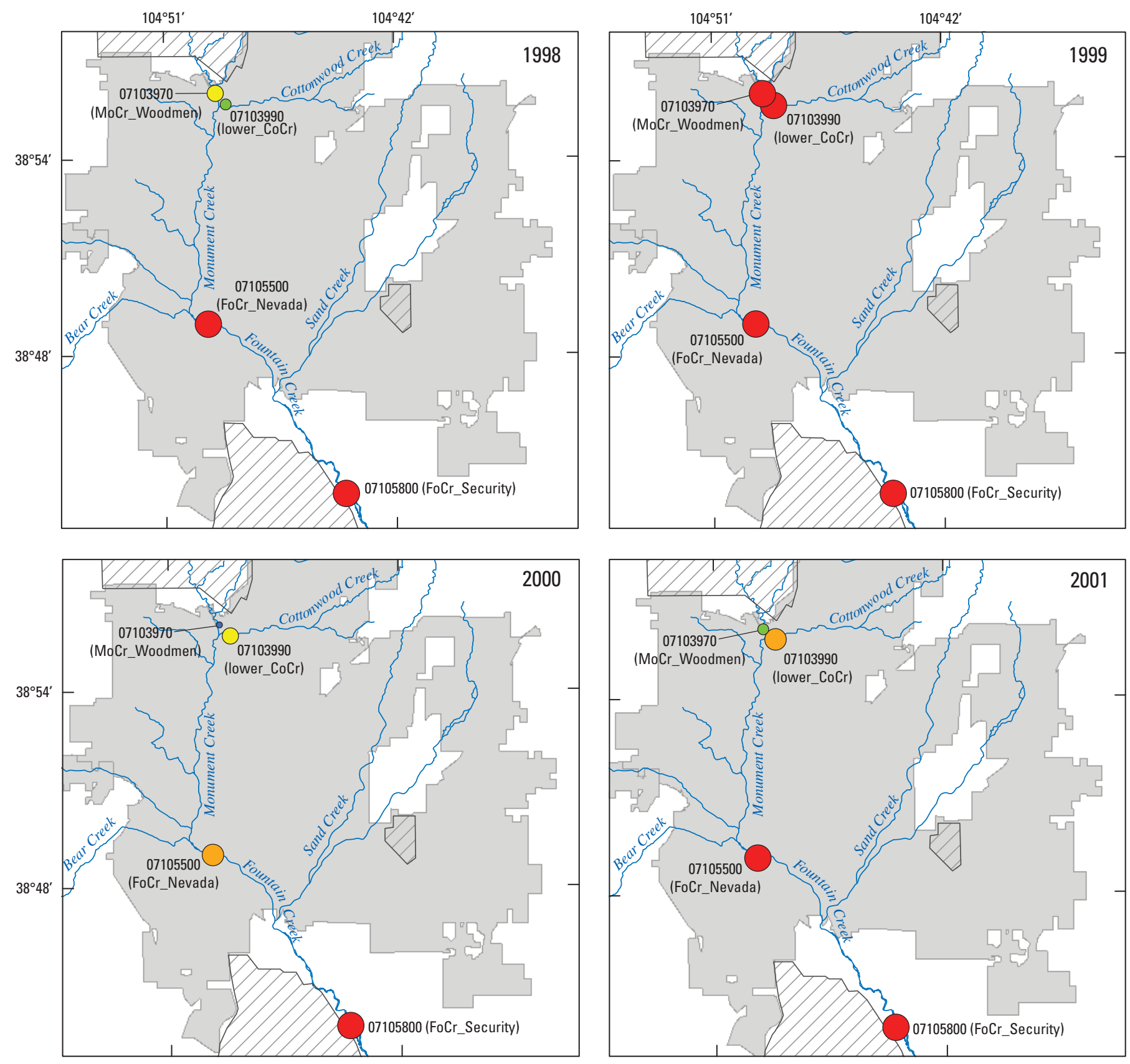

Base from U.S. Geological Survey Albers Equal-Area Conic projection Standard parallels $37^{\circ} 30^{\prime} \mathrm{N}$ and $40^{\circ} 30^{\prime} \mathrm{N}$

Central meridian $105^{\circ} 00^{\prime} \mathrm{W}$

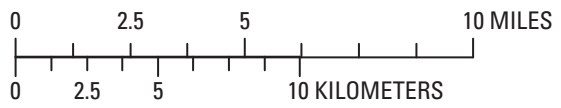

EXPLANATION

Military base or reservation Municipal area

Suspended-sediment discharge, in tons, times 1,000

- Less than 5

○ 5 to 10

○ 10.01 to 20

○ 20.01 to 50

Greater than 50

Figure 21. Cumulative suspended-sediment discharge in the Fountain and Monument Creek watersheds, 1998 through 2001. 

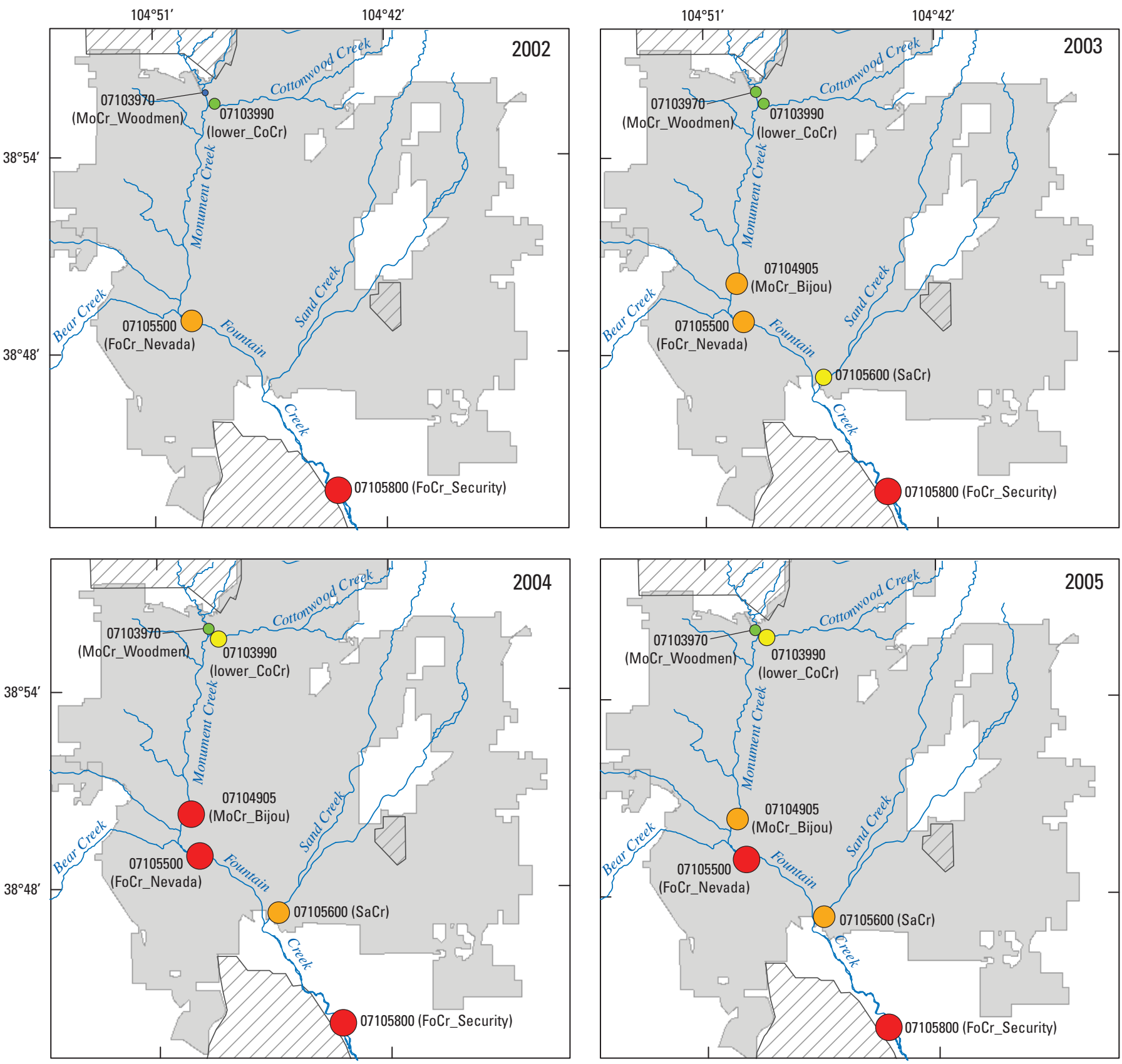

Base from U.S. Geological Survey Albers Equal-Area Conic projection Standard parallels $37^{\circ} 30^{\prime} \mathrm{N}$ and $40^{\circ} 30^{\prime} \mathrm{N}$

Central meridian $105^{\circ} 00^{\prime} \mathrm{W}$

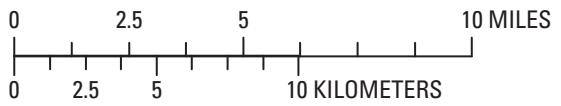

EXPLANATION

Military base or reservation Municipal area

Suspended-sediment discharge, in tons, times 1,000

- Less than 5

○ 5 to 10

○ 10.01 to 20

○ 20.01 to 50

Greater than 50

Figure 22. Cumulative suspended-sediment discharge in the Fountain and Monument Creek watersheds, 2002 through 2005. 
Table 7. Cumulative suspended-sediment discharge in the Fountain and Monument Creek watersheds, annually between April 1 and September 30, 1998, through 2005.

\begin{tabular}{|c|c|c|}
\hline Site number & $\begin{array}{l}\text { Suspended- } \\
\text { sediment } \\
\text { discharge, } \\
\text { in tons per day }\end{array}$ & $\begin{array}{l}\text { Relative percent } \\
\text { contribution of suspended- } \\
\text { sediment discharge to next } \\
\text { downstream site }\end{array}$ \\
\hline \multicolumn{3}{|c|}{1998} \\
\hline 07103970 & 11,800 & 17 \\
\hline 07103990 & 9,630 & 14 \\
\hline 07105500 & 69,400 & 48 \\
\hline 07105800 & 144,000 & \\
\hline \multicolumn{3}{|c|}{1999} \\
\hline 07103970 & 141,000 & 20 \\
\hline 07103990 & 65,700 & 9 \\
\hline 07105500 & 715,000 & 72 \\
\hline 07105800 & 999,000 & \\
\hline \multicolumn{3}{|c|}{2000} \\
\hline 07103970 & 3,960 & 9 \\
\hline 07103990 & 19,700 & 45 \\
\hline 07105500 & 43,800 & 70 \\
\hline 07105800 & 62,500 & \\
\hline \multicolumn{3}{|c|}{2001} \\
\hline 07103970 & 6,500 & 7 \\
\hline 07103990 & 23,100 & 24 \\
\hline 07105500 & 98,000 & 46 \\
\hline 07105800 & 212,000 & \\
\hline \multicolumn{3}{|c|}{2002} \\
\hline 07103970 & 2,890 & 10 \\
\hline 07103990 & 8,250 & 28 \\
\hline 07105500 & 29,800 & 45 \\
\hline 07105800 & 66,400 & \\
\hline
\end{tabular}

\begin{tabular}{|c|c|c|}
\hline Site number & $\begin{array}{l}\text { Suspended- } \\
\text { sediment } \\
\text { discharge, } \\
\text { in tons per day }\end{array}$ & $\begin{array}{c}\text { Relative percent } \\
\text { contribution of suspended- } \\
\text { sediment discharge to next } \\
\text { downstream site }\end{array}$ \\
\hline \multicolumn{3}{|c|}{2003} \\
\hline 07103970 & 7,770 & 18 \\
\hline 07103990 & 7,510 & 18 \\
\hline 07104905 & 42,300 & 98 \\
\hline 07105500 & 43,300 & 77 \\
\hline 07105600 & 12,900 & 23 \\
\hline 07105800 & 56,500 & \\
\hline \multicolumn{3}{|c|}{2004} \\
\hline 07103970 & 6,890 & 14 \\
\hline 07103990 & 14,800 & 30 \\
\hline 07104905 & 50,000 & 60 \\
\hline 07105500 & 83,400 & 71 \\
\hline 07105600 & 35,000 & 30 \\
\hline 07105800 & 118,000 & \\
\hline \multicolumn{3}{|c|}{2005} \\
\hline 07103970 & 6,400 & 13 \\
\hline 07103990 & 11,600 & 24 \\
\hline 07104905 & 48,700 & 81 \\
\hline 07105500 & 60,200 & 73 \\
\hline 07105600 & 31,000 & 37 \\
\hline 07105800 & 82,700 & \\
\hline
\end{tabular}


Table 8. Median suspended-sediment yield during base flow, normal flow, and stormflow in the Fountain and Monument Creek watersheds, and p-values of Mann-Whitney test of significance of spatial variations in suspended-sediment yields.

[Shaded cells indicate test is significant]

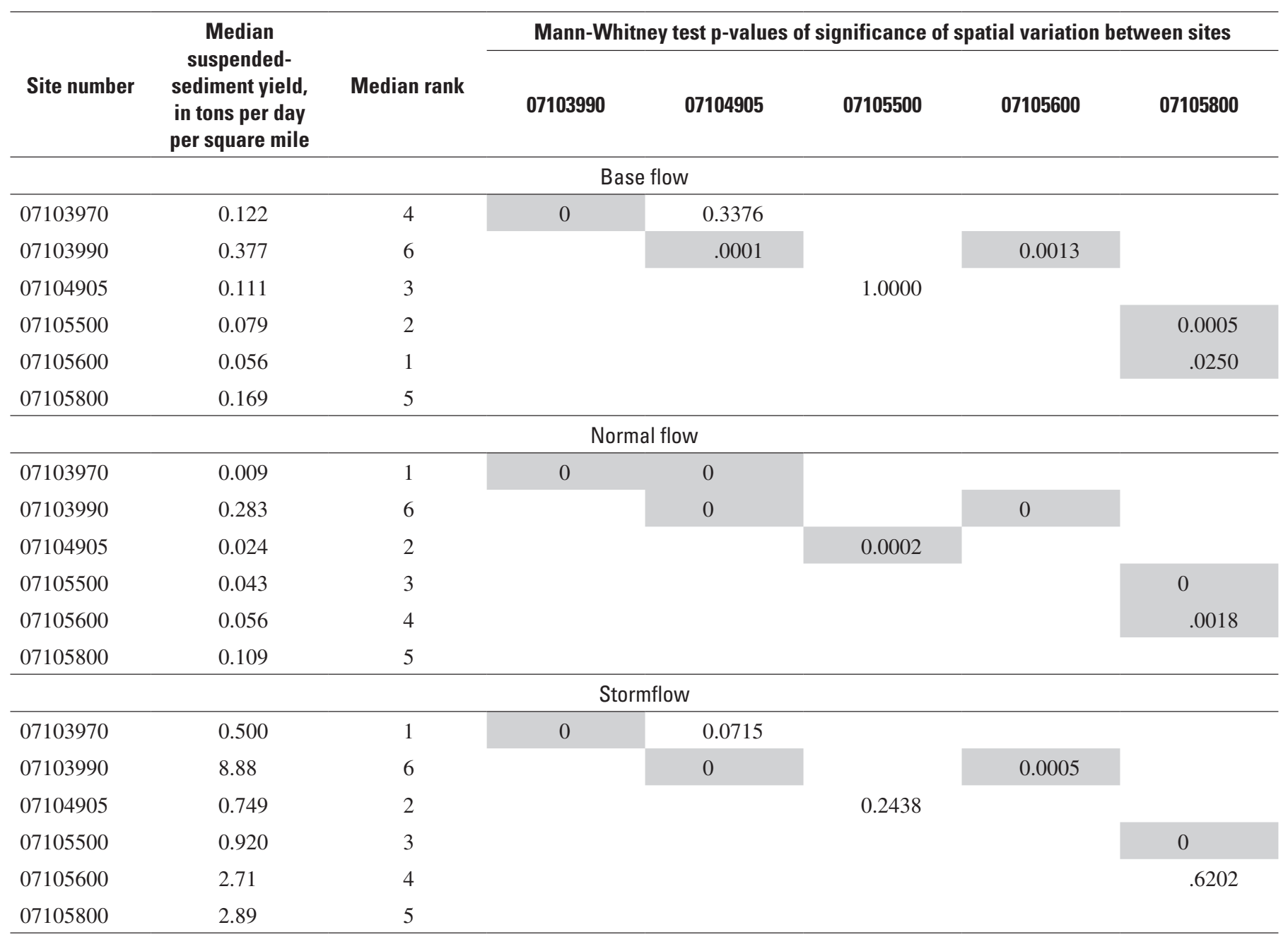


Median suspended-sediment yields at site 07103990 (lower_CoCr) were significantly larger than median suspended-sediment yields at site 07103970

(MoCr_Woodmen) and site 07104905 (MoCr_Bijou) (table 8). Spatial variations in suspended-sediment yields between sites 07104905 (MoCr_Bijou) and 07105500 (FoCr_Nevada) showed no significant differences during base flow (fig. 20C, table 8). Suspended-sediment yields increased significantly between sites 07105500 (FoCr_Nevada) and 07105800 (FoCr_Security) and between sites 07105600 (SaCr) and 07105800 (FoCr_Security) during base flow.

\section{Normal Flow and Stormflow}

During normal flow, the smallest yields were computed at site 07103970 (MoCr_Woodmen) (drainage area of $180 \mathrm{mi}^{2}$ ), and the yields ranged from 0.003 to $0.06 \mathrm{ton} / \mathrm{d} / \mathrm{mi}^{2}$ (fig. 20C). Site 07103990 (lower_CoCr) (drainage area of $18.7 \mathrm{mi}^{2}$ ) had the largest suspended-sediment yields, 0.2 to $0.8 \mathrm{ton} / \mathrm{d} / \mathrm{mi}^{2}$. Suspended-sediment yields increased progressively from site 07104905 (MoCr_Bijou) to site 07105800 (FoCr_Security) along the main-stem of Fountain and Monument Creeks. Analysis of the data between sites indicated that suspended-sediment yields varied by more than an order of magnitude during normal flow but generally were small. Although large spatial variations in suspendedsediment yields occurred during normal flow, the suspendedsediment yields that were associated with stormflow generally were more than 10 times larger than the suspended-sediment yields that occurred during normal flow.

A Mann-Whitney test of differences in median suspended-sediment yields between sites indicated significant $(\mathrm{p}<0.05)$ differences between all sites during normal flow and selected sites during stormflow (table 8). Median suspendedsediment yields increased progressively from site 07103970 (MoCr_Woodmen) to 07105800 (FoCr_Security) along the main-stem of Fountain and Monument Creeks during normal flow and stormflow (fig. 20C). Median suspendedsediment yields at site 07103990 (lower_CoCr), which drains the Colorado Piedmont physiographic region (fig. 1), were larger than median yields at all sites during normal flow and stormflow, indicating the significance of Cottonwood Creek as a sediment source to Monument Creek and, ultimately, Fountain Creek (fig. 20C). Differences in median suspendedsediment yields between sites $07105600(\mathrm{SaCr})$ and 07105800 (FoCr_Security) were significant during normal flow but insignificant during stormflow ( $\mathrm{p}>0.05$ ) (table 8 ). The insignificant differences in yields during stormflow between sites $07105600(\mathrm{SaCr})$ and 07105800 (FoCr_Security) indicate that yields from Sand Creek (area of $52.6 \mathrm{mi}^{2}$ ) are comparable to yields at site 07105800 (FoCr_Security) (area of $499 \mathrm{mi}^{2}$ ).

\section{Variations in Instantaneous Streamflow, Suspended-Sediment Concentration, Suspended-Sediment Discharge, and Suspended-Sediment Yield at Selected Tributaries in the Fountain and Monument Creek Watersheds}

Instantaneous suspended-sediment samples were collected at selected ungaged tributaries to better characterize the spatial variability of suspended sediment in the Fountain and Monument Creek watersheds. An ungaged site does not contain stream-stage recording equipment and was visited less frequently than the gaged sites, usually twice per year during normal flow and once per year during stormflow, to measure streamflow and collect water-quality and suspended-sediment samples. Due to the scope of sample collection at ungaged tributaries and the relatively short sampling period (2003 through 2005), the number of samples collected and statistical tests available to analyze results were limited. Ungaged sites included previously gaged sites in the Cottonwood Creek watershed (sites 07103977, 07103980, and 07103985), Kettle Creek watershed (site 07103960), and nine additional sites on eight other tributaries that were added to the monitoring network prior to April 2003 (fig. 1). Tributaries varied in total area, physiographic region, and surficial geology.

Due to the relatively small drainage areas of the ungaged tributaries and the relatively small geographic extent of summertime convectional storms, storm runoff was very flashy, rising and falling rapidly. Measured streamflow at ungaged sites during normal flow was variable from site to site and generally was less than $10 \mathrm{ft}^{3} / \mathrm{s}$. Streamflow measured during stormflow ranged from about $0.8 \mathrm{ft}^{3} / \mathrm{s}$ to about $1,000 \mathrm{ft}^{3} / \mathrm{s}$. Stormflow duration information is limited for the ungaged tributaries; however, anecdotal evidence from field personnel collecting water-quality and suspended-sediment samples suggests that stormflow durations generally are less than 30 minutes to an hour at most sites for most convective storms.

\section{Suspended-Sediment Concentrations at Selected Tributaries in the Fountain and Monument Creek Watersheds during Normal Flow and Stormflow}

Suspended-sediment concentrations during normal flow varied considerably at individual sites and spatially between sites with median concentrations varying between $1 \mathrm{mg} / \mathrm{L}$ to greater than $1,000 \mathrm{mg} / \mathrm{L}$ (fig. 23). The largest range in suspended-sediment concentrations during normal flow was at 
site 07103980 (middle_CoCr). Site 07103980 (middle_CoCr) drains approximately $10.2 \mathrm{mi}^{2}$ in the Colorado Piedmont physiographic region. Sites in the Colorado Piedmont and draining to Fountain and Monument Creeks from the east generally had the largest suspended-sediment concentrations. Sites in the Colorado Piedmont and Southern Rocky Mountains physiographic regions and draining to Fountain and Monument Creeks from the west generally had smaller suspended-sediment concentrations.

Suspended-sediment concentrations measured during stormflow varied at individual sites and spatially between sites with median concentrations ranging from 10 to more than $10,000 \mathrm{mg} / \mathrm{L}$ (fig. 23). The largest concentrations were measured in Kettle Creek, Cottonwood Creek, and Sand Creek, which drain the Colorado Piedmont from the east of Fountain and Monument Creeks, and North Rockrimmon Creek, which drain the Colorado Piedmont from the west of Monument Creek. Suspended-sediment concentrations during stormflow at sites draining the Colorado Piedmont ranged from about 800 to about $60,000 \mathrm{mg} / \mathrm{L}$. Suspended-sediment concentrations at sites draining the Southern Rocky Mountains physiographic province (Bear Creek sites 07105000 and 384909104504401 ) ranged from about 10 to about $1,000 \mathrm{mg} / \mathrm{L}$ (fig. 23); however, these data are based on a small number of storm samples from sites draining the Southern Rocky Mountains physiographic province.

\section{Suspended-Sediment Discharges at Selected Tributaries in the Fountain and Monument Creek Watersheds during Normal Flow and Stormflow}

Suspended-sediment discharge varied between sites during normal flow (fig. 24). Streamflows at sites with suspended-sediment discharges larger than 1 ton/d generally was larger than $1 \mathrm{ft}^{3} / \mathrm{s}$ during normal flow. Streamflow during normal flow at sites with suspended-sediment discharge less than 1 ton/d generally was less than $1 \mathrm{ft}^{3} / \mathrm{s}$. Suspendedsediment discharge during normal flow was less than 1 ton/d at sites on Kettle, Pine, Mesa, and Bear Creeks and unnamed tributaries to Monument and Cottonwood Creeks. Suspended-sediment discharge at sites on Cottonwood, North Rockrimmon, and Sand Creeks were larger than 1 ton/d (fig. 24). Drainage areas of sites with suspended-sediment discharges larger than 1 ton/d varied considerably. North Rockrimmon Creek at site 07104050 (NRCr) has a drainage area of about $1.8 \mathrm{mi}^{2}$, Cottonwood Creek at site 07103990 (lower_CoCr) has a drainage area of about $18.7 \mathrm{mi}^{2}$, and Sand Creek at site $07105600(\mathrm{SaCr})$ has a drainage area of about $52.6 \mathrm{mi}^{2}$. At site 07103985 (TbCo), suspended-sediment discharge during normal flow was smaller than 1 ton/d and it has a drainage area of $2.8 \mathrm{mi}^{2}$.

Suspended-sediment discharge during stormflow varied spatially (fig. 24). Suspended-sediment discharge generally was larger than 100 tons/d at the ungaged tributaries and varied considerably between sites in the Colorado Piedmont and sites in the Front Range of the Colorado Rocky Mountains physiographic regions. Suspended-sediment discharge at sites in the Colorado Piedmont-Cottonwood Creek, Kettle Creek, and Sand Creek-ranged from about 1,000 to about 10,000 tons/d. Suspended-sediment discharge at sites draining from the west in or near the Front Range of the Colorado Rocky Mountains physiographic province generally were less than 10 tons/d.

\section{Suspended-Sediment Yields at Selected Tributaries in the Fountain and Monument Creek Watersheds during Normal Flow and Stormflow}

The analysis of suspended-sediment yields during normal flow revealed that small tributaries such as North Rockrimmon Creek, which has an area of $1.82 \mathrm{mi}^{2}$, contributed as much or more sediment per unit area as larger tributaries, such as Cottonwood Creek with a drainage area of $18.7 \mathrm{mi}^{2}$. Median suspended-sediment yields during normal flow generally were less than $0.1 \mathrm{ton} / \mathrm{d} / \mathrm{mi}^{2}$ (fig. 25) at most sites. Site 385501104483701 (TbMo), an unnamed tributary to Monument Creek near Pulpit Rock with a drainage area of $0.691 \mathrm{mi}^{2}$, had the smallest median suspended-sediment yields, less than $0.001 \mathrm{ton} / \mathrm{d} / \mathrm{mi}^{2}$. Sites $07104050(\mathrm{RkCr})$, with a drainage area of $1.82 \mathrm{mi}^{2}$, and 07103980 (middle_CoCr), with a drainage area of $10.2 \mathrm{mi}^{2}$, had the largest median suspended-sediment yields, larger than $1 \mathrm{ton} / \mathrm{d} / \mathrm{mi}^{2}$. The largest tributary sites, 07103990 (lower_CoCr), with a drainage area of $18.7 \mathrm{mi}^{2}$, and $07105600(\mathrm{SaCr})$, with a drainage area of $52.6 \mathrm{mi}^{2}$, had median suspended-sediment yields of 0.1 to 1 ton $/ \mathrm{d} / \mathrm{mi}^{2}$ and 0.01 to $0.1 \mathrm{ton} / \mathrm{d} / \mathrm{mi}^{2}$, respectively. Spatially, sites draining from the east (Colorado Piedmont) generally had larger median suspended-sediment yields than sites draining from the west.

There was less spatial variation of median suspendedsediment yields of the ungaged tributaries during stormflow (fig. 25). Suspended-sediment yields during stormflow at sites 07103980 (middle_CoCr), 07103985 (TbCo), $385750104475001(\mathrm{PiCr})$, and $07104050(\mathrm{RkCr})$ ranged between 10 and 100 tons $/ \mathrm{d} / \mathrm{mi}^{2}$ of drainage area. Suspendedsediment yields in Sand Creek (drainage area of $52.6 \mathrm{mi}^{2}$ ) were larger than 100 tons $/ \mathrm{d} / \mathrm{mi}^{2}$ during stormflow. Based on the few available data, suspended-sediment yields during stormflow at sites on Kettle, Pine, North Rockrimmon, and Mesa Creeks are comparable to Cottonwood and Sand Creeks.

\section{Stream Morphology}

Stream channels naturally change over time in response to streamflow characteristics and sediment delivery from the surrounding watershed. Change in streamflow characteristics and (or) sediment delivery from the surrounding watershed will in turn initiate a series of responses as the channel adjusts 

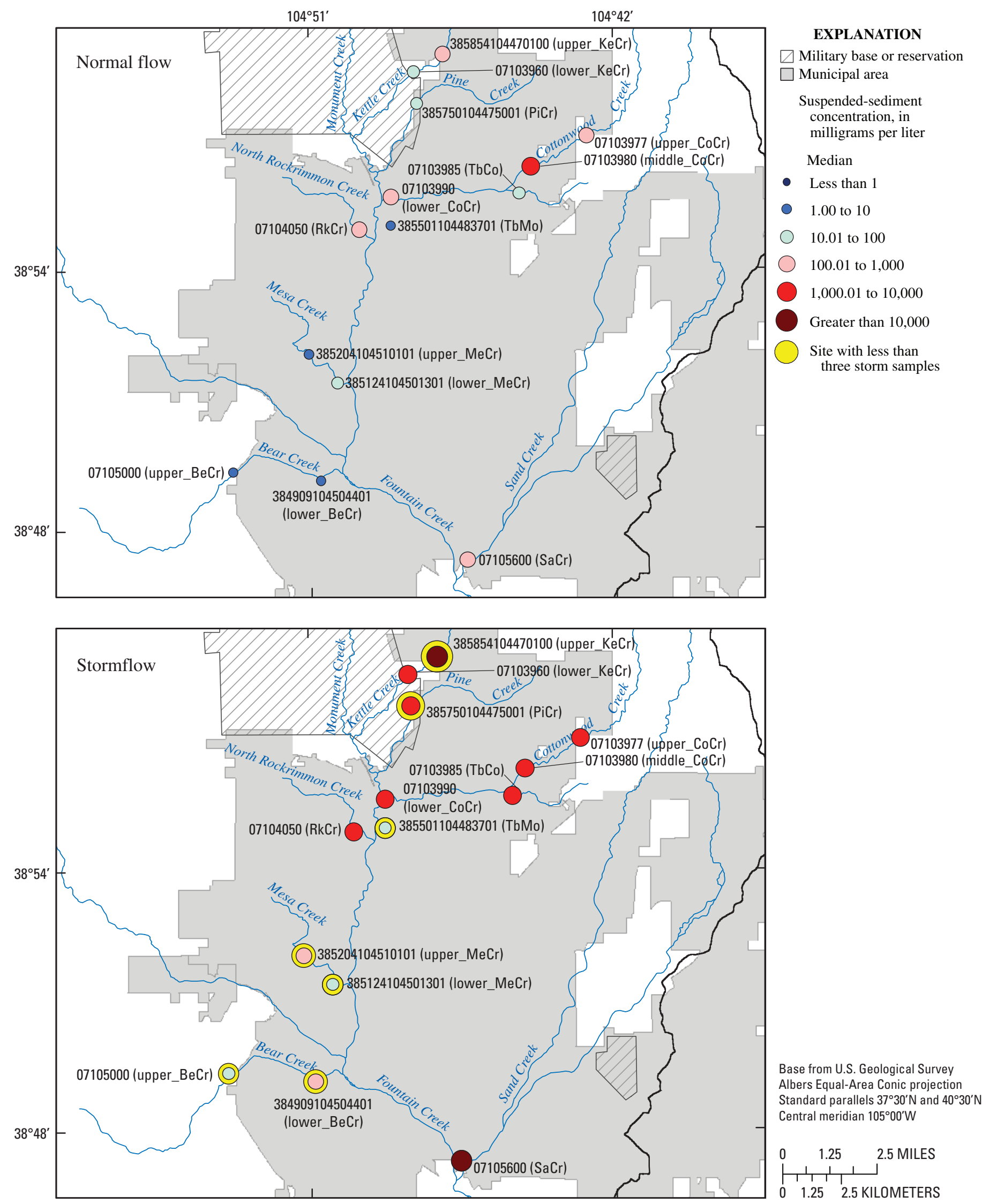

Figure 23. Variations in suspended-sediment concentration during normal flow and stormflow at selected tributaries in the Fountain and Monument Creek watersheds. 


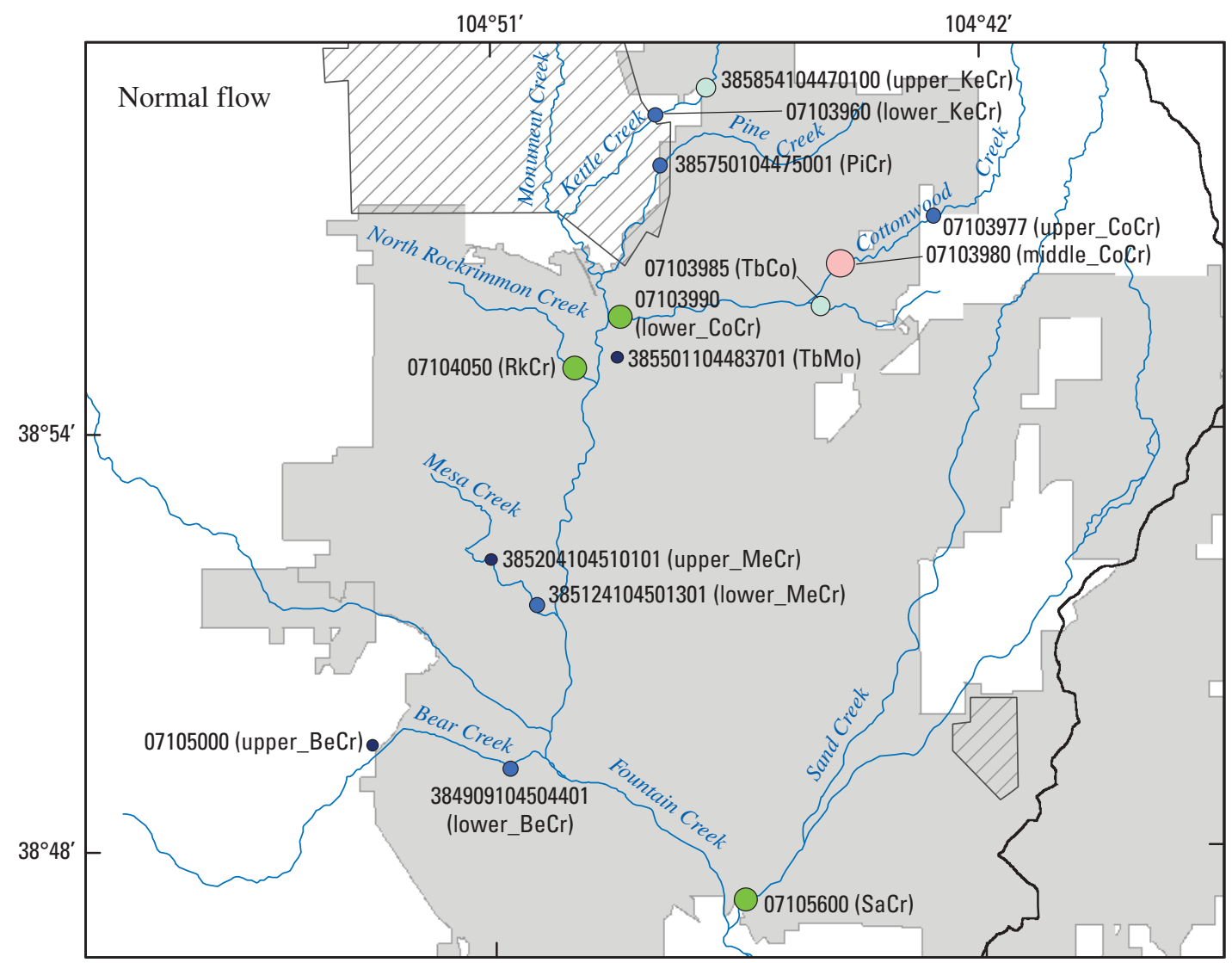

\section{EXPLANATION}

$\triangle$ Military base or reservation

$\square$ Municipal area

Suspended-sediment concentration, in tons per day

Median

- Less than 0.01

- 0.01 to 0.1

○ $\quad 0.11$ to 1.0

- 1.01 to 10

( 10.01 to 100

100.01 to 1,000

Greater than 1,000

Site with less than three storm samples

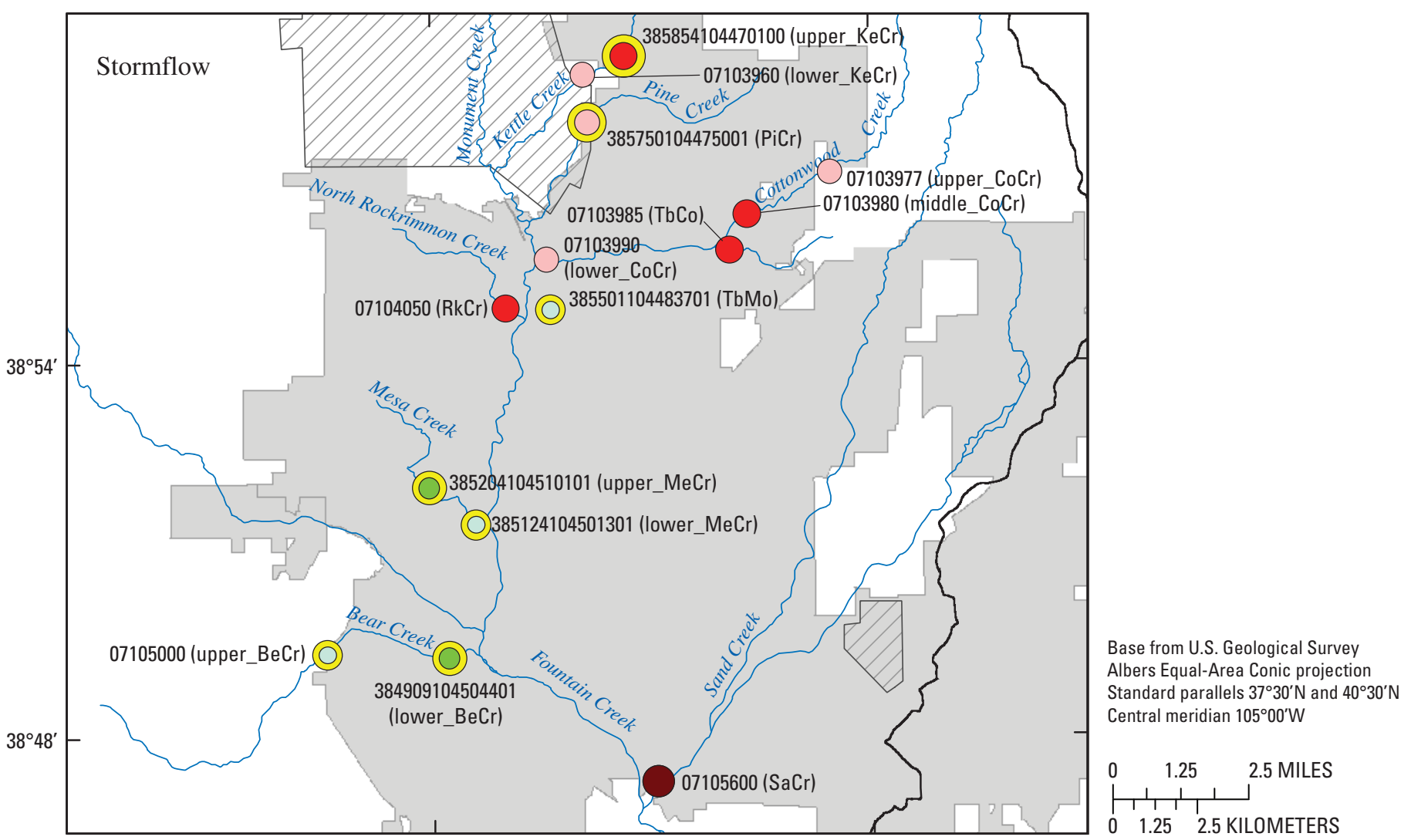

Figure 24. Variations in suspended-sediment discharge during normal flow and stormflow at selected tributaries in the Fountain and Monument Creek watersheds. 


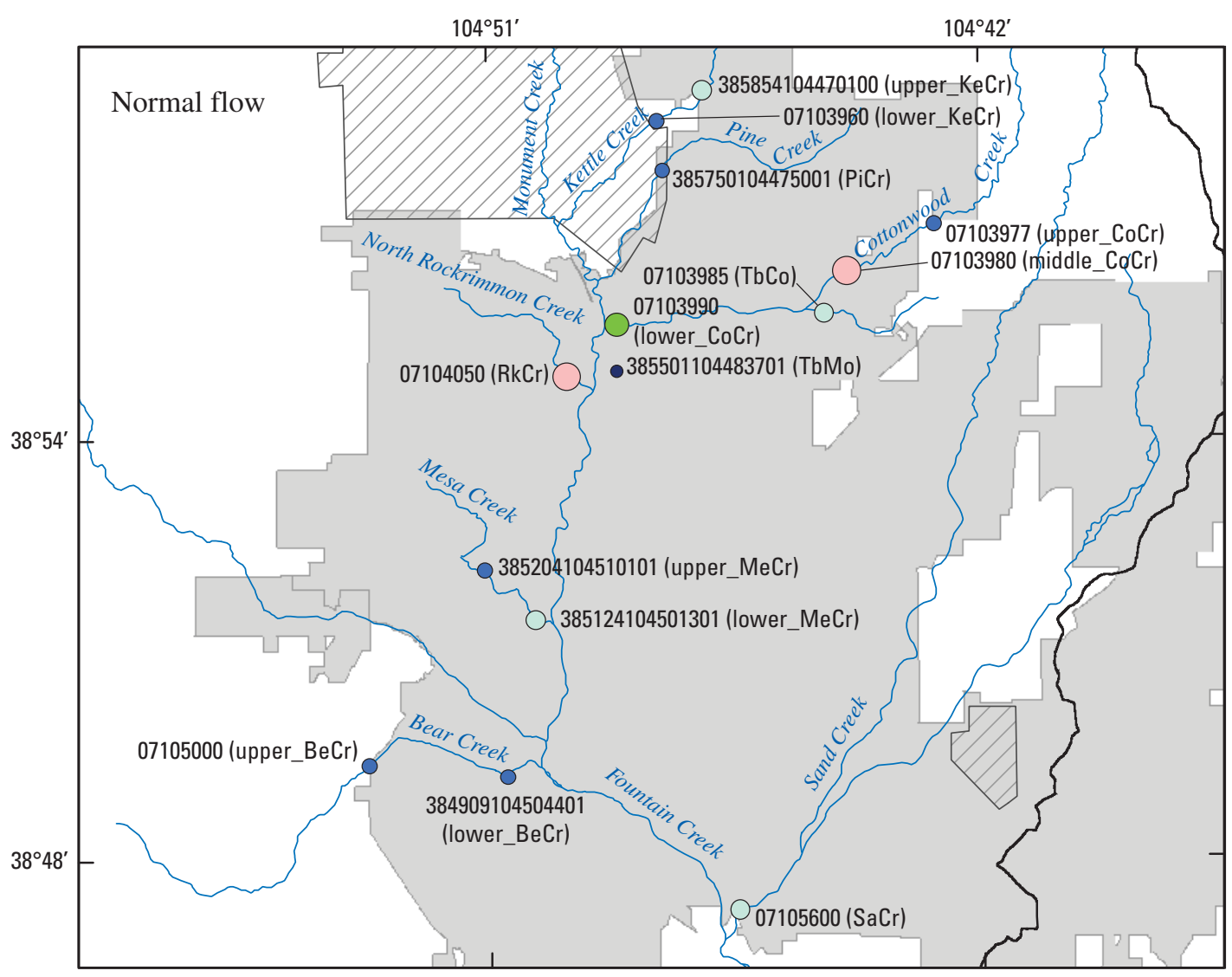

\section{EXPLANATION}

$\square \quad$ Military base or reservation

$\square$ Municipal area

Suspended-sediment concentration, in

tons per day

Median

- Less than 0.01

- 0.01 to 0.1

○ $\quad 0.11$ to 1.0

- 1.01 to 10

- 10.01 to 100

100.01 to 1,000

Greater than 1,000

Site with less than three storm samples

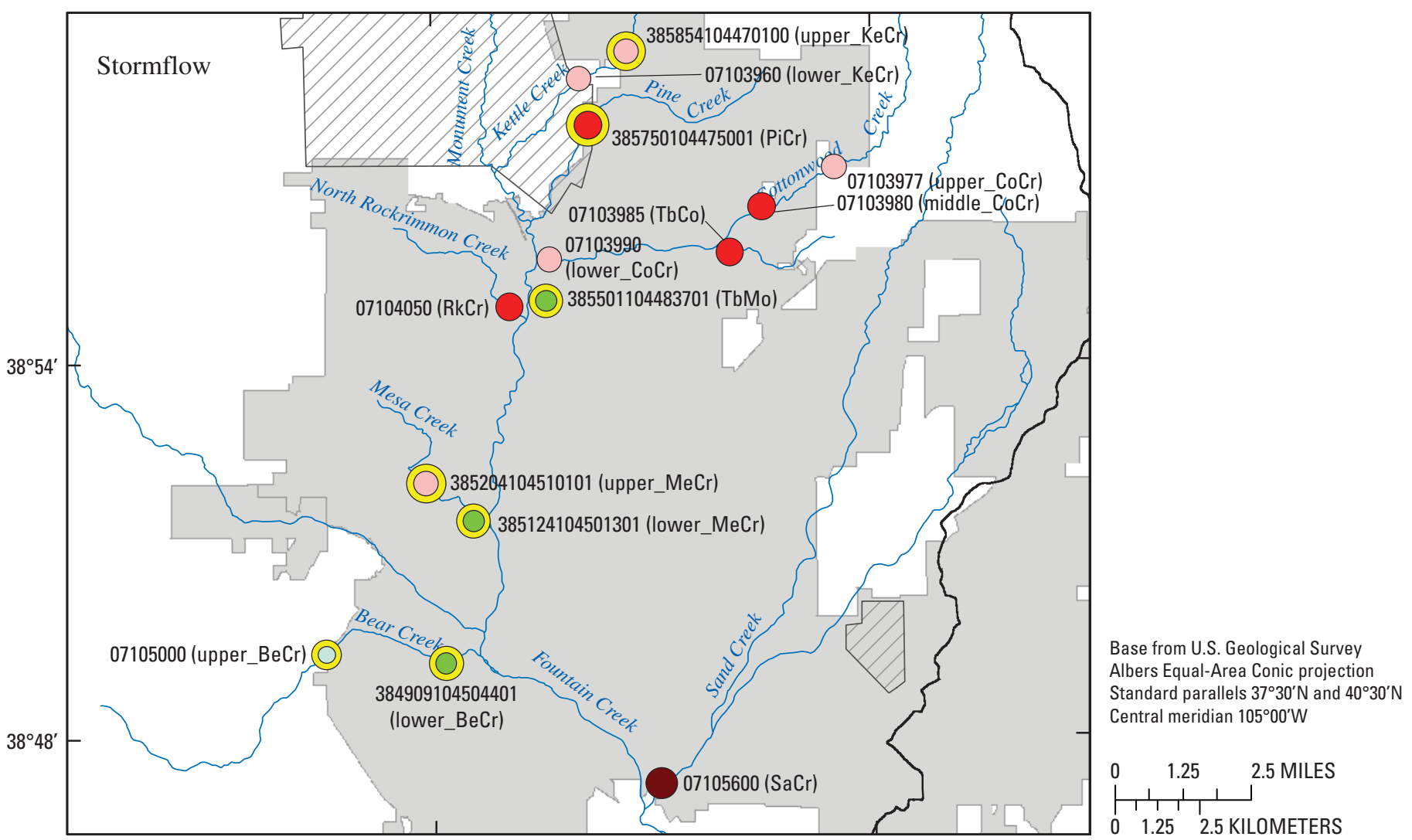

Figure 25. Variations in suspended-sediment yield during normal flow and stormflow at selected tributaries in Fountain and Monument Creek watersheds. 
to those changes (Leopold and others, 1964; Schumm, 1977; Karlinger and others, 1983).

\section{Sediment-Transport Capacity}

The ability of streamflow to transport sediment (transport capacity) can be described by using the Shields dimensionless shear-stress relation for estimating the particle size of bed material at the threshold of movement (von Guerard, 1989b). Maximum particle sizes of bed material transportable at various streamflows were estimated by using the following equation (von Guerard, 1989b; Elliott and others, 1984):

$$
d_{c}=\left(\frac{\bar{D} S}{\left(\left(\frac{\gamma_{s}}{\gamma_{w}}\right)-1\right) \tau_{c}^{*}}\right)^{(304.8)}
$$

where

$$
\begin{array}{cc}
d_{c} & \begin{array}{c}
\text { is particle size of bed material, at threshold of } \\
\text { movement, in millimeters; }
\end{array} \\
\bar{D} & \text { is mean channel depth, in feet; } \\
S & \text { is water-surface slope, dimensionless; } \\
\frac{\gamma_{s}}{\gamma_{w}} & \begin{array}{c}
\text { is ratio of specific weights of sediment and } \\
\text { water (2.65), dimensionless; }
\end{array} \\
\tau_{c}^{*} & \begin{array}{c}
\text { is critical shear stress - the critical shear stress } \\
\text { necessary for movement of bed material, }
\end{array} \\
304.8 \quad \begin{array}{c}
\text { dimensionless; and } \\
\text { is unit conversion constant, in millimeters } \\
\text { per foot. }
\end{array}
\end{array}
$$

Values of $\tau^{*}{ }_{c}$ of 0.030 and 0.045 were used as the upper and lower limits for the transport of coarse materials in Fountain Creek.

Streamflow (data from NWIS) and channel morphology data at sites on Cottonwood (07103980 (middle_CoCr), 07103985 (Tb_Co), and 07103990 (lower_CoCr)); Kettle (07103960); Bear (07105000); Monument (07103970 (MoCr_Woodmen) and 07104905 (MoCr_Bijou)); and Fountain (07103700 (FoCr_Manitou), 07105500 (FoCr_Nevada), 07105530 (FoCr_Janitell), and 07105800 (FoCr_Security)) Creeks were used to evaluate the capacity of streamflows to transport coarse sand and gravel of 1- to 32-mm-size fractions, the predominant size fraction in Fountain, Monument, and Cottonwood Creeks (table 9) (Harrelson and others, 1994; Wolman, 1954). Analyses indicate that minimum measured streamflows at all sites have the capacity (table 10) to transport coarse to very coarse sands of 1 to $2 \mathrm{~mm}\left(\tau^{*}=0.045\right)$. The transport of bed material of the coarse gravel of 16- to 32-mm-size fractions is possible $\left(\tau_{c}^{*}=0.045\right)$ as streamflows approach and exceed $20 \mathrm{ft}^{3} / \mathrm{s}$ to $30 \mathrm{ft}^{3} / \mathrm{s}$ at sites in the Cottonwood Creek watershed, 07103980 (middle_CoCr), 07103985 (TbCo), and 07103990
(lower_CoCr); and $130 \mathrm{ft}^{3} / \mathrm{s}$ to $150 \mathrm{ft}^{3} / \mathrm{s}$ at site 07103970 (MoCr_Woodmen), $130 \mathrm{ft}^{3} / \mathrm{s}$ to $250 \mathrm{ft}^{3} / \mathrm{s}$ at site 07104905 (MoCr_Bijou) in Monument Creek; $5 \mathrm{ft}^{3} / \mathrm{s}$ to $10 \mathrm{ft}^{3} / \mathrm{s}$ at site 07103700 (FoCr_Manitou), $50 \mathrm{ft}^{3} / \mathrm{s}$ to $120 \mathrm{ft}^{3} / \mathrm{s}$ at site 07105500 (FoCr_Nevada), $100 \mathrm{ft}^{3} / \mathrm{s}$ to $200 \mathrm{ft}^{3} / \mathrm{s}$ at site 07105530 (FoCr_Janitell), and $130 \mathrm{ft}^{3} / \mathrm{s}$ to $600 \mathrm{ft}^{3} / \mathrm{s}$ at site 07105800 (FoCr_Security) in Fountain Creek. The maximum measured streamflows at sites 07103700 (FoCr_Manitou), 07103990 (lower_CoCr), 07105000 (upper_BeCr), and 07105500 (FoCr_Nevada) also have sufficient energy to initiate movement of bed material in the cobble-size fraction (64 to $256 \mathrm{~mm})\left(\tau^{*}{ }_{c}=0.045\right)$.

\section{Descriptive Assessment of Changes in Channel Morphology}

Substantial changes in channel morphology are most often associated with infrequent or catastrophic floods that may cause rapid changes in channel shape and (or) location and capture the attention of area residents. However, more common streamflow conditions associated with bankfull streamflow, while less catastrophic, are considered the dominant force in development and maintenance of channel morphology (Leopold and others, 1964; Wolman and Miller, 1960). Changes in channel morphology for one reach of Monument Creek near site 07103970 (MoCr_Woodmen), two reaches of Fountain Creek near sites 07103700 (FoCr_Manitou) and 07105800 (FoCr_Security), four reaches of Cottonwood Creek near sites 07103977 (upper_CoCr), 07103980 (middle_CoCr), 07103985 (TbCo), and 07103990 (lower_CoCr), and one reach of Sand Creek (07105600) are described using periodic cross-section surveys made by Colorado Springs City Engineering employees from 1999 through 2005 (Joel Mackey, Colorado Springs City Engineering, unpub. data, 2006). In addition to surveys of selected reaches conducted by City of Colorado Springs City Engineering employees, individual cross sections at or near sites 07104000 (MoCr_Pikeview), 07104905 (MoCr_Bijou), and 07105530 (FoCr_Janitell) were surveyed (Kennedy, 1990) periodically by USGS employees. Cross-section surveys documented channel downcutting, channel aggradation or infilling, and bank scour that have occurred between 1999 and 2005.

Bulk density of bed materials in Fountain and Monument Creeks was not determined as part of this investigation. Sediment deposits analogous to the sand and gravel composition of the beds of Fountain and Monument Creeks and their tributaries would undoubtedly vary considerably depending on horizontal and vertical particle-size distribution and other factors such as compaction. Anderson (1973) and Meade (1985) suggest that bulk densities of sand and gravel mixtures range from 60 to $100 \mathrm{lb} / \mathrm{ft}^{3}$.

For the purpose of this report, cross-section area refers to the cross-section sediment area (fig. 26) above an arbitrary datum within the surveyed cross section. Sediment volume 


\section{Stormflows and Wastewater Treatment-Plant Effluent Discharges, Colorado Springs, Colorado, 1981-2006}

Table 9. Particle-size distribution for bed material at sites in the Fountain and Monument Creek watersheds based on pebble counts measured between 1998 and 2005.

$[<$, less than; $>$, greater than; percentages may not equal 100 because of rounding]

\begin{tabular}{|c|c|c|c|c|c|c|}
\hline \multirow{5}{*}{ Site number } & \multicolumn{6}{|c|}{ Size class (Wentworth) ${ }^{2}$} \\
\hline & Silt/Clay & Sand & Gravel & Cobble & Boulder $^{3}$ & Bedrock $^{3}$ \\
\hline & \multicolumn{6}{|c|}{ Range in particle size, in millimeters } \\
\hline & $<0.0625$ & $0.0625-2$ & $2-64$ & $64-256$ & $256-4,096$ & $>4,096$ \\
\hline & \multicolumn{6}{|c|}{ in percent } \\
\hline \multicolumn{7}{|c|}{ Tributaries } \\
\hline 385854104470100, upper_KeCr & 33 & 45 & 22 & 0 & 0 & 0 \\
\hline 07103960, lower_KeCr & 34 & 40 & 24 & 1 & 0 & 1 \\
\hline 385750104475001, PiCr & 32 & 46 & 19 & 1 & 0 & 3 \\
\hline $07103976^{1}$ & 8 & 45 & 46 & 0 & 0 & 0 \\
\hline $07103978^{1}$ & 24 & 52 & 21 & 0 & 0 & 3 \\
\hline 07103980, middle_CoCr & 10 & 44 & 28 & 0 & 2 & 15 \\
\hline 07103985, ТbСo & 11 & 57 & 24 & 4 & 4 & 0 \\
\hline 07103990, lower_CoCr & 7 & 32 & 21 & 1 & 5 & 34 \\
\hline 385501104483701, TbMo & 29 & 42 & 21 & 2 & 6 & 1 \\
\hline 385204104510101, upper_MeCr & 60 & 6 & 25 & 3 & 1 & 5 \\
\hline 385124104501301, lower_MeCr & 71 & 8 & 16 & 4 & 0 & 0 \\
\hline 07105000, upper_BeCr & 21 & 16 & 44 & 6 & 13 & 0 \\
\hline \multicolumn{7}{|c|}{ Main stem } \\
\hline 07103700,FoCr_Manitou & 13 & 27 & 40 & 13 & 8 & 0 \\
\hline 07103707, FoCr_8th & 13 & 45 & 32 & 5 & 6 & 0 \\
\hline 07103970, MoCr_Woodmen & 13 & 36 & 46 & 3 & 1 & 2 \\
\hline 07104905, MoCr_Bijou & 7 & 54 & 38 & 0 & 1 & 1 \\
\hline 07105500, FoCr_Nevada & 8 & 42 & 39 & 2 & 9 & 0 \\
\hline 07105530, FoCr_Janitell & 8 & 31 & 29 & 8 & 19 & 5 \\
\hline 07105800, FoCr_Security & 8 & 33 & 42 & 3 & 4 & 9 \\
\hline
\end{tabular}

${ }^{1}$ Site numbers 07103976 and 07103978 are unofficial site numbers and represent sites located immediately upstream and downstream from site 07103977 (upper_CoCr).

${ }^{2}$ Dunne, Thomas, and Leopold, L.B., 1978, Water in environmental planning: New York, W.H. Freeman and Company, 818 p.; and Gordon, Nancy D., McMahon, Thomas A., Finlayson, Brian L., Gippel, Christopher J., and Nathan, Rory J., 2004, Stream hydrology, an introduction for ecologists: West Sussex, John Wiley and Sons, Ltd., 429 p.

${ }^{3}$ Modified size classes for this report. 
Table 10. Range in particle size of bed material, in millimeters, at threshold of movement for upper and lower limits of transport of coarse materials based on minimum and maximum measured streamflow in the Fountain and Monument Creek watersheds.

$\left[\tau_{c}^{*}\right.$, critical shear stress necessary to initiate movement of bed material, dimensionless; 0.030 , upper limit of $\tau_{c}^{*} ; 0.045$ lower limit of $\tau_{c}^{*} ;$ mm, millimeters ]

\begin{tabular}{|c|c|c|c|c|c|}
\hline \multirow[b]{2}{*}{ Site number } & \multirow[b]{2}{*}{$\begin{array}{c}\text { Channel } \\
\text { slope }\end{array}$} & \multicolumn{4}{|c|}{$\tau_{c}^{*}$} \\
\hline & & $\begin{array}{c}\text { Minimum } \\
\text { particle } \\
\text { size } \\
(\mathrm{mm})\end{array}$ & $\begin{array}{c}\text { Maximum particle } \\
\text { size } \\
(\mathrm{mm})\end{array}$ & $\begin{array}{c}\text { Minimum } \\
\text { particle } \\
\text { size } \\
(\mathrm{mm})\end{array}$ & $\begin{array}{c}\text { Maximum } \\
\text { particle } \\
\text { size } \\
\text { (mm) }\end{array}$ \\
\hline \multicolumn{6}{|c|}{ Tributaries } \\
\hline 07103980, middle_CoCr & .012 & 8.31 & 32.5 & 5.54 & 21.7 \\
\hline 07103985, TbCo & .008 & 7.09 & 46.8 & 4.73 & 31.2 \\
\hline 07103990, lower_CoCr & .020 & 15.9 & 131 & 10.6 & 87.6 \\
\hline 07105000, upper_BeCr & .062 & 42.0 & 175 & 28.0 & 116 \\
\hline 07104905, MoCr_Bijou & .004 & 4.67 & 37.8 & 3.12 & 25.2 \\
\hline 07105500, FoCr_Nevada & .006 & 9.33 & 191 & 6.22 & 128 \\
\hline 07105530, FoCr_Janitell & .005 & 11.1 & 66.8 & 7.36 & 44.5 \\
\hline 07105800, FoCr_Security & .004 & 8.55 & 93.0 & 5.70 & 62.0 \\
\hline
\end{tabular}




\section{Cross-section sediment area}

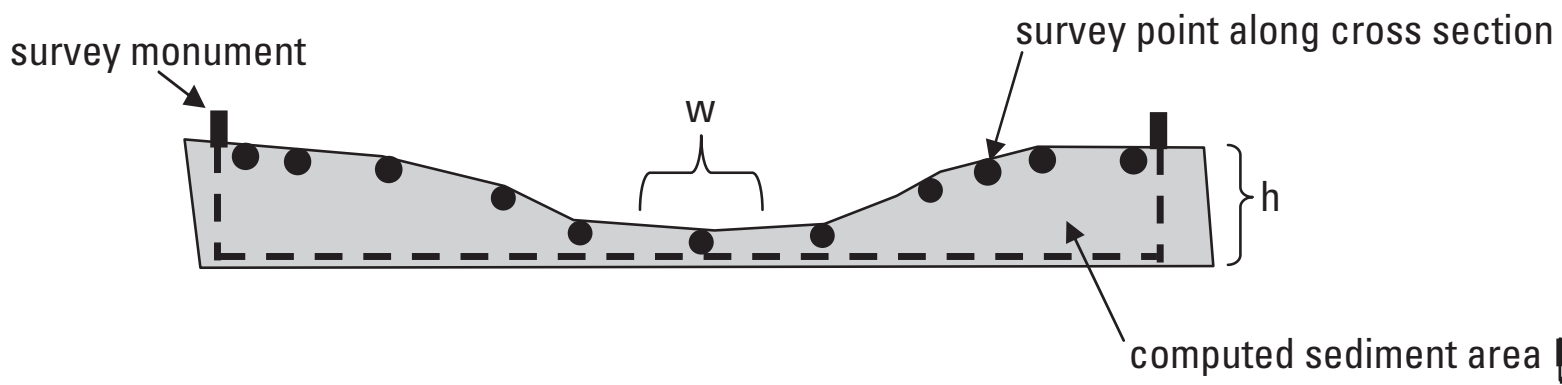

Sediment area $=\sum_{n}^{1}$ surveyed height of sediment $(\mathrm{h}){ }^{*}$ subsection width (w)

subsection width $(w)=\Sigma 1 / 2$ distance between survey points (see above diagram)

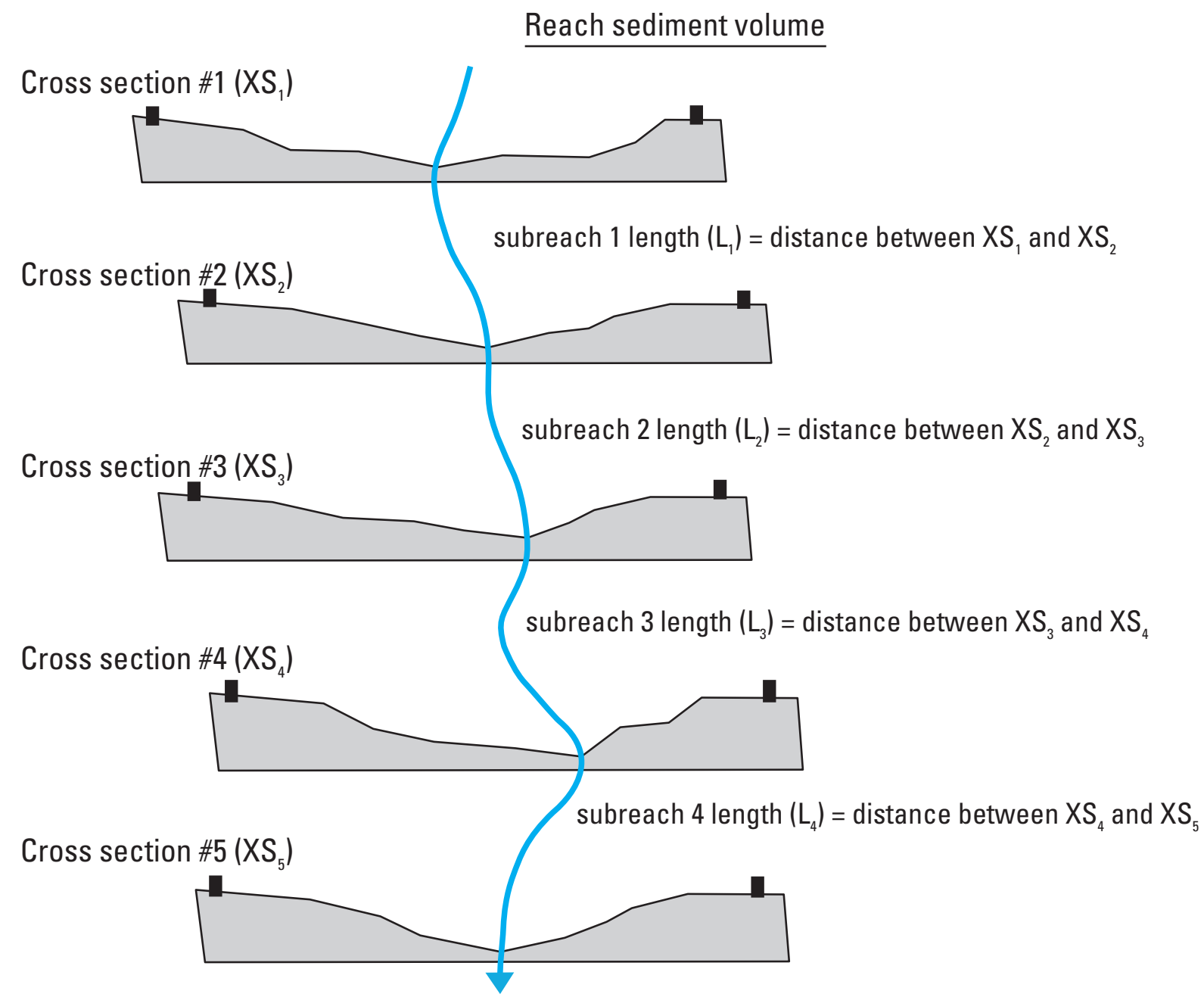

Sediment volume $=$ area $X S_{1} * 1 / 2 L_{1}+$ area $X S_{2} * 1 / 2 L_{1}+$ area $X S_{2} * 1 / 2 L_{2}+\operatorname{area} X S_{3} * 1 / 2 L_{2}+$ area $X S_{3} * 1 / 2 L_{3}$ + area $X S_{4} * 1 / 2 L_{3}+$ area $X S_{4} * 1 / 2 L_{4}+$ area $X S_{5} * 1 / 2 L_{4}$

Figure 26. Computation of cross-section sediment area and reach sediment volume. 
refers to the estimated volume of sediment within the surveyed reach (fig. 26). Data presented with regard to volume of channel downcutting or infilling do not represent total bedload transport for a given period at a given site, only net change in channel volume from one survey period to the next. Therefore, the gains and (or) losses in volume of bed and bank material cannot be used as a surrogate for bedload in conjunction with suspended-sediment data to compute total sediment load for a site.

\section{Cottonwood Creek}

Bed material in the Cottonwood Creek channel ranges from primarily sand and gravel in its upper reaches (site 07103977 [upper_CoCr], referred to as sites 07103976 and 07103978 in table 9) to bedrock and sand at its confluence with Monument Creek (site 07103990 [lower_CoCr]) (table 9). Channel morphology in the upper reach of Cottonwood Creek (07103977 [upper_CoCr]) changed between 1999 and 2005. Surveys of five cross sections along a 219-ft reach indicate channel aggradation and widening and (or) lateral migration. Cross sections aggraded 0.36 to $1.39 \mathrm{ft}$ between October 1999 and October 2005 (fig. 27, table 11). Channel migration is apparent at the upper three cross sections as one bank is aggrading while the opposite bank is eroding. The slope of the channel has increased 0.00165 from 0.02081 to 0.02246 . Increases in the slope of the channel affect sediment-transport characteristics and result in increased transport capacity without an increase in streamflow. The volume of bed and bank material decreased between October 1999 and October 2005 (fig. 28). Bank erosion generally has exceeded channel aggradation with an estimated net loss of about 2,200 $\mathrm{ft}^{3}$ from the reach at site 07103977 (upper_CoCr) during October 1999 to October 2005 (table 12). Based on the probable range in bulk density of sand and gravel deposits and the net change in reach volume, 65.6 to 109 tons has been removed from this reach (table 12) between October 1999 and October 2005.

Changes in channel morphology in the central reach (07103980 [middle_CoCr]) are dominated by channel widening and downcutting. The four most-upstream cross sections indicate widening and channel downcutting while the most-downstream cross section indicates that the channel is widening and infilling. The minimum bed altitude at the four upstream cross sections degraded by 0.55 to $1.37 \mathrm{ft}$, and the downstream cross section aggraded $0.32 \mathrm{ft}$ (table 11), resulting in a 0.00533 decrease in slope through the reach. During the period from October 1999 through October 2005, annual changes in sediment volume have included increases in sediment volume as material was deposited within the reach and decreases as materials were scoured from the reach (fig. 28). As of October 2005, sediment volume within this reach had decreased 9,700 $\mathrm{ft}^{3}$ (fig. 28) (table 12), primarily due to bed and bank erosion in the upstream portion of the reach and bank erosion in the downstream portion. Based on the possible range in bulk density of sand and gravel deposits and the net change in sediment volume, 290 to 480 tons (table 12) of sand and gravel was removed from this reach.

One tributary to Cottonwood Creek (07103985 [TbCo]) also was surveyed to evaluate changes in channel morphology. Cross-section surveys indicate downcutting as the dominant in-channel process; degradation ranged from 0.3 to $1.65 \mathrm{ft}$ (table 11) along the reach. However, flood-plain deposition exceeded in-channel downcutting as the area at one cross section decreased $10.9 \mathrm{ft}^{2}$ and areas at four cross sections increased by 37.8 to $263 \mathrm{ft}^{2}$, and sediment volume increased 22,200 $\mathrm{ft}^{3}$ (table 12) between October 2000 and October 2005 (fig. 28). The slope of the reach decreased 0.00472 as a result of downcutting. Based on the probable range in bulk density of sand and gravel deposits and the net change in sediment volume, 670 to 1,100 tons (table 12) has been deposited mainly in the overbank areas of this reach. Changes measured within this reach may be attributable to the rapid changes in land use within the watershed. Impervious area within the watershed increased 15 percent between 1997 and 2005 , or about 2 percent per year (table 2). Increases in storm runoff generally coincides with increases in imperviousness. Increases in storm runoff likely increases the transport capacity and competence of streamflow. Larger streamflows might explain the downcutting of the bed and likely would result in more frequent overbank flows. Coarse material transported by the larger streamflows would settle out of the water column as velocities decrease in the area of overbank flows because streamflows are generally shallower and slower as resistance to the flow increases due to bank vegetation. The pattern of downcutting and bank deposition is likely to continue until the channel establishes a quasi-equilibrium with the current flow regime and sediment inputs.

Changes in morphology of the lower reach of Cottonwood Creek (07103990 (lower_CoCr)) generally were smaller than changes in the upstream reaches due to the increasingly common incidence of shale bedrock. Historically, however, changes in channel morphology in regions of bedrock outcroppings also have been substantial. Streamflow can slowly erode bedrock along fractures, at times developing subsurface channels capable of conveying most if not all streamflow during periods of low streamflow. Over time and during selected periods of high streamflow, the undermined shale is subsequently removed in small to large sheets in relatively short periods of time (Jim Bruce, U.S. Geological Survey, oral commun., 2001). Between October 1999 and October 2005, bank erosion resulting in channel widening was the dominant process altering the morphology of this reach. Channel degradation ranged from 0.28 to $0.79 \mathrm{ft}$ as a result of downcutting, and cross-sectional sediment areas decreased 31.4 to $225 \mathrm{ft}^{2}$ due to bank erosion. Slope change was negligible, 0.00001, as downcutting was not a major process in this reach. Sediment volume decreased 24,100 $\mathrm{ft}^{3}$ (table 12) between October 1999 and October 2005 as a result of bank erosion. Based on the probable range in bulk density of sand and gravel deposits and the net change in sediment volume, approximately 723 to 1,200 tons (table 12) has been removed from this reach. 

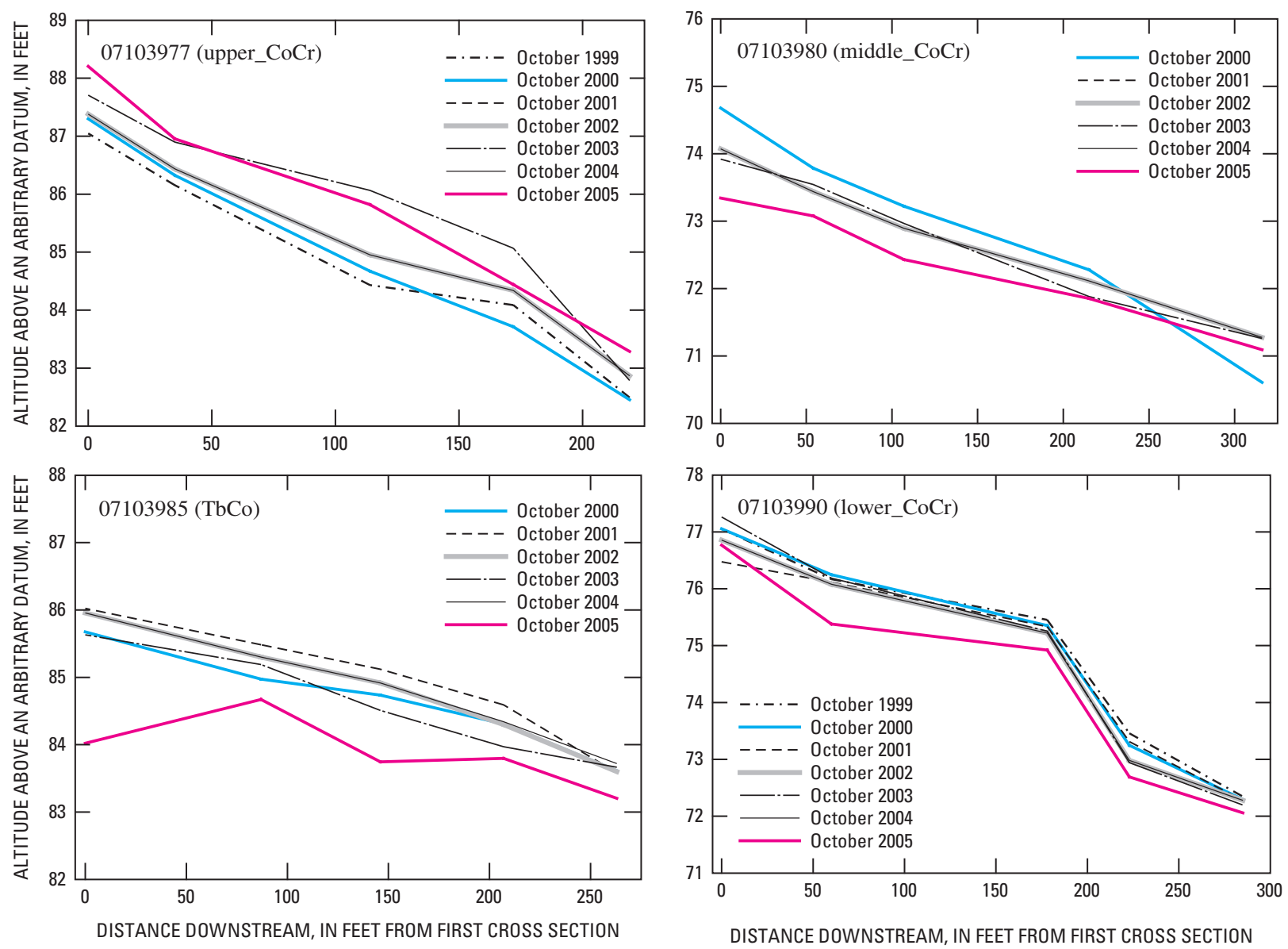

Figure 27. Change in minimum streambed altitude at cross sections along selected reaches of Cottonwood Creek near sites 07103977 (upper_CoCr), 07103980 (middle_CoCr), 07103985 (TbCo), and 07103990 (lower_CoCr), October 1999 through October 2005. 
Table 11. Change in minimum bed altitude, cross-section sediment area, and estimated mass of sediment eroded or deposited at selected cross sections in the Fountain and Monument Creek watersheds, 1999 through 2005.

[ID, identifier; ft, feet; $\mathrm{ft}^{2}$, square feet; $\mathrm{lb} / \mathrm{ft}^{3}$, pounds per cubic foot]

\begin{tabular}{|c|c|c|c|c|c|}
\hline \multirow{3}{*}{ Site number ${ }^{1}$} & \multirow{3}{*}{$\begin{array}{c}\text { Cross- } \\
\text { section } \\
\text { ID }\end{array}$} & \multirow{3}{*}{$\begin{array}{l}\text { Change } \\
\text { in minimum } \\
\text { bed altitude } \\
\text { (ft) }\end{array}$} & \multirow{3}{*}{$\begin{array}{c}\text { Change in } \\
\text { cross-section } \\
\text { sediment area } \\
\left(\mathrm{ft}^{2}\right)\end{array}$} & \multirow{2}{*}{\multicolumn{2}{|c|}{$\begin{array}{c}\text { Mass of sediments } \\
\text { eroded (-) or deposited, } \\
\text { in tons } \\
\text { Bulk density, } \\
\text { in lb/ft }{ }^{3}\end{array}$}} \\
\hline & & & & & \\
\hline & & & & 60 & 100 \\
\hline \multicolumn{6}{|c|}{ Main stem } \\
\hline \multirow{3}{*}{07103700 (FoCr_Manitou) } & $8-7$ & .86 & 7.33 & .22 & .36 \\
\hline & $6-5$ & .73 & 18.8 & .56 & .94 \\
\hline & $4-3$ & .09 & 10.0 & .30 & .50 \\
\hline \multirow{3}{*}{07103970 (MoCr_Woodmen) } & $2-5$ & .09 & 41.8 & 1.25 & 2.09 \\
\hline & $2-3$ & .25 & -39.9 & -1.20 & -1.99 \\
\hline & $2-1$ & .66 & 68.6 & 2.06 & 3.43 \\
\hline \multirow[t]{2}{*}{07104000 (MoCr_Pikeview) } & a & -.58 & -60.3 & -1.81 & -3.02 \\
\hline & $\mathrm{b}$ & -1.67 & -55.1 & -1.65 & -2.76 \\
\hline 07104905 (MoCr_Bijou) & & -.76 & -52.6 & -1.63 & -2.63 \\
\hline 07105530 (MoCr_Janitell) & & -1.28 & -24.0 & -.72 & -1.20 \\
\hline
\end{tabular}


Table 11. Change in minimum bed altitude, cross-section sediment area, and estimated mass of sediment eroded or deposited at selected cross sections in the Fountain and Monument Creek watersheds, 1999 through 2005. —Continued

[ID, identifier; ft, feet; $\mathrm{ft}^{2}$, square feet; $\mathrm{lb} / \mathrm{ft}^{3}$, pounds per cubic foot]

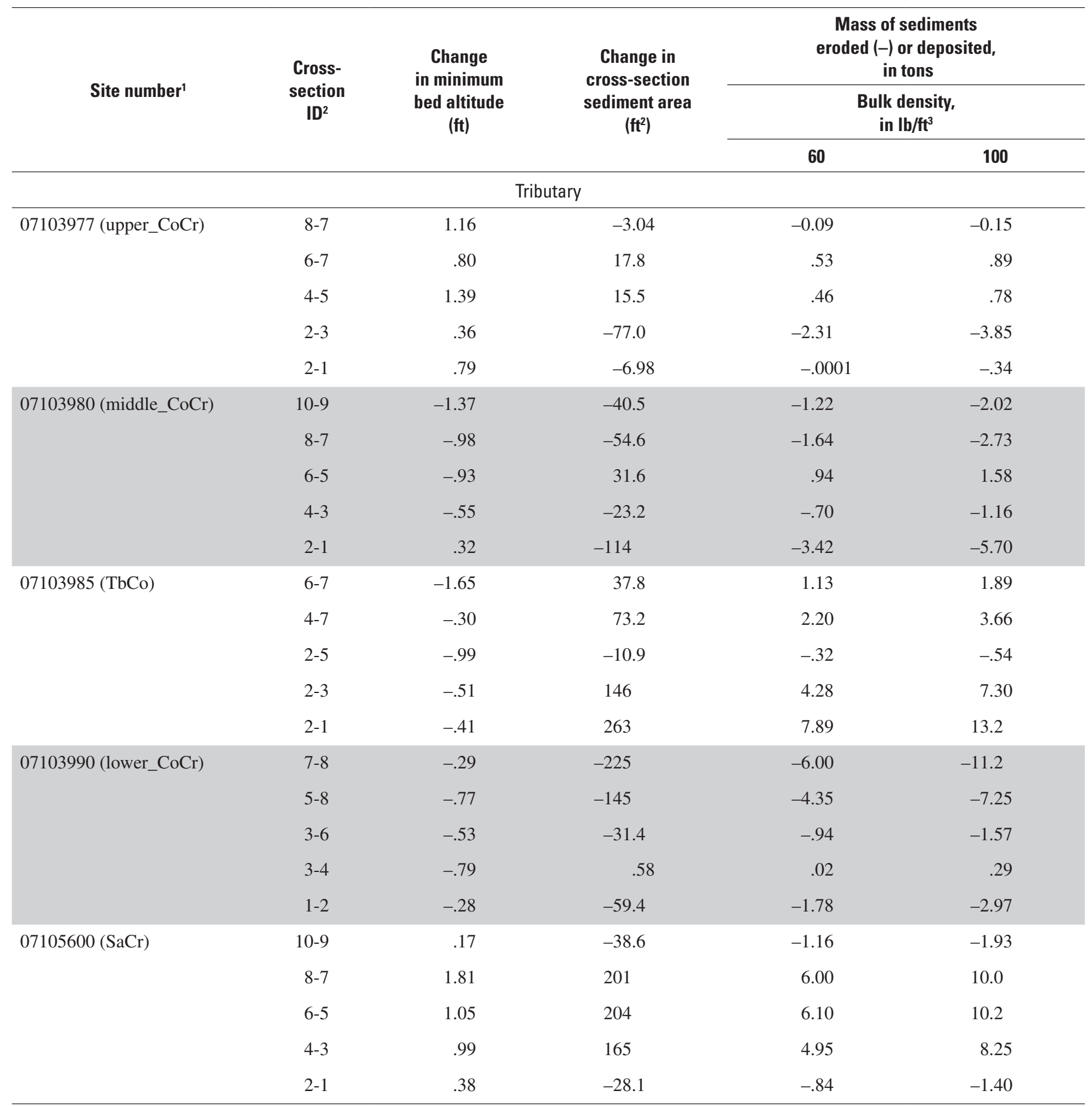

${ }^{1}$ See figure 1.

${ }^{2}$ Colorado Springs City Engineering. 

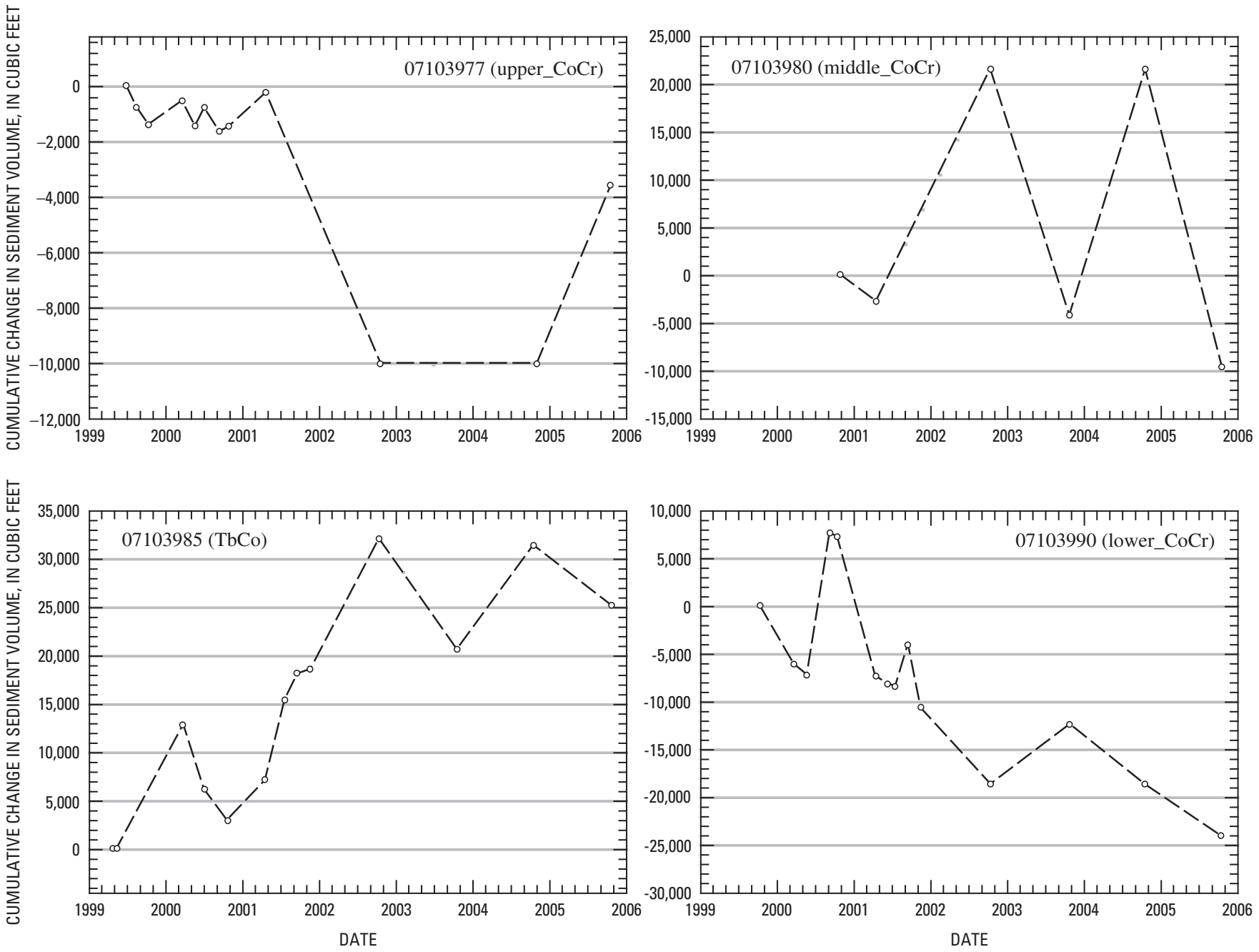

Figure 28. Cumulative change in volume of sediments of selected reaches of Cottonwood Creek near sites 07103977 (upper_CoCr), 07103980 (middle_CoCr), 07103985 (TbCo), and 07103990 (lower_CoCr), 1999 through 2005.

\section{Monument Creek}

Bed material of Monument Creek at site 07103970 (MoCr_Woodmen) is primarily sand and gravel (table 9). Surveys of cross sections along this reach since the 1999 flood have documented episodes of channel degradation and aggradation. Channel geometry as defined by the most recent series of cross-section surveys, October 2005, indicates that banks are generally stable and little lateral movement of banks has occurred in this reach. Episodes of aggradation and degradation appear to be limited to the bed. Between October 2000 and October 2005, the upper cross sections of this surveyed reach have tended to downcut, and degradation ranged from 0.65 to $0.52 \mathrm{ft}$ (fig. 29, table 11). The down-stream cross sections of the reach have tended to infill, aggrading $0.09 \mathrm{ft}$ to $0.66 \mathrm{ft}$. Between October 2000 and October 2005, the cross-sectional sediment area in the middle cross section of the reach increased, aggrading $41.8 \mathrm{ft}^{2}$, and the cross-sectional sediment area in the most-downstream cross section increased, aggrading $68.6 \mathrm{ft}^{2}$. Cross-sectional sediment areas of the remaining three cross sections decreased, degrading 22.4 to $39.9 \mathrm{ft}^{2}$ (table 11). The slope of the reach has decreased $0.00356 \mathrm{ft} / \mathrm{ft}$ as a result of downcutting in the upstream sections of the reach, and sediment volume has decreased 4,800 $\mathrm{ft}^{3}$ (fig. 30, table 12). Based on the probable range in bulk density of sand and gravel deposits and the net change in sediment volume, approximately 145 to 242 tons (table 12) has been removed from this reach.

Cross-section surveys near site 07104000 (MoCr_Pikeview) (07104000a and 07104000b) document gradual downcutting of the channel. At the upstream cross section, 07104000a, changes in channel cross section varied from one survey to the next; degradation ranged from 0.1 to $0.4 \mathrm{ft}$, and aggradation ranged from 0.1 to $0.5 \mathrm{ft}$. Between July 2003 and July 2006, maximum channel degradation was $1.1 \mathrm{ft}$. 
Table 12. Estimated mass of sediment eroded or deposited from selected reaches of Fountain, Monument, Cottonwood, and Sand Creeks, 1999 through 2005.

[ $\mathrm{ft}^{3}$, cubic foot; $\mathrm{lb}$, pound; $\mathrm{lb} / \mathrm{ft}^{3}$, pound per cubic foot]

\begin{tabular}{|c|c|c|c|c|c|}
\hline \multirow{3}{*}{$\begin{array}{l}\text { Site number and } \\
\text { abbreviation }\end{array}$} & \multirow{3}{*}{$\begin{array}{c}\text { Net change in } \\
\text { sediment volume } \\
\left(\mathrm{ft}^{3}\right)\end{array}$} & \multirow{2}{*}{\multicolumn{2}{|c|}{$\begin{array}{c}\begin{array}{c}\text { Mass of material eroded (-) or deposited } \\
\text { (Ib) }\end{array} \\
\text { Bulk density } \\
\end{array}$}} & \multirow{2}{*}{\multicolumn{2}{|c|}{$\begin{array}{c}\begin{array}{c}\text { Mass of material eroded (-) or deposited } \\
\text { (tons) }\end{array} \\
\text { Bulk density } \\
\end{array}$}} \\
\hline & & & & & \\
\hline & & $60 \mathrm{lb} / \mathrm{ft}^{3}$ & $100 \mathrm{lb} / \mathrm{ft}^{3}$ & $60 \mathrm{lb} / \mathrm{ft}^{3}$ & $100 \mathrm{lb} / \mathrm{tt}^{3}$ \\
\hline 07103700,FoCr_Manitou & 2,200 & 130,000 & 216,000 & 64.9 & 108 \\
\hline 07103970, MoCr_Woodmen & $-4,800$ & $-291,000$ & $-485,000$ & -145 & -242 \\
\hline 07103977, upper_CoCr & $-2,200$ & $-131,000$ & $-219,000$ & -65.6 & -109 \\
\hline 07103980, middle_CoCr & $-9,700$ & $-581,000$ & $-968,000$ & -290 & -480 \\
\hline 07103985, ТbСo & 22,200 & $1,340,000$ & $2,230,000$ & 670 & 1,100 \\
\hline 07103990, lower_CoCr & $-24,100$ & $-1,450,000$ & $-2,410,000$ & -723 & $-1,200$ \\
\hline 07104000, MoCr_Pikeview & $-3,270,000$ & $-19,600,000$ & $-32,600,000$ & $-9,800$ & $-16,300$ \\
\hline 07105600, $\mathrm{SaCr}$ & 112,000 & $6,710,000$ & $11,200,000$ & 3,360 & 5,600 \\
\hline 07105800, FoCr_Security & $-124,000$ & $-7,460,000$ & $-12,000,000$ & $-3,730$ & $-6,210$ \\
\hline
\end{tabular}

Subsequent channel infilling reduced the net downcutting to $0.58 \mathrm{ft}$ (table 11). In addition to the channel degradation, the cross-sectional sediment area decreased as channel downcutting along the entire cross section exceeded infilling. From July 2003 through July 2006, the cross-sectional sediment area decreased by $60.3 \mathrm{ft}^{2}$, an average of about $20 \mathrm{ft}^{2}$ per year, as the bed altitude was lowered. Based on the range in bulk density of sand and gravel samples, an estimated 1.81 to 3.02 tons of bed sediments was removed from the cross section during the period July 2003 through July 2006 (table 11).

At downstream site $07104000 \mathrm{~b}$, variations in channel morphology between one cross section and the next were larger than variations at upstream site 07104000a; channel degradation ranged from 0.0 to $2.25 \mathrm{ft}$, and channel aggradation varied from 0.0 to $1.3 \mathrm{ft}$. The cross-sectional sediment area at site $07104000 \mathrm{~b}$ has decreased by $55.1 \mathrm{ft}^{2}$ (table 11) as a result of downcutting between July 2003 and July 2006, an average of about $18 \mathrm{ft}^{2}$ per year. Based on the range in bulk density of sand and gravel samples, an estimated 1.65 to 2.76 tons (table 11 ) of bed sediments has been removed from the cross section during the period July 2003 through July 2006.

If net change in cross-sectional sediment area along the 1.1-mi-long reach between site 07104000a and 07104000b is similar to changes in cross-section area at sites 07104000a and $07104000 \mathrm{~b}$, then about $3,270,000 \mathrm{ft}^{3}$ of sand and gravel has been removed and transported downstream. This is an average of about 1,090,000 $\mathrm{ft}^{3}$ of material per year between July 2003 and July 2006. Based on the range in bulk density, an estimated 9,800 to 16,300 tons (an average of 3,200 to 5,400 tons per year) of sand and gravel has been eroded from the bed of Monument Creek within the reach near site 07104000 (table 12).

Bed material of Monument Creek at site 07104905 (MoCr_Bijou) also is primarily sand and gravel (table 9). Surveys of cross sections since 2003 have documented episodes of channel downcutting and infilling. Channel downcutting has ranged from 0.04 to $1.2 \mathrm{ft}$, and channel infilling has ranged from 0.16 to $1.3 \mathrm{ft}$. As of July 2006, the channel has degraded about $0.76 \mathrm{ft}$, and the cross-sectional sediment area has decreased $52.6 \mathrm{ft}^{2}$ (table 11). Based on the range in bulk density of sand and gravel samples, an estimated 1.63 to 2.63 tons (table 11) of bed sediments has been removed from the cross section during the period July 2003 through July 2006, an average of 0.5 to 0.9 ton per year.

\section{Fountain Creek}

Bed and bank material of Fountain Creek at sites 07103700 (FoCr_Manitou), 07105530 (FoCr_Janitell), and 07105800 (FoCr_Security) consists primarily of sand and gravel (table 9). Surveys of cross sections at these sites since 1999 have documented episodes of channel degradation and aggradation.

Cross-section surveys between October 1999 and October 2005 at site 07103700 (FoCr_Manitou) indicate that the channel has degraded $0.86 \mathrm{ft}$ at the most-upstream cross section due to downcutting, and the channel has aggraded 0.09 to $0.86 \mathrm{ft}$ (fig. 31 , table 11) at cross sections downstream due to infilling. Cross-section area decreased $20.2 \mathrm{ft}^{2}$ at the most upstream cross section and increased 6.04 to $18.8 \mathrm{ft}^{2}$ (table 11) at the cross sections downstream. The slope of the channel decreased 0.00685 , and the sediment volume increased 


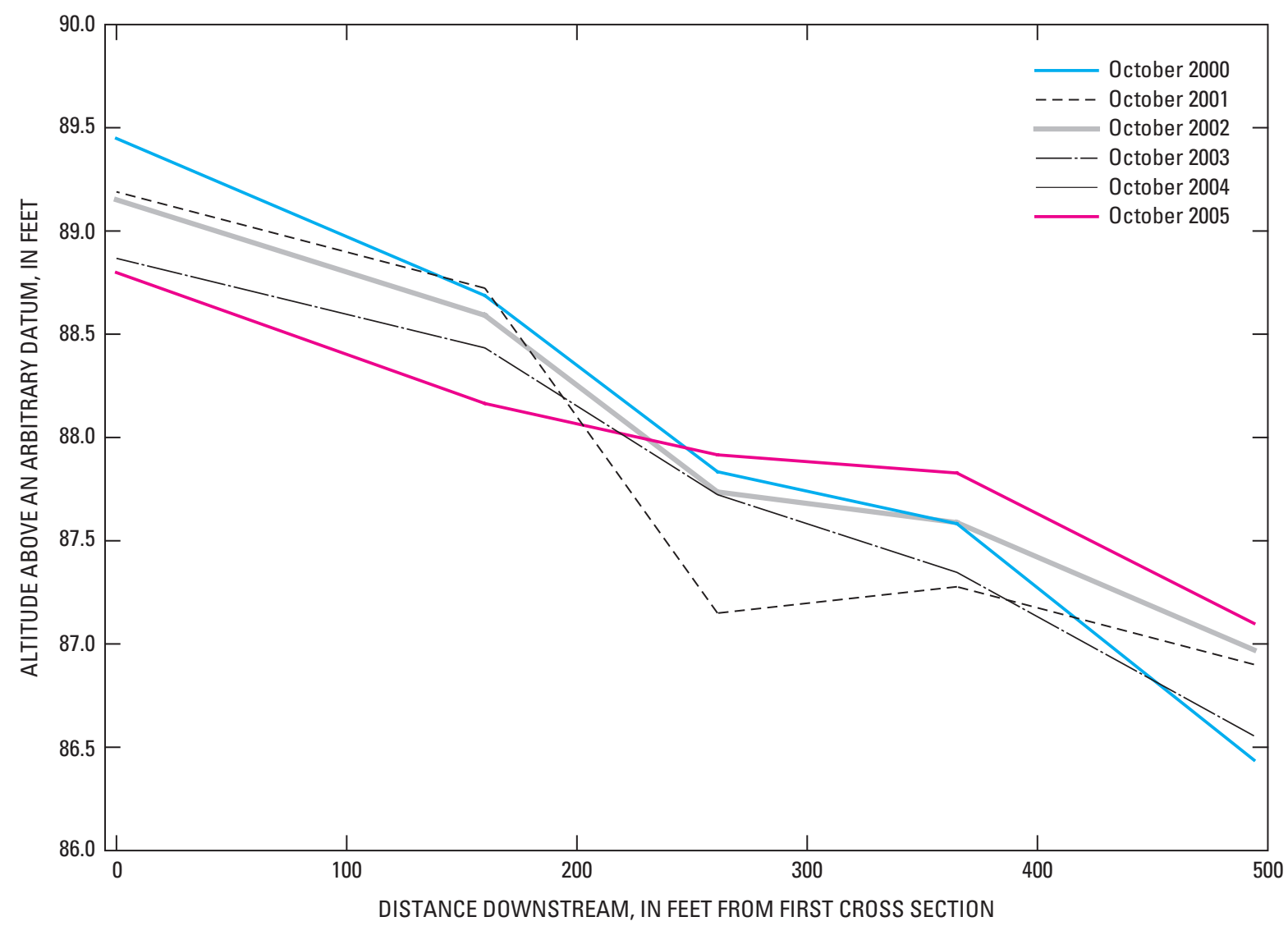

Figure 29. Change in minimum streambed altitude at cross sections along a reach of Monument Creek near site 07103970 (MoCr_Woodmen), October 2000 through October 2005.

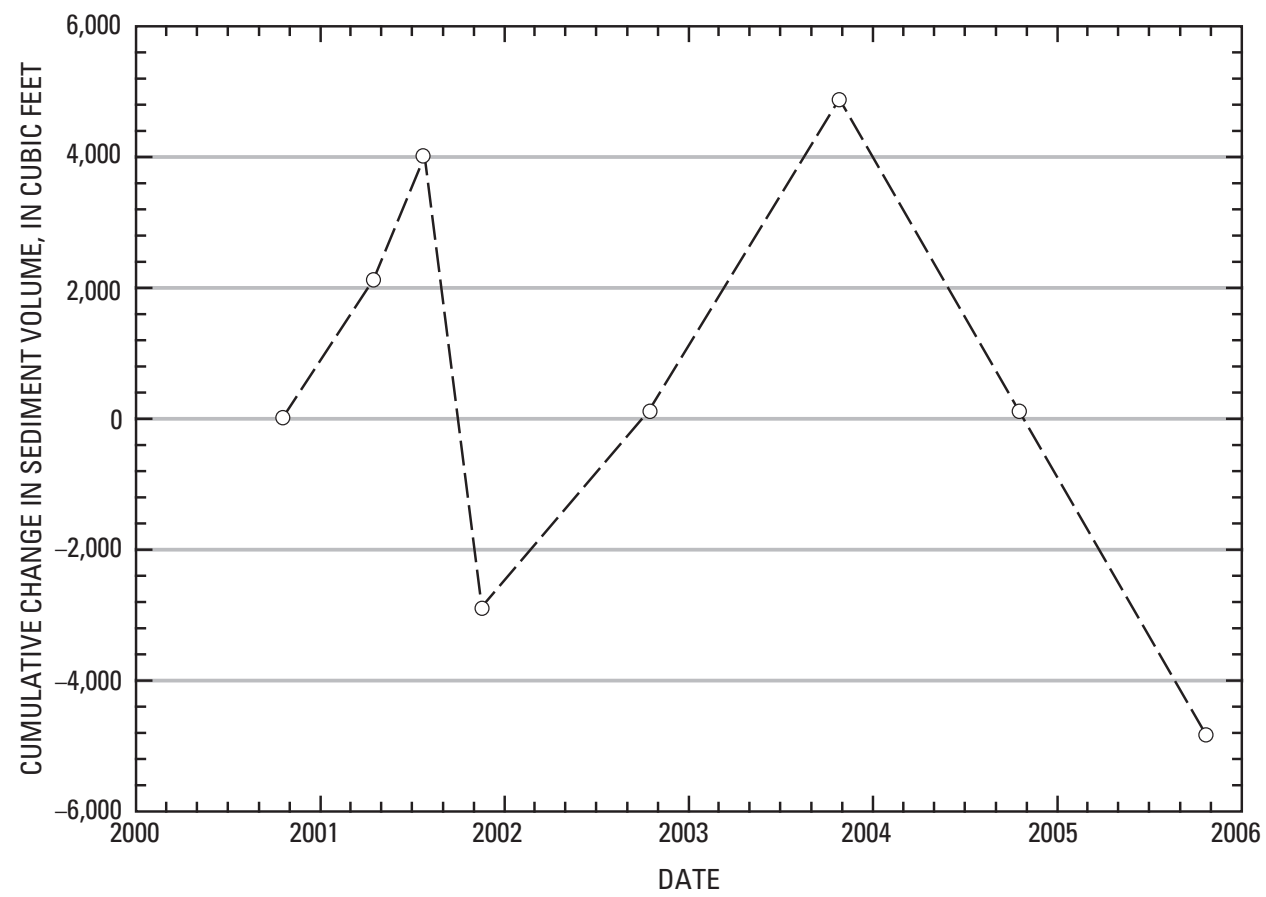

Figure 30. Cumulative change in volume of sediments of a reach of Monument Creek near site 07103970 (MoCr_Woodmen), 2000 through 2005. 

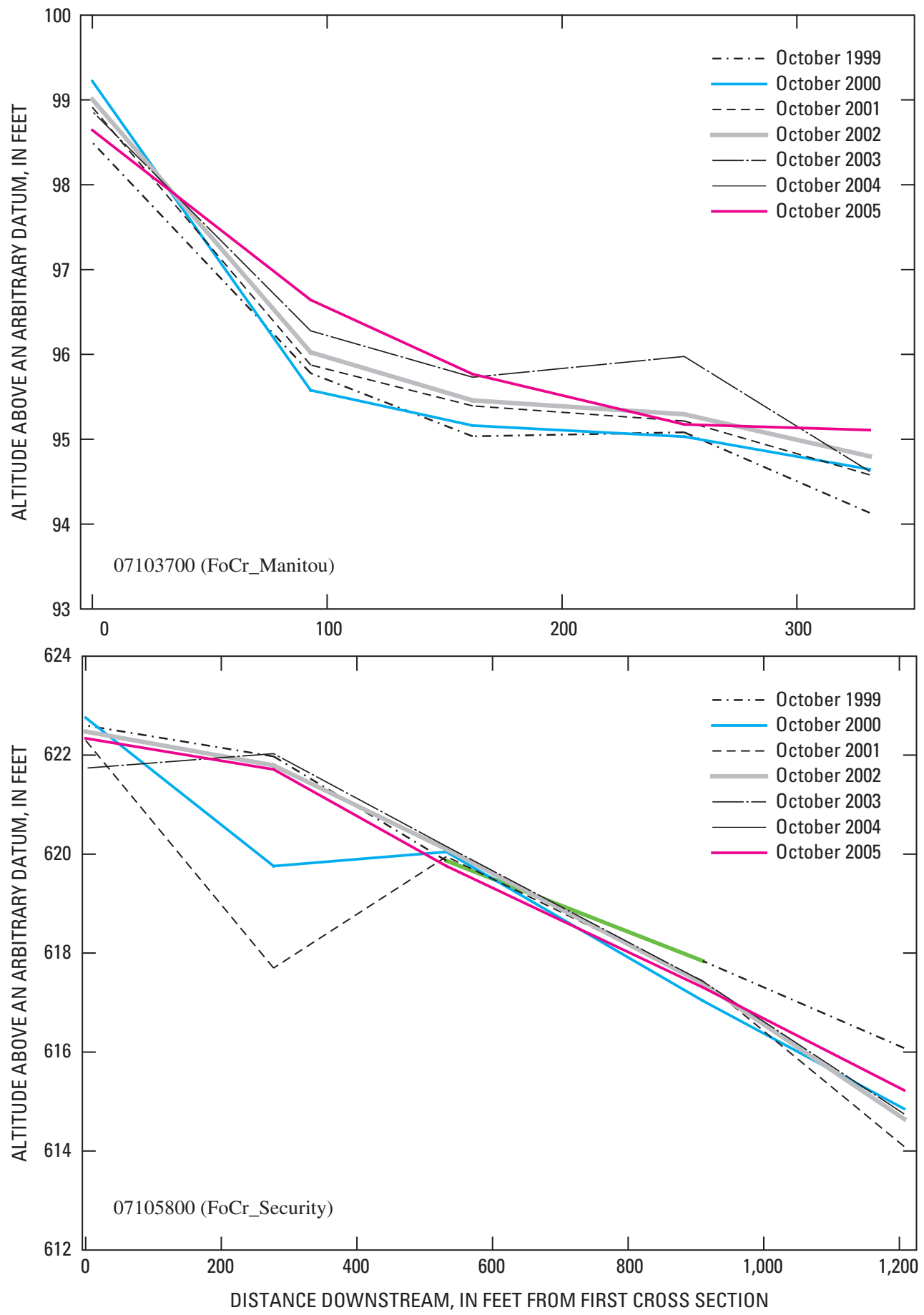

Figure 31. Change in minimum streambed altitude at cross sections along selected reaches of Fountain Creek near sites 07103700 (FoCr_Manitou) and 07105800 (FoCr_Security), October 1999 through October 2005. 

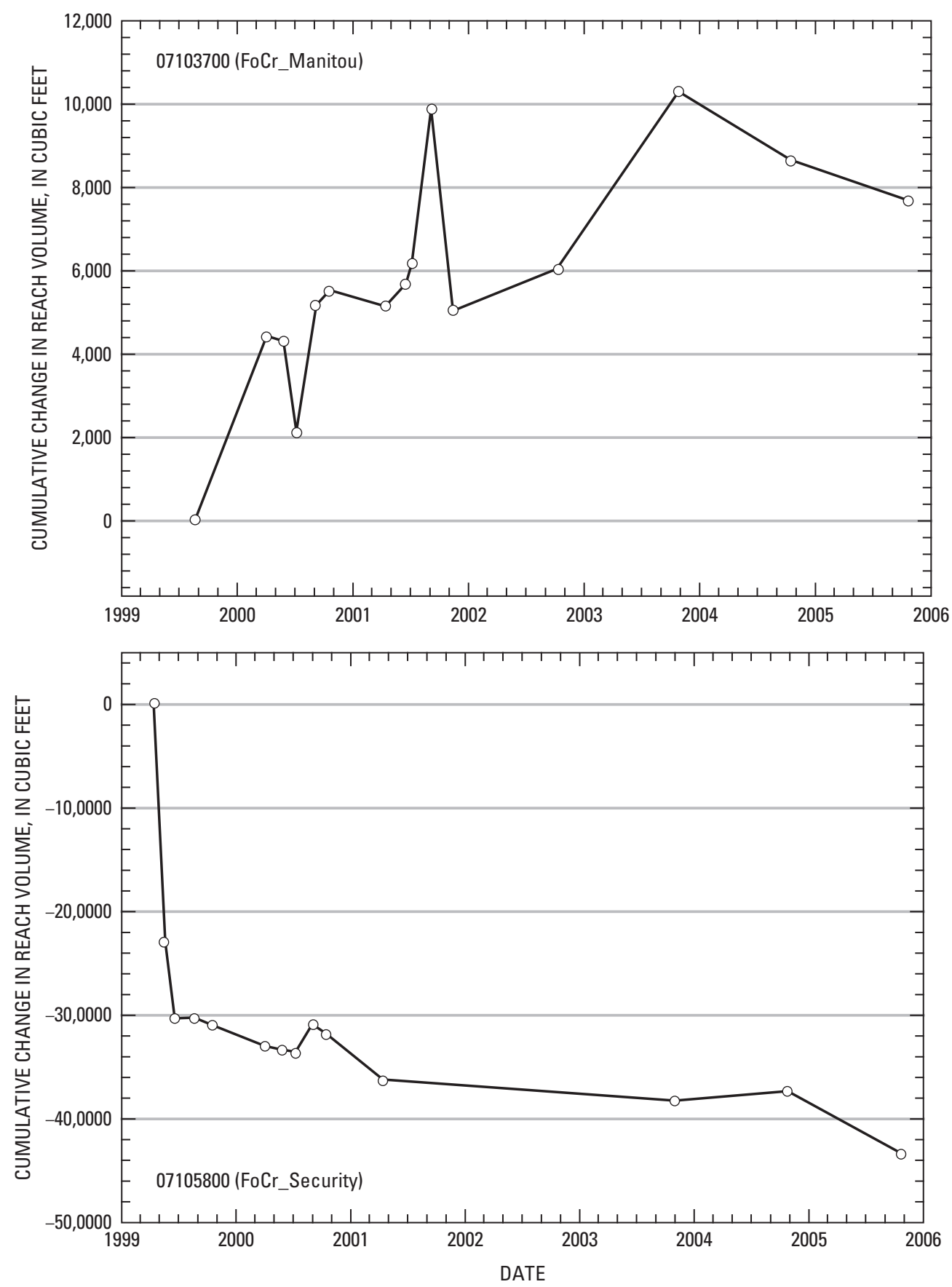

Figure 32. Cumulative change in volume of sediments of selected reaches of Fountain Creek near site 07103700 (FoCr_Manitou) and 07105800 (FoCr_Security), 1999 through 2005. 
2,200 $\mathrm{ft}^{3}$ (fig. 32, table 12). Based on the probable range in bulk density of sand and gravel deposits and the net change in reach volume, 64.9 to 108 tons (table 12) has been deposited in this reach.

Surveys of the cross section at site 07105530

(FoCr_Janitell) between July 2003 and July 2006 indicate downcutting as the dominant channel-forming process. Channel degradation ranged from 0.2 to $0.7 \mathrm{ft}$, and channel aggradation ranged from 0.1 to $0.25 \mathrm{ft}$. Between July 2003 and July 2006, net channel downcutting was $1.28 \mathrm{ft}$. Between July 2003 and July 2006, cross-section area decreased $24.0 \mathrm{ft}$ (table 11) as a result of downcutting. Based on the probable range in bulk density of sand and gravel deposits and the net change in cross-section area, approximately 0.72 to 1.2 tons (table 11) has been eroded from this cross section as a result of downcutting.

Cross-section surveys between October 1999 and October 2005 at site 07105800 (FoCr_Security) indicate downcutting as the dominant process at the three upstream cross sections and downcutting and channel widening as the dominant process at the two most downstream cross sections. Degradation at cross sections ranged from 0.11 to $0.85 \mathrm{ft}$ (table 11). Between October 1999 and October 2005, net change in cross-section area ranged from 4.84 to $-191 \mathrm{ft}^{2}$ (table 11). Estimates of the net mass of material removed from the channel between October 1999 and October 2005 ranged from about 3,730 to 6,210 tons (table 12).

To evaluate the effects of wastewater treatment-plant effluent discharges on channel morphology, the MannWhitney test was used to evaluate changes in normal flow and particle-size distribution of bed material between the upstream site, 07105500 (FoCr_Nevada), and the downstream sites, 07105530 (FoCr_Janitell) and 07105800 (FoCr_Security), of the Las Vegas Street Wastewater Treatment Plant. The Mann-Whitney test indicated a significant increase in median normal flow between site 07105500 (FoCr_Nevada) $\left(34 \mathrm{ft}^{3} / \mathrm{s}\right.$ ) and site 07105530 (FoCr_Janitell) $\left(88 \mathrm{ft}^{3} / \mathrm{s}\right)$. The MannWhitney test also indicated a significant difference in median particle size between the two sites: $4 \mathrm{~mm}$ at site 07105500 (FoCr_Nevada) and $12 \mathrm{~mm}$ at site 07105530 (FoCr_Janitell). The increased streamflow, due to wastewater treatment-plant discharges downstream from site 07105500 (FoCr_Nevada), has increased the sediment transport capacity at site 07105530 (FoCr_Janitell) (table 10) immediately downstream from the treatment plant. The increased transport capacity at site 07105530 (FoCr_Janitell) has resulted in greater transport of finer sediments and a shift in the median particle size of bed material from fine to medium gravel. The increase in transport capacity at site 07105530 (FoCr_Janitell) during normal flow appears to be limited to an undefined reach downstream from site 07105530 (FoCr_Janitell) and upstream from site 07105800 (FoCr_Security). This increase is because median particle sizes of bed material at site 07105500 (FoCr_Nevada) and site 07105800 (FoCr_Security) both equal $4 \mathrm{~mm}$, and the transport capacity based on the Shields equation at site 07105800 (FoCr_Security) is less than the transport competence at site 07105500 (FoCr_Nevada) (table 10).

\section{Sand Creek}

Channel morphology of Sand Creek (07105600) (SaCr) has only been monitored since October 2003. Cross-section surveys indicate channel infilling as the dominant process, with the channel aggrading 0.17 to $1.81 \mathrm{ft}$ (fig. 33, table 11). Changes in cross-sectional sediment area ranged from $-38.6 \mathrm{ft}^{2}$ to $-28.1 \mathrm{ft}^{2}$ at the cross sections at the ends of the reach, and $165 \mathrm{ft}^{2}$ to $204 \mathrm{ft}^{2}$ at the inner three cross sections. The slope of the channel has decreased 0.00025, and the sediment volume increased 112,000 $\mathrm{ft}^{3}$ (table 12). Based on the probable range in bulk density of sand and gravel deposits and the net change in sediment volume, 3,360 to 5,600 tons (table 12) has been deposited in this reach.

\section{Summary}

In 1998, the U.S. Geological Survey, in cooperation with Colorado Springs City Engineering, began a study of the Fountain and Monument Creek watersheds to characterize water quality and suspended-sediment conditions in the watershed for different flow regimes, with an emphasis on characterizing water quality during storm runoff. Waterquality and suspended-sediment data collected from 1981 through 2006 were used in the study. Water-quality data were collected at 11 sites between 1981 and 2001, and 14 tributary sites were added in 2003. Stream-water and sediment-quality samples were collected by the U.S. Geological Survey in the Fountain and Monument Creek watersheds from 1981 through 2006 to evaluate the effects of stormflow. The mean annual precipitation from 1981 through 2001 was 18.5 inches. The mean annual precipitation for the period 2001 through 2006 decreased to 13.5 inches, primarily due to the 2002 drought conditions; but even when 2002 was removed from the calculation of the mean, the Colorado Springs area received on average 14.5 inches of precipitation during the most recent period, similar to the recorded mean precipitation from 1949 through 1980. Between 1998 and 2006, the annual precipitation ranged from 7.8 inches in 2002 to 27.6 inches in 1999 , which represent the minimum and the maximum annual precipitation for the 52-year period of record.

Stormflow concentrations from 1998 through 2006 were compared to Colorado acute instream standards and, with the exception of a few isolated cases, did not exceed water-quality standards for inorganic constituents that were analyzed. In many cases water quality varied according to flow regime. The largest specific-conductance values occurred during base flow and, as a result of dilution, were smaller during stormflow. The largest increases in specific conductance occurred during base flow and normal flow between Fountain Creek sites 07103700 (FoCr_Manitou) and 07103707 (FoCr_8th), upstream from 


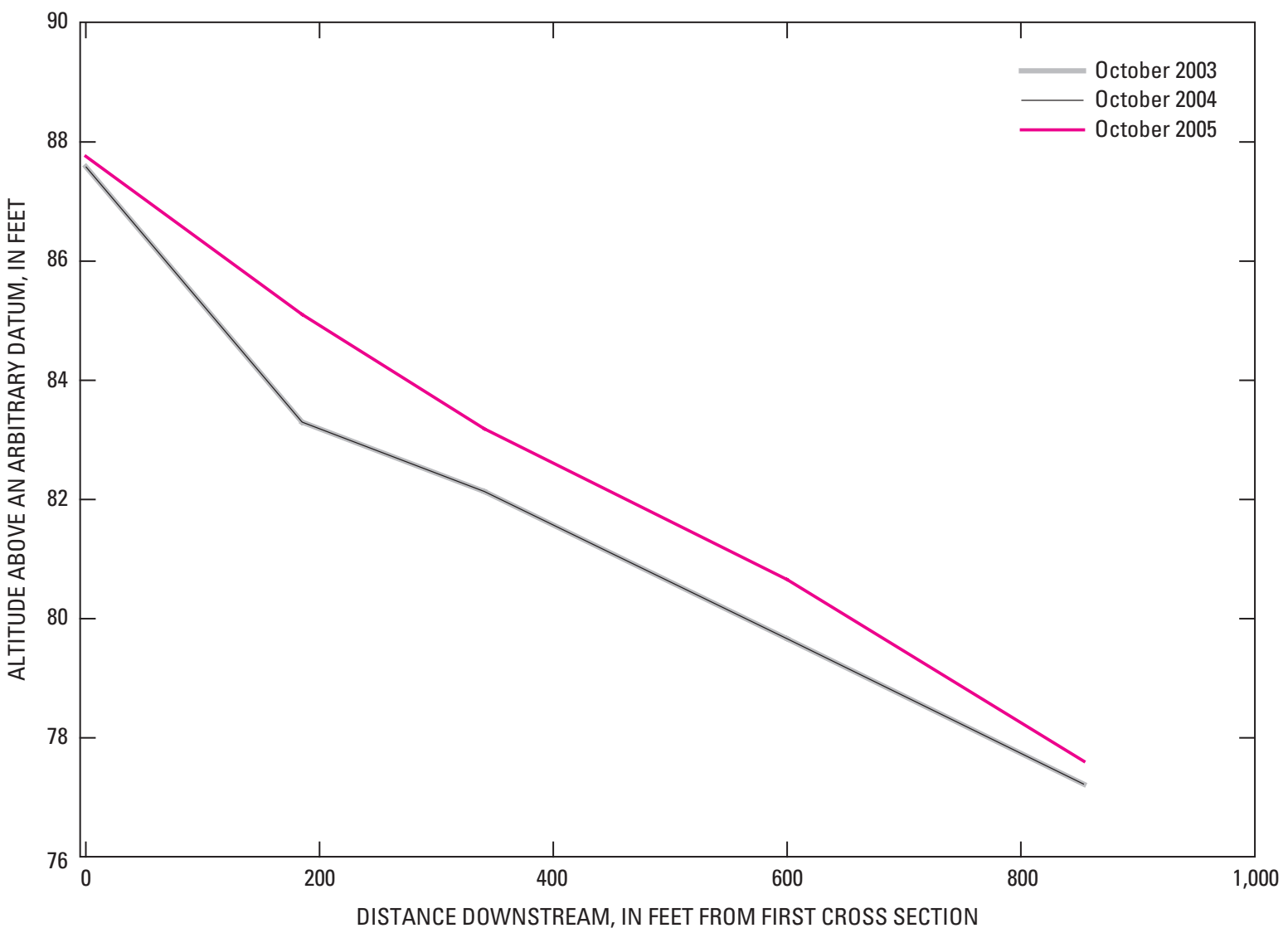

Figure 33. Change in minimum streambed altitude at cross sections along a reach of Sand Creek near site 07105600 (SaCr), October 2003 through October 2005.

the confluence with Monument Creek, which indicates a source of relatively large dissolved solids. Spatially, specific conductance tends to increase in a downstream direction. Specific conductance in Monument Creek and the tributaries draining to it ranged from less than 100 to more than 2,000 $\mu \mathrm{S} / \mathrm{cm}$, during base-flow and normal-flow conditions. Median specific-conductance concentrations generally ranged from 400 to $700 \mu \mathrm{S} / \mathrm{cm}$.

Concentrations of biochemical oxygen demand measured over a 5-day period $\left(\mathrm{BOD}_{5}\right)$ at all main-stem sites during 1998 through 2006 generally were larger during stormflow than during base flow and normal flow. Median $\mathrm{BOD}_{5}$ concentrations during stormflow ranged from 1.0 to 10.3 milligrams per liter $(\mathrm{mg} / \mathrm{L})$ compared with a range of 1.0 to $5.9 \mathrm{mg} / \mathrm{L}$ during base flow. Fecal coliform bacteria concentrations, during the period 1998 through 2006, were highly variable, generally ranging by more than a factor of 10 between flow regimes at each site. Fecal coliform concentrations tended to be largest during stormflow and smallest during base flow. Generally, median fecal coliform concentrations on Monument Creek along the main-stem were larger than 200 colonies per 100 milliliters $(\mathrm{col} / 100 \mathrm{~mL})$ during periods of normal flow and stormflow. The smallest concentrations of $E$. coli were detected during periods of base flow and were largest during periods of stormflow. Median E. coli concentrations at main-stem sites during base flow were less than $100 \mathrm{col} / 100 \mathrm{~mL}$, whereas median concentrations of $E$. coli during normal and stormflow conditions were much larger, ranging between 80 and 660 $\mathrm{col} / 100 \mathrm{~mL}$ during normal-flow conditions and 1,300 to $17,000 \mathrm{col} / 100 \mathrm{~mL}$ during stormflow conditions.

Elevated concentrations of nitrite plus nitrate were measured at two sites on Cottonwood Creek, a tributary to Monument Creek: 07103985 (TbCo) and 07103990 (lower_CoCr). During base-flow and normal-flow conditions, the median concentrations of nitrite plus nitrate ranged from 5.1 to $6.1 \mathrm{mg} / \mathrm{L}$ and were 4 to 7 times larger than concentrations at the nearest upstream site on Monument Creek, site 07103970. Median concentrations of total phosphorus in Fountain Creek upstream from the Monument Creek confluence tended to be larger during stormflow and smaller during base-flow and normal-flow conditions. Median total phosphorus concentrations at sites 07103970 (MoCr_Woodmen) and 07104905 (MoCr_Bijou) during stormflow were 2.4 to 5.6 times larger than concentrations during base-flow and normal-flow conditions, respectively. 
Between sites 07105500 (FoCr_Nevada) and 07105530 (FoCr_Janitell), during 1998 through 2006, median concentrations of dissolved nitrite plus nitrate, dissolved ammonia, and total phosphorus increased significantly downstream from the Las Vegas Street Wastewater Treatment Plant effluent outfall. The upstream to downstream increase was most pronounced during base-flow and normal-flow conditions but also was evident during stormflow conditions for all nutrients analyzed.

Large differences in median base-flow concentration in several trace elements were apparent between Fountain Creek sites 07103700 (FoCr_Manitou) and 07103707 (FoCr_8th), upstream from the confluence with Monument Creek. Concentrations of dissolved and total copper, total manganese, total nickel, dissolved and total selenium, and dissolved and total zinc ranged from 3 to 27 times larger at site 07103707 (FoCr_8th) than at site 07103700 (FoCr_Manitou) during base flow, indicating a large source of trace elements between these two sites. The likely source area is Gold Hill Mesa, a former tailings pile for a gold refinery located just upstream from the confluence with Monument Creek, and upstream from site 07103707 (FoCr_8th). Median total selenium concentrations during base flow and normal flow increased from 1.0 to 6.8 micrograms per liter $(\mu \mathrm{g} / \mathrm{L})$ and 0.50 to $4.0 \mu \mathrm{g} / \mathrm{L}$, respectively, between sites 07103700 (FoCr_Manitou) and 07103707 (FoCr_8th). Farther downstream in Fountain Creek, stormflow concentrations for total copper, lead, manganese, nickel, and zinc were larger at site 07105800 (FoCr_Security) than at site 07105530 (FoCr_Janitell), compared with other main-stem sites, and indicate a relatively large source of these metals between the two sites. Similar patterns for total copper, lead, nickel, and zinc were observed during the previous permit period, 1998 through 2002, indicating that the source area is still contributing trace metals downstream from site 07105530 (FoCr_Janitell), although in some cases median stormflow concentrations have declined slightly since 1998 .

Instantaneous nutrient loads varied considerably from site to site during the period 1998 through 2006, and stormflow loads generally were considerably larger than during base-flow and normal-flow conditions. Loads increased downstream from the Fountain-Monument Creek confluence because of the combined flows from both creeks, but also, in some cases, because nutrient concentrations were larger in lower Fountain Creek than in upper Fountain or Monument Creeks. Large increases in nutrient loading were particularly noticeable downstream from the Nevada Street Wastewater Treatment Plant at site 07105530 (FoCr_Janitell). Nutrient loads increased between sites 07105500 (FoCr_Nevada) and 07105530 (FoCr_Janitell), on average, more than 350 percent during stormflow conditions.

Loads of most dissolved and total trace elements increased between sites 07103970 (MoCr_Woodmen) and 07104905 (MoCr_Bijou) during base-flow, normal-flow, and stormflow conditions. The load increase generally was between 2 and 4 times larger at the downstream site 07104905 (MoCr_Bijou) during base-flow and normal-flow conditions but was larger during stormflow conditions when loads increased by 1.2 to 18 times.

Suspended-sediment concentrations, discharges, and yields associated with stormflow were significantly larger than those during normal flow. Significant temporal differences in median suspended-sediment concentration, discharge, and yield at a site generally coincided with a significant increase or decrease in median streamflow.

During normal flow, the uppermost location on Monument Creek, site 07103970 (MoCr_Woodmen), had the smallest median suspended-sediment concentrations. Cottonwood Creek had the largest median suspended-sediment concentrations during normal flow. Suspended-sediment concentrations during normal flow at sites downstream from Cottonwood Creek were not significantly different from one another. Suspended-sediment concentrations during stormflow generally increased in a downstream order for main-stem sites on Fountain and Monument Creeks. The largest suspendedsediment concentrations during stormflow were measured on Cottonwood Creek.

Suspended-sediment discharge during normal flow varied by site, generally increasing from upstream to downstream as streamflow increased. Suspended-sediment discharge of Cottonwood Creek at site 07103990 (lower_CoCr) ranged from 3 to 10 tons per day (tons/d) and represented a significant fraction of the suspended-sediment discharge of Monument Creek at site 07104905 (MoCr_Bijou) during normal flow. Suspended-sediment discharge ranged from 0.5 to 10 tons/d at the most upstream site on Monument Creek (07103970, MoCr_Woodmen) and ranged from 25 to 180 tons/d at the most downstream site on Fountain Creek (07105800, FoCr_Security).

During stormflow, suspended-sediment discharge increased in a downstream order, ranging from 20 to 250 tons/d at the most upstream site (07103970, MoCr_Woodmen) and ranging from 700 to 4,000 tons/d at the most downstream site (07105800, FoCr_Security). Suspended-sediment discharge during stormflow did not always increase as drainage area increased. Suspended-sediment discharge at Cottonwood Creek, with a drainage area of about $18.7 \mathrm{mi}^{2}$, was almost 2 times larger than suspended-sediment discharge at site 07103970 (MoCr_Woodmen), with a drainage area of about $180 \mathrm{mi}^{2}$. Suspended-sediment discharge of Cottonwood Creek during stormflow generally was larger than suspendedsediment discharge of Sand Creek.

Total cumulative daily suspended-sediment discharges increased from upstream to downstream sites and varied from year to year, largest in 1999 and smallest in 2002. Suspendedsediment discharges of Cottonwood Creek, site 07103990 (lower_CoCr), were generally larger than suspended-sediment discharges at site 07103970 (MoCr_Woodmen), despite the larger drainage area at site 07103970 . An evaluation of relative contribution of suspended-sediment discharge at site 07103990 (lower_CoCr) to downstream sites indicated that suspendedsediment discharge from 07103990 (lower_CoCr) represented 18 to 30 percent of suspended-sediment discharge at 
site 07104905 (MoCr_Bijou). Suspended-sediment discharge at site 07103970 (MoCr_Woodmen) represented 13 to 18 percent of suspended-sediment discharge at site 07104905 (MoCr_Bijou). Suspended-sediment discharge at site 07103970 (MoCr_Woodmen) and 07103990 (lower_CoCr) accounted for only about 35 to 45 percent of suspendedsediment discharge at site 07104905 (MoCr_Bijou), indicating that additional sources of suspended-sediment discharge exist between sites 07103970 (MoCr_Woodmen), 07103990 (lower_CoCr) and 07104905 (MoCr_Bijou). Suspendedsediment discharge at site 07104905 (MoCr_Bijou) generally was similar to suspended-sediment discharges at site 07105500 (FoCr_Nevada). The relative contribution of suspended-sediment discharge at site 07104905 (MoCr_Bijou) to suspended-sediment discharge at site 07105500

(FoCr_Nevada) ranged from 68 to 98 percent. Suspendedsediment discharge at site 07105500 (FoCr_Nevada) generally represented about 70 percent of suspended-sediment discharge at site 07105800 (FoCr_Security). Relative contributions of suspended-sediment discharge from site $07105600(\mathrm{SaCr})$ to site 07105800 (FoCr_Security) ranged from 23 to 37 percent.

Suspended-sediment yields provide a means for identifying source contribution areas. The smallest yields were computed at site 07103970 (MoCr_Woodmen) (drainage area of $180 \mathrm{mi}^{2}$ ). Site 07103990 (lower_CoCr) (drainage area of $18.7 \mathrm{mi}^{2}$ ) had the largest suspended-sediment yields. Suspended-sediment yields increased progressively from site 07103970 (MoCr_Woodmen) to site 07105800 (FoCr_Security) during normal flow and stormflow as drainage area increased. Suspended-sediment yields vary by more than an order of magnitude during normal flow but generally are small. Although large spatial variations in suspended-sediment yields occurred during normal flows, the suspended-sediment yields that were associated with stormflow generally were more than 10 times larger than the suspended-sediment yields that occurred during normal flow.

Instantaneous suspended-sediment concentration samples were collected at selected ungaged tributaries to better characterize the spatial variability of suspended sediment in the Fountain and Monument Creek watersheds. Suspendedsediment concentrations during normal flow and stormflow varied considerably at individual sites and spatially between sites. Sites on streams in the Colorado Piedmont and draining to Fountain and Monument Creeks from the east generally had larger suspended-sediment concentrations than sites on streams in the Colorado Piedmont and Southern Colorado Rocky Mountains physiographic regions and draining to Fountain and Monument Creeks from the west. The largest concentrations were measured in Kettle Creek, Cottonwood Creek, and Sand Creek, which drain the Colorado Piedmont from the east of Fountain and Monument Creeks, and North Rockrimmon Creek, which drains the Colorado Piedmont from the west of Monument Creek. Suspendedsediment concentrations during stormflow at sites that drain the Colorado Piedmont ranged from about 800 to about $60,000 \mathrm{mg} / \mathrm{L}$. Suspended-sediment concentrations during stormflow at sites that drain the Southern Rocky Mountains physiographic province (Bear Creek sites 07105000 and 384909104504401) ranged from about 10 to about $1,000 \mathrm{mg} / \mathrm{L}$. Suspended-sediment discharge ranged from less than 10 tons/d at sites on streams that drain to Fountain and Monument Creeks from the west and ranged from 1,000 and 10,000 tons/d at sites on streams that drain to Fountain and Monument Creeks from the east. Suspended-sediment yields varied less spatially, generally ranging from 10 to $100 \mathrm{tons} / \mathrm{d} / \mathrm{mi}^{2}$.

Analysis of the sediment transport capacity for Fountain and Monument Creeks and Kettle, Cottonwood, and Bear Creek tributaries indicated that minimum streamflows at all sites generally have the capacity to transport coarse to very coarse sands. Higher flows have the capacity to transport coarse gravel. Transport of cobble-size bed material is possible at the largest measured flows at sites 07103700 (FoCr_Manitou), 07103990 (lower_CoCr), 07105000 (upper_BeCr), and 07105500 (FoCr_Nevada). Periodic surveys of channel cross-section geometry indicate that channel downcutting is the predominant channel-forming process in the Fountain Creek watershed. Episodes of channel degradation and aggradation have occurred at most sites surveyed between 1999 and 2005. Estimates of changes in volume of sediments of surveyed reaches ranged from $-2,200 \mathrm{ft}^{3}$ at site 07103977 (upper_CoCr) to $124,000 \mathrm{ft}^{3}$ at site 07105800 (FoCr_Security). Estimated mass of eroded bed and bank material from surveyed reaches between 1999 and 2005 varied from 64.9 to 6,210 tons. Wastewater treatment-plant discharges increased streamflows and resulted in increased sediment transport capacity immediately downstream from the wastewater treatment plant. The increased sediment transport capacity has resulted in a shift in the median particle size of bed material from fine gravel upstream from the wastewater treatment plant to medium gravel immediately downstream from the wastewater treatment plant.

\section{References Cited}

Anderson, Keith E., 1973, Water well handbook: St. Louis, Missouri Water Well \& Pump Contractors Association., Inc., Scholin Brothers Printing Company.

Buchanan, T.J., and Somers, W.P., 1968, Stage measurement at gaging stations: U.S. Geological Survey Techniques of Water-Resources Investigations, book 3, chap. A7, 28 p.

Carter, R.W., and Davidian, Jacob, 1968, General procedure for gaging streams: U.S. Geological Survey Techniques of Water-Resources Investigations, book 3, chap. A6, 13 p. 
City of Colorado Springs, 1997, Municipal stormwater discharge permit, Information available on the Web, accessed May 25, 2007, at http://www.springsgov.com/Page. asp? NavID=139\&Print $=$ True

Colorado Department of Public Health and Environment, 2001a, Standards and methodologies for surface water, 5 CCR 1002-31: Colorado Department of Public Health and Environment, Water Quality Control Commission, various pagination.

Colorado Department of Public Health and Environment, 2001b, Regulation no. 32, Classifications and numeric standards for Arkansas River Basin: Colorado Department of Public Health and Environment, Water Quality Control Commission, various pagination.

Colorado Department of Public Health and Environment, 2003, Voluntary clean-up and redevelopment program, Information available on the Web, accessed May 1, 2007, at http://198.187.128.12/colorado/1pext. $d l l ? f=$ templates $\& f n=f s-$ main. $h t m \& 2.0$.

Colorado Department of Public Health and Environment, 2006, Water Quality Control Commission Regulations, Surface Water Quality Classifications and Standards, Information available on the Web, accessed May 25, 2007, at http://www.cdphe.state.co.us/regulations/wqccregs/

Crowfoot, R.M., Bruce, N.L., Unruh, J.W., Ritz, G.F., Steger, R.D., and O'Neill, G.B., 1999, Water resources data Colorado, water year 1998, Volume 1. Missouri River Basin, Arkansas River Basin, and Rio Grande Basin: U.S. Geological Survey Water-Data Report CO-98-1, 451 p.

Crowfoot, R.M., Unruh, J.W., Ritz, G.F., Steger, R.D., and O’Neill, G.B., 2000, Water resources data Colorado, water year 1999, Volume 1. Missouri River Basin, Arkansas River Basin, and Rio Grande Basin: U.S. Geological Survey Water-Data Report CO-99-1, 499 p.

Crowfoot, R.M., Unruh, J.W., Ritz, G.F., Steger, R.D., and O’Neill, G.B., 2001, Water resources data Colorado, water year 2000, Volume 1. Missouri River Basin, Arkansas River Basin, and Rio Grande Basin: U.S. Geological Survey Water-Data Report CO-00-1, 498 p.

Crowfoot, R.M., Steger, R.D., Payne, W.F., and O’Neill, G.B., 2002, Water resources data Colorado, water year 2001, Volume 1. Missouri River Basin, Arkansas River Basin, and Rio Grande Basin: U.S. Geological Survey Water-Data Report CO-01-1, 539 p.

Crowfoot, R.M., Payne, W.F., and O’Neill, G.B., 2003, Water resources data Colorado, water year 2002, Volume 1. Missouri River Basin, Arkansas River Basin, and Rio Grande Basin: U.S. Geological Survey Water-Data Report CO-02-1, 609 p.
Crowfoot, R.M., Payne, W.F., and O'Neill, G.B., 2004, Water resources data Colorado, water year 2003, Volume 1. Missouri River Basin, Arkansas River Basin, and Rio Grande Basin: U.S. Geological Survey Water-Data Report CO-03-1, 577 p.

Crowfoot, R.M., Payne, W.F., O’Neill, G.B., Boulger, R.W., and Sullivan, J.R., 2005, Water resources data Colorado, water year 2004, Volume 1. Missouri River Basin, Arkansas River Basin, and Rio Grande Basin: U.S. Geological Survey Water-Data Report CO-04-1, 379 p.

Crowfoot, R.M., Payne, W.F., O’Neill, G.B., and Boulger, R.W., 2006, Water resources data Colorado, water year 2005, Information available on the Web, accessed May 11, 2007, at http://web10capp.er.usgs.gov/adr_lookup/wdr-co05/index.jsp

Dunne, Thomas, and Leopold, L.B., 1978, Water in environmental planning: New York, W.H. Freeman and Company, 818 p.

Edelmann, Patrick, Ferguson, S.A., Stogner, R.W., Sr., August, M., Payne, W.F., and Bruce, J.F., 2002, Evaluation of water quality, suspended sediment, and stream morphology with an emphasis on effects of storm flow on Fountain and Monument Creek basins, Colorado Springs and vicinity, Colorado, 1981 through 2001: U.S. Geological Survey Water-Resources Investigations Report 2002-4104, 59 p.

Edwards, T.K., and Glysson, G.D., 1988, Field methods for measurement of fluvial sediment: U.S. Geological Survey Open-File Report 86-531, 117 p.

Elliott, J.G., Kircher, J.E., and von Guerard, Paul, 1984, Sediment transport in the lower Yampa River, northwestern Colorado: U.S. Geological Survey Water-Resources Investigations Report 84-4141, 44 p.

Environmental Systems Research Institute, Inc., 1982-2005, Arc/Info version 9.1.

Environmental Systems Research Institute, Inc., 1999-2005, Arc/Map version 9.1.

Gordon, Nancy D., McMahon, Thomas A., Finlayson, Brian L., Gippel, Christopher J., and Nathan, Rory J., 2004, Stream hydrology, an introduction for ecologists: West Sussex, John Wiley and Sons, Ltd., 429 p.

Hansen, W.R., and Crosby, E.J., 1982, Environmental geology of the Front Range urban corridor and vicinity, Colorado with a specific section on Physical properties and performance characteristics of surficial deposits and rock units in the greater Denver area by R.R. Shroba: U.S. Geological Survey Professional Paper 1230, 99 p. 
Harrelson, C.C., Rawlins, C.L., and Potyondy, J.P., 1994, Stream channel reference sites-An illustrated guide to field technique, General Technical Report RM-245: Fort Collins, Colo., U.S. Department of Agriculture, Forest Service, Rocky Mountain Forest and Range Experiment Station, $61 \mathrm{p}$.

Helsel, D.R., and Hirsch, R.M., 1992 Statistical methods in water resources: New York, Elsevier Science Publishing Company Inc., $522 \mathrm{p}$.

Horowitz, A.J., Demas, C.R., Fitzgerald, K.K., Miller, T.L., and Rickert, D.A., 1994, U.S. Geological Survey protocol for the collection and processing of surface-water samples for the subsequent determination of inorganic constituents in filtered water: U.S. Geological Survey Open-File Report 94-539, $57 \mathrm{p}$.

Karlinger, M.R., Eschner, T.R., Hadley, R.F., and Kircher, J.E., 1983, Relation of channel-width maintenance to sediment transport and river morphology_Platte River, south-central Nebraska: U.S. Geological Survey Professional Paper 1277-E, 19 p.

Kennedy, E.J., 1983, Computation of continuous records of streamflow: U.S. Geological Survey Techniques of WaterResources Investigations, book 3, chap. A13, 53 p.

Kennedy, E.J., 1984, Discharge ratings at gaging stations: U.S. Geological Survey Techniques of Water-Resources Investigations, book 3, chap. A10, 59 p.

Kennedy, E.J., 1990, Levels at streamflow gaging stations: U.S. Geological Survey Techniques of Water-Resources Investigations, book 3, chap. A19, 27 p.

Koltun, G.F., Eberle, M., Gray, J.R., Glysson, G.D., 2006, User's manual for the Graphical Constituent Loading Analysis System (GCLAS): U.S. Geological Survey Techniques and Methods 4-C1, $51 \mathrm{p}$.

Koltun, G.F., Gray, J.R., and McElhone, T.J., 1994, Users manual for DECALC, a computer program for computation of suspended-sediment discharge: U.S. Geological Survey Open-File Report 94-459, 46 p.

Larsen, L.S., 1981, Soil survey of El Paso County area, Colorado: Washington D.C., U.S. Department of Agriculture, Soil Conservation Service, $212 \mathrm{p}$.

Leopold, L.B., Wolman, M.G., and Miller, J.P., 1964, Fluvial processes in geomorphology: New York, Dover Publications, Inc., 522 p.

Meade, Robert H., 1985, Wavelike movement of bedload sediment, East Fork River, Wyoming: Environmental Geology, v. 7 , no. 4 , p. 215-225.
National Water Information System, 2007, Information available on the Web, accessed April 12, 2007, at http:// waterdata.usgs.gov/co/nwis

Pikes Peak Area Council of Governments, 2005, Fountain Creek Watershed, Impervious surface area and watershed health analysis, accessed April 8, 2007, at http://www. fountain-crk.org/Reports/impervious\%20surface\%20report. htm

Rowland, R.C., Stephens, D.W., Waddell, B., and Naftz, D.L., 2003, Selenium contamination and remediation at Stewart Lake Waterfowl Management Area and Ashley Creek, Middle Green River Basin, Utah: U.S. Geological Survey Fact Sheet 031-03, 6 p.

Schumm, S.A., 1977, The effluvial system: New York, John Wiley and Sons, 338 p.

Seiler, R.L., Skorupa, J.P., and Peltz, L.A., 1999, Areas susceptible to irrigation-induced selenium contamination of water and biota in the western United States: U.S. Geological Survey Circular 1180, 36 p.

Shelton, Theodore, 1991, Interpreting drinking water quality analysis-What do the numbers mean?: New Brunswick, N.J., Rutgers Cooperative Extension, 58 p.

Stogner, R.W., Sr., 2000, Trends in precipitation and streamflow and changes in stream morphology in the Fountain Creek watershed, Colorado, 1939-99: U.S. Geological Survey Water-Resources Investigations Report 2000-4130, $43 \mathrm{p}$.

Sylvester, M.A., Kister, L.R., and Garrett, W.B., eds., 1990, Guidelines for the collection, treatment, and analysis of water samples, U.S. Geological Survey Western Region field manual: Unpublished report on file in the Pueblo, Colo., Water Resources Discipline Office of the U.S. Geological Survey, $144 \mathrm{p}$.

The Gazette, Colorado Springs, 2006, Colorado Springs in perspective: Information available on the Web, accessed March 27, 2007, at http://www2.gazette.com/advertise/ market.html

University of Wisconsin-Extension, 1997, Polluted urban runoff-A source of concern: Information available on the Web, accessed March 12, 2007, at http://clean-water.uwex. edu/pubs/pdf/storm.urban.pdf

U.S. Census Bureau, 2007, Population Finder, Information available on the Web, accessed May 3, 2007, at http:// factfinder.census.gov/servlet/SAFFPopulation? event $=S e a r c h \& \_n a m e=e l+p a s o \& \_s t a t e=04000 U S 08 \& \_$ county $=e l+p a s o \& \_c i t y T o w n=e l+p a s o \& \_z i p=\& \_s s e=o n \& \_$ lang $=$ en $\& p c t x t=f p h$ 
U.S. Environmental Protection Agency, 1986, Ambient water quality criteria for bacteria, 1986: Washington, D.C., U.S. Environmental Protection Agency, Office of Water Regulations and Standards, EPA/440/5-84-002. Office of Water Regulations and Standards.

U.S. Environmental Protection Agency, 1992, Guidance manual for the preparation of part 1 of the NPDES permit applications for discharges from municipal separate storm sewer systems: U.S. Environmental Protection Agency, Office of Water, EPA 505/8-91-003A, various pagination.

U.S. Environmental Protection Agency, 2004, Monitoring and assessing water quality, chapter 5.11, fecal bacteria: Information available on the Web, accessed March 12, 2007, at http://www.epa.gov/OWOW/monitoring/volunteer/stream/ vms511.html

U.S. Geological Survey, 1977, National handbook of recommended methods for water-data acquisition: Reston, Va.: U.S. Geological Survey monograph, Office of Water Data Coordination, various pagination.

von Guerard, Paul, 1989a, Suspended sediment and sedimentsource areas in the Fountain Creek drainage basin upstream from Widefield, southeastern Colorado: U.S. Geological Survey Water-Resources Investigations Report 88-4136, $36 \mathrm{p}$.

von Guerard, Paul, 1989b, Sediment-transport characteristics and effects of sediment transport on benthic invertebrates in the Fountain Creek drainage basin upstream from Widefield, southeastern Colorado 1985-88: U.S. Geological Survey Water-Resources Investigations Report 88-4161, 133 p.

Wahl, K.L., and Wahl, T.L., 1995, Determining the flow of Comal Springs at new Braunfels, Texas: Texas Water 95, American Society of Civil Engineers, August 16-17, 1995, San Antonio, Texas, p. 77-86.

Wilde, F.D., Radtke, D.B., Gibs, J., and Iwatsubo, R.T., eds., 1998, National field manual for collection of water-quality data: U.S. Geological Survey Techniques of WaterResources Investigations, book 9, chap. A6, various pagination.

Wolman, M.G., 1954, A method of sampling coarse river-bed material: Transactions of the American Geophysical Union, v. 35, no. 6, p. 951-956.

Wolman, M.G., and Miller, J.P., 1960, Magnitude and frequency of forces in geomorphic process: Journal of Geology, v 68 , no. 1, p.54-74.

World Health Organization, 1996, Trace elements in human nutrition and health: World Health Organization, Geneva, Switzerland, $361 \mathrm{p}$. 
Prepared by the Helena Publishing Service Center

For additional information contact:

Director, Colorado Water Science Center

U.S. Geological Survey

Box 25046, MS 415

Denver Federal Center

Lakewood, Colorado 80225

(303) 236-5900

http://co.water.usgs.gov/ 


\section{$\frac{\mathbb{2}}{3}$}

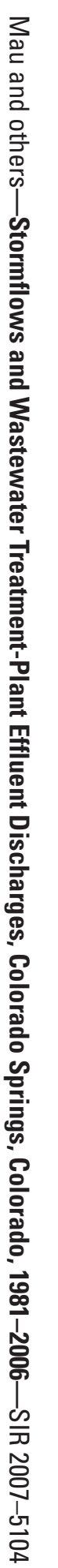

ISBN 978-1-4173-1877-9

8 Printed on recycled paper 